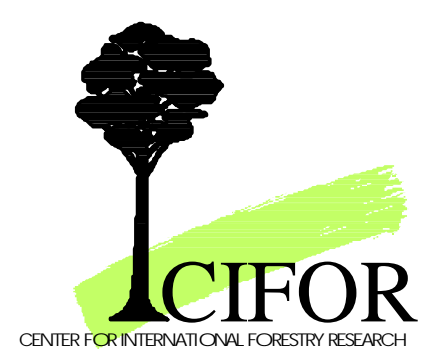

\title{
Rational Exploitations: Economic Criteria \& Indicators for Sustainable Management of Tropical Forests
}

Jack Ruitenbeek and Cynthia Cartier

CENTER FOR INTERNATIONAL FORESTRY RESEARCH

Office address: Jalan CIFOR, Situ Gede, Sindangbarang, Bogor 16680, Indonesia Mailing address: P.O. Box 6596 JKPWB, Jakarta 10065, Indonesia

Tel.: +62 (251) 622622; Fax: +62 (251) 622100

E-mail: cifor@cgiar.org

Website: http://www.cgiar.org/cifor 


\section{Contents}

Summary 1

Part 1: Of Trees and Trade: An Introduction 5

$\begin{array}{ll}\text { Part 2: Of Economists and Economics: A Brief History } & 7\end{array}$

Part 3: From Stand to State: A Framework 9

Institutional Lessons $\quad 9$

Policy Lessons $\quad 10$

$\begin{array}{ll}\text { Summary } & 12\end{array}$

Part 4: Of Production and Profits: Issues in Efficiency 13

$\begin{array}{ll}\text { Profitability Indices } & 13\end{array}$

$\begin{array}{ll}\text { Rent } & 14\end{array}$

Waste and Losses $\quad 14$

$\begin{array}{ll}\text { Lessons } & 14\end{array}$

Part 5: Of Privilege and Poverty: Issues in Equity 15

Employment 15

$\begin{array}{ll}\text { Taxation } & 16\end{array}$

$\begin{array}{ll}\text { Income Distribution } & 16\end{array}$

$\begin{array}{ll}\text { Lessons } & 16\end{array}$

Part 6: Of Plans and Paradise: Issues In Sustainability 17

$\begin{array}{ll}\text { Planning } & 17\end{array}$

$\begin{array}{ll}\text { Externalities and Valuation } & 18\end{array}$

$\begin{array}{ll}\text { Natural Capital } & 18\end{array}$

$\begin{array}{ll}\text { Lessons } & 18\end{array}$

Part 7: Good Forests, Good Policies, Good Institutions \& Good Luck:

A Recipe for Sustainability $\quad 19$

Risk and Uncertainty 19

$\begin{array}{ll}\text { Tenure } & 20\end{array}$

Corruption 20

$\begin{array}{ll}\text { Summary } & 21\end{array}$

Part 8: Measure for Measure: A Review 23

Lessons from Elsewhere $\quad 23$

Seven Sets $\quad 24$

The CIFOR Set $\quad 24$

Summary $\quad 25$

Part 9: Criteria and Indicators: A Proposal 27

$\begin{array}{ll}\text { A Negative List } & 27\end{array}$

$\begin{array}{ll}\text { A Positive List } & 27\end{array}$

$\begin{array}{ll}\text { Closing Remarks } & 28\end{array}$

$\begin{array}{ll}\text { Notes } & 31\end{array}$

$\begin{array}{ll}\text { Annex A: Policy Links } & 37\end{array}$

Annex B: Review of Economic Criteria \& Indicators 45

Acknowledgement 53

About the Authors 53 


\section{Tables}

Table 1. Recommended Economic Principles for Sustainable Forest Management

$\begin{array}{lll}\text { Table 2. What Have Economists Worried About? } & 7\end{array}$

$\begin{array}{lll}\text { Table 3. Attributes of Forest Fee Structures } & 11\end{array}$

Table 4. Assessment of CIFOR Criteria \& Indicators 25

$\begin{array}{lll}\text { Table 5. Recommended Criteria \& Indicators } & 29\end{array}$

Table A.1. Economic Policy Links to Forest Management - Forest Sector 42

Table A.2. Economic Policy Links to Forest Management - Non-Forest Sector Policies

Table B.1. Economic Dimensions of C\&I Set - ITTO 47

Table B.2. Economic Dimensions of C\&I Set - African Timber Organization 48

Table B.3. Economic Dimensions of C\&I Set - Tarapoto Proposal 49

Table B.4. Economic Dimensions of C\&I Set - Iniative Tropenwald 50

Table B.5. Economic Dimensions of C\&I Set - Woodmark 52

Table B.6. Economic Dimensions of C\&I Set - SmartWood 53

Table B.7. Economic Dimensions of C\&I Set - Lembaga Ekolabel Indonesia 54 


\title{
Rational Exploitations: Economic Criteria \& Indicators for Sustainable Management of Tropical Forests
}

\author{
Jack Ruitenbeek and Cynthia Cartier
}

\begin{abstract}
Summary
"TO HIM WHO LOOKS UPON the world rationally, the world in its turn presents a rational aspect. The relation is mutual." - Georg Hegel, German philosopher, 1837

"RATIONALists aRE ADMIRABLE BeINGS, RATIONALISM is a hideous monster when it claims for itself omnipotence. I plead not for the suppression of reason, but for a due recognition of that in us which sanctifies reason."
\end{abstract}

- Mohandas K. Gandhi, Indian political, spiritual leader, 1926

$\boldsymbol{H}^{\mathrm{cos}}$ CONOMISTS GENERALLY ASSUME that people are 'rational', and that the same applies to the various organizations, corporations, or clubs that people form. Profit-seeking by companies, purchasing choices by consumers, planting and harvesting decisions by farmers, and entire structures of government taxation and spending can often be described as 'rational'; the outcomes in all of these instances seem to serve someone's self-interest.

But the economist's understanding of 'rationality' is often at odds with what others might regard as rational. There seems, from a common sense perspective, to be little 'rationality' in depleting the ozone layer, or in fouling the oceans, or in irreversibly cutting down or otherwise converting the world's tropical forests. Yet all of these are occurring, presumably as the consequence of a myriad of 'rational' actions by consumers, producers and governments around the world. One might understandably speculate either that people are irrational, or that economists lack common sense. Such conjectures would undoubtedly generate lively debate, but they are unlikely to resolve global problems or to provide specific policy guidance.

This paper has a very specific objective in mind: to develop economic criteria and indicators that relate to the sustainable management of tropical forests. In 1994, the Center for International Forestry Research (CIFOR) commenced a work program that would develop a comprehensive set of criteria and indicators $(C \& I)$; this set would help inform governments, producers and consumers about conditions in individual tropical forest stands. Work has already been completed in the areas of biodiversity indicators, social indicators, and planning and legal indicators, among others; CIFOR has itselffield tested a slate of indicators that were selected from an "experts' wish list" of some 1100 indicators. This paper complements the current work program by covering the economic dimensions and issues associated with C\&I design.
The topics that must be covered to define economic indicators - especially those that are readily operationalized - are quite varied and broad. Existing C\&I efforts, however, do not always reflect the breadth of experience that exists in the broader economic literature: much can still be learned from the more general economics literature. A key purpose of this paper, therefore, is to synthesize some of this 'non-C\&I' literature, with a view to distilling some key lessons that are of relevance to $C \& I$ design within the forestry sector. In doing this, the paper covers topics ranging from economic history and the role that 'rationality' has played in economic decision-making, to modern procedures of resource valuation, to issues of uncertainty, taxation and wealth distribution. Findings in all of these areas, in the end, guide the selection of a recommended set of criteria and indicators.

LESSON 1 - Remain rational, but look beyond simple 'economic efficiency' to consider 'economic equity' and 'economic sustainability'

A somewhat mistaken perception of an 'economic approach' to resource management is that it always includes some form of valuation or monetization. Recent work by a group of ecological economists, for example, concluded that the services provided by the world's tropical forests had an economic value of US\$2 trillion. While such valuations draw attention to the importance offorests, they are just one tool in a much larger tool-kit of methods and experience. Monetization is a factor in some of these tools, but it is certainly not the common element that binds these methods together.

What is common to most economic methods is the underlying assumption of 'rationality': the idea that decisions are made in the interests of some definable individual or group, and that such decisions are made in 
some consistent fashion. Historically, economic rationality tended to focus on ideas of economic efficiency. Rational choices were those that minimized costs, maximized profits, or brought the greatest good to the greatest number of people. Forests were 'rationally' clear-cut to the profit of colonial powers: the timber built navies and the profits filled government coffers.

With time, economic investigation also started to pay greater attention to concerns of equity or distribution. In a liberal society, it now also became rational to worry about the poor or disenfranchised: progressive taxation, job creation to help the unemployed, and subsidized healthcare and education all are instruments of economic policies that address this equity dimension. Rationality had been expanded to included a degree of altruism towards our neighbors, or to those less fortunate. In some countries, for example, forest sector subsidies supporting local industries became an instrument of economic policy.

More recently, however, the idea of 'economic sustainability' has entered the picture, and economists have brought all of their tools and methods of 'rationality' to bear on this issue as well. While sustainability means different things to different people, it generally teaches us to pay more attention to the needs of future generations, and to the longer-term social and environmental ramifications of current production and consumption decisions. The economic rationality net has thus been cast further: it now encompasses not only concerns of efficiency and equity, but also of ecological resilience and of intergenerational rights and obligations. Most notably, many of the 'sustainability' issues arise at a global scale, and the economic challenge in many sectors has been to find mechanisms that can work at a local level. Forestry is no exception: it seems easy to point to cases of 'unsustainable forestry' but it is notoriously difficult to define or to identify 'sustainable forestry.'

In brief, there is more to economic inquiry than simple valuation. Economic inquiry, in a more complete sense, deals with rationality. Rationality, in this age, requires that we pay attention to efficiency, equity, and some of the finer elements of sustainability. In this exercise, it seems fair to say that any economic criteria and indicators of sustainable forest management would need to reflect these dimensions of efficiency, equity and sustainability: profits, people and paradise are all important.

\section{LESSON 2 - Keep your focus on the stand of trees, but also look beyond to the economic policies and institutions that affect the stand}

Any good forester will tell you that forest stand management can be as much of an art as it is a science. No two stands are alike, and the long-management cycles of a tropical forest stand require astute attention to numerous details that demand broad experience and technical excellence. Much of this experience can only be shared through publication of guidelines, handbooks, and forest management models, and through constant training and re-training. From this has arisen a vast literature on forest management, forestry economics, rapid rural appraisal, and forest resource measurement. Of this, $99 \%$ focuses on the forest stand - or forest management unit (FMU) - and most, if not all, has something to say about forestry economics. The forest stand has clearly been at center stage.

But this zealous predilection for micro-managing the forest has often come at the neglect of other equally important matters: forest economic policy and the institutions that govern forest use. Even with all of the tools of good forest stand management at our fingertips, circumstances may go terribly awry if we neglect these policies and institutions.

Think of sound economic management as a recipe: a recipe with ingredients relating to the forest itself, and the surrounding policies and institutions. Each of these three - the stand, the economic policy environment, and the institutions - is a potential 'intervention point' for promoting sustainable management. For sustainability to be achieved, one needs to get the interventions right in all three areas: bad policy distortions or institutions can undo whatever goes on at the stand. Policies can be specific to the forestry sector (e.g., mechanisms for capturing economic rents), or to other sectors (e.g., agriculture, energy or tourism).

Also, from a C\&I perspective, one should think of policy and institutional indicators as early warning signals. One might justifiably remark, "so what if there are bad policies? Sooner or later these will be reflected at the stand and we can detect conditions there." In principle, this is true. But this detection comes after the fact. In hindsight, most analysts now attribute a good share of Amazonia's deforestation to inappropriate agricultural and export policies. Had these connections been made before the fact, some of these forests might still be standing. If we can detect policy or institutional distortions, we may be able to take appropriate measures at the stand level to ensure sustainable management.

\section{LESSON 3 - Economic sustainability means paying as much attention to stocks and assets as we have traditionally paid to flows and income}

Economists have spent considerable effort of late discussing the topic of 'natural capital.' This was largely brought on by the common criticism that many well-known measures of 'income' - such as GNP - do not reflect capital depletion. If we clear-cut a forest, all of the money we make from it that year is treated as a positive contribution to GNP. 
Similarly, money spent on fixing or preventing environmental damages, such as for combating man-made fires, is counted as an addition to GNP. In response to such aberrations, the United Nations Statistical Office (UNSO) now recommends that countries also attempt to keep 'natural resource accounts' that reflect issues such as capital depletion and environmental impacts.

Approximately half a dozen accounting methods have been identified, and various countries are currently testing different approaches. Forestry is a key sector that is being included in most experiments; and techniques are being developed for different application scales. In India, pathbreaking resource accounting methods are being applied to small-scale community woodlots of 40 hectares, while in Indonesia resource accounting methods have focused on the forest estate at the provincial level.

While there remain a substantial number of methodological and practical issues to be resolved in the 'natural capital accounting field', the basic rationale for it is straightforward. Sir John Hicks, in 1946, stated that "The purpose of income in calculations in practical affairs is to give people an indication of the amount which they can consume without impoverishing themselves. ... we ought to define a man's income as the maximum value which he can consume during a week, and still expect to be as well off at the end of the week as he was at the beginning." In other words, income is only income if the capital generating it remains intact. In this context, most commentators have agreed that we must pay greater attention to natural capital stocks.

In the forestry sector, we have historically concentrated on income flows from merchantable timber. Largely this is because society never bumped into the forests' limits: we were working in a 'frontier economy' where the stocks seemed, for all intents, to be limitless. But now we have bumped into these limits and, appropriately, we have to start paying greater attention to stocks, and to the goods and services (other than timber production) that we might lose if those stocks disappear. Specifically, in C\&I design, we should (i) continue to pay attention to the flow of wood products; (ii) also pay attention to the stock (quantity and condition) of remaining forest; and, (iii) pay attention to the flow of (non-timber) goods and services from the forest.

\section{LESSON 4 - Be prepared for surprises, and exercise precaution in forest management}

Even if in a given instance we seem to have a healthy and vibrant forest, sensible policies, and competent institutions, we may end up - in the long-term - with unsustainable forestry. Some might call this bad luck. But why does this happen, and what can one do about it?

In brief, it has to do with 'complexity'. Literature in the area of economic sustainability is paying greater heed to complexity. A complex adaptive system is capable of reorganizing and self-organizing itself, in response to random external shocks. Large economic systems, living organisms, neurological networks and ecosystems are all examples of complex systems. Any forest ecosystem, coupled in turn to a variety of political, institutional and social structures, is such a system. A common feature of complex systems is that they generate 'surprises'.

One lesson from complexity theory is that unquantifiable uncertainty is much more pervasive than was ever previously thought. Small initial shocks can, through various feedback mechanisms, have substantial impacts. Arbitrary factors such as political corruption, war, social unrest, or changes in international markets can all undermine even the best laid out plans for sustainable forest management. For decision-makers, addressing such uncertainty is a challenge.

The most common economic policy prescription in the face of uncertainty is to invoke the 'precautionary principle'. Criteria and indicators may have a number of roles in implementing this principle. Guidelines for indicators or verifiers can be established at safe thresholds that, for example, prevent clear-cuts from occurring. Criteria can be established for 'adaptive' management plans that are capable of addressing sudden anticipated shocks. Indicators can monitor the establishment of 'reserve funds' to deal with unanticipated emergencies, such as fire damage. While the specific criteria and indicators are likely to differ substantially from country to country or even site to site, the lesson is clear: plan for the unexpected.

LESSON 5 - Keep the criteria \& indicator design simple to permit an easy assessment of tradeoffs

Work in economic indicators in forestry and related renewable resource sectors has generated some important conclusions about the general design of indicators. Many of the earlier efforts in indicator implementation have been abandoned simply because they were too costly to implement or lacked reliability when attempts were made to interpret them. In Canada, a recent two year economic audit of 'ecosystem based forestry and watershed indicators' by Environment Canada found that $83 \%$ of them were not suitable for statistically valid economic interpretation. Similar findings have recently been noted in some European countries. Given these constraints in industrialized countries, any efforts in designing C\&I for economic monitoring of forestry in developing countries must be based on the following notion: keep it simple.

Implementation of economic criteria and indicators raises another issue: diagnostic capability. Most of economic science prides itself (probably mistakenly) in being nonnormative when it comes to measurement and analysis: economists will cheerfully tell you what may or may not 
happen, but pass no judgment as to whether such outcomes are 'good' or 'bad'. Many economic indicators exhibit such characteristics: economists might generally all agree that GNP is an important indicator, but disagree over whether increases in it are inherently good or bad. The diagnostic capabilities of a given economic measurement often depend on subsequent analyses that concurrently take into account yet other economic measurements. This can be a nuisance to someone managing a forest stand, simply trying to decide whether they are doing a good job. For this reason, it seems fair that, to whatever extent possible, economic indicators at the FMU level should have some stand-alone diagnostic capabilities. This requires, again, that such indicators be kept relatively simple.

The implications of this translate into two operational lessons: (i) keep the list relatively short; and, (ii) keep individual criteria or indicators to something that monitors a single goal (e.g., efficiency, equity, maintenance offorest asset) or a single intervention point (e.g., forest stand, policy, or institution). Criteria and indicators are certainly available that may apparently address numerous objectives (these have at times been called 'multi-telling'), but such indicators are difficult to interpret and implement at a stand level (although they may be more useful at a higher level of government policy).

\section{Recommended Criteria and Indicators}

The above lessons suggest a general set of economic $C \& I$ for forest management. In developing this set, it is clear that different indicators may be used in some countries, while still meeting the underlying criteria. There is therefore some level of substitutability available. Having said that, however, there are some potential indicators that have been commonly used, or are becoming commonly advocated, that we believe are inappropriate because they are frequently misinterpreted, are methodologically unsound, are inadequately developed, or are too costly to implement. We therefore create both a 'negative list' of indicators, and a 'positive list' of recommended C\&I that can address the issues and concerns raised in this paper.

Some attributes of the 'positive list' are summarized in Table 1. It reflects the broader needs to address efficiency, equity, sustainability and a precautionary stance in FMU management. What is perhaps notable about this list is that it does not necessarily involve a lot of economic calculations relating to pricing and values: many $C \& I$ that are of economic relevance are simply physical measures.

Within the 'negative list,' we include: (i) use of internal rate of return, which is a frequently used but inaccurate measure of economic efficiency; (ii) valuation of biodiversity, carbon sequestration, and certain ecological functions that are equally well captured by a simple physical accounting of the forest biomass; and, (iii) use of complex economic indices and coefficients to characterize income distribution concerns.

\section{Conclusion}

If one is of the mindset that the world is fundamentally chaotic and irrational, then the discipline of economics probably has little to offer. But if one accepts the notion that there is some method to the apparent madness of individuals, governments and organizations, then economic inquiry does have some contributions to make.

In this exercise, we argue that economic criteria and indicators of sustainable forest management should reflect the dimensions of efficiency, equity and sustainability, and need to look beyond the forest stand to institutional and policy issues. If we let such criteria inform our decisions, we may yet end up with exploitation of the forests. It would, however, be rational exploitation; rational exploitation reflecting an enlightened self-interest that captures the broader global needs of current and future generations.

\begin{tabular}{|l|l|}
\hline $\begin{array}{l}\text { Table 1 } \\
\text { Recommended Economic Principles for Sustainable Forest Management }\end{array}$ \\
\hline Principle & Examples of Criteria and Indicators \\
\hline Forest management is socially efficient. & $\begin{array}{l}\text { Efficient timber extraction methods are applied. } \\
\text { Sustainable harvesting of non-timber forest products occurs. } \\
\text { Management generates positive economic rent. }\end{array}$ \\
\hline Intragenerational equity is enhanced. & $\begin{array}{l}\text { Involvement of local population in forest management. } \\
\text { Equitable positive rent share to all participants. } \\
\text { Transparent allocation of concessions. }\end{array}$ \\
\hline Forest estate and forest use options are maintained. & $\begin{array}{l}\text { Forest migration pressure is minimized. } \\
\text { Non-forest policies do not affect forest management. } \\
\text { Existence of non-confiscatory land use policies. }\end{array}$ \\
\hline Precautionary measures promote system resilience. & $\begin{array}{l}\text { Anti-corruption measures in place. } \\
\text { Existence of broad-based adaptive management plans. } \\
\text { Establishment of effective buffer zones. }\end{array}$ \\
\hline Note: See Table 5 in text for complete list of recommended criteria and indicators.
\end{tabular}




\section{PART 1}

\section{Of Trees and Trade: An Introduction}

"VALUE IS THE MOST INVINCIBLE and impalpable of ghosts, and comes and goes unthought of while the visible and dense matter remains as it was."

- W. Stanley Jevons, British economist, logician, 1884

"BouRgeois SOCIETY IS INFECTED by monomania: the monomania of accounting. For it, the only thing that has value is what can be counted in francs and centimes. It never hesitates to sacrifice human life to figures which look well on paper, such as national budgets or industrial balance sheets."

- Simone Weil, French philosopher, mystic, 1937

$\mathrm{E}$ CONOMISTS KNOW THE PRICE of everything and the value of nothing." This adaptation of the infamous turn-of-the-century quote by playwright Oscar Wilde may well be the reason why forests around the world are succumbing to the feller's axe and the farmer's torch. Any undergraduate student in forestry economics can 'prove' that it makes economic sense to clear-cut a forest if its rate of growth in value is less than the rate of return on money invested elsewhere. Have you kept track of the stock markets? Recent anomalies aside, forests would need to grow at over $10 \%$ a year to keep pace with long-term returns elsewhere. That represents a doubling in volume about every seven years. Few forests grow that quickly. The axe and the torch seem like a rational choice.

But something is clearly wrong with this picture. The 'proof' relies a lot on what happens to 'price', and ignores so many other things. It ignores the medicinal products in the forest. It ignores the local livelihoods dependent on the forest. It ignores the soils and watersheds that the forest stand protects. It ignores the carbon sequestered in the forest biomass. It ignores, one might argue, everything of true value.

Fixing this situation may seem straightforward. We need simply to alter our assumptions, by casting our analytical net somewhat wider to capture this broader range of values, and then train the next wave of undergraduate students appropriately. Typically, in the economist's world, this has led for more calls to put prices and values on goods and services that heretofore had no market. But the general problem is much more complex than this; and solutions are still not readily at hand. This paper explores some of the issues that cause economically sustainable forest management to remain so elusive.
The impetus behind this effort stems from CIFOR's ongoing project on "Assessing the Sustainability of Forest Management: Testing Criteria and Indicators". The project concentrates on the local or forest management unit level and seeks to identify C\&I for sustainable forest management. Based on an analyses of C\&I development activities at sites in Germany, Indonesia, Côte d'Ivoire, Brazil, Austria and Cameroon, it was determined that the economic dimensions of previous efforts had not been addressed comprehensively. As a first step towards addressing the issue of C\&I for economic impacts, this paper explores some of the basic issues, pitfalls, opportunities and difficulties in trying to develop C\&I for economic impacts at the FMU level.

In principle, the economic issues that might be addressed are manifold. How does one take into account currency fluctuations, such as those experienced of late in Asia? How do we address intangible benefits? What role should local employment play? Do conventional measures of rates of return or benefit-cost ratios have any relevance to sustainable forest management?

It is clear that this is potentially a big canvas, and it is not the purpose of this paper to cover all dimensions of the economic problem. Indeed, an indicator list that does address every problem is likely to become unmanageable. The C\&I set derived in this work focuses on what is feasible within a short assessment period by non-experts. Examples for these kind of assessments are certification inspections, inspections by regulatory agencies or by donor agencies.

The approach taken in this paper involves a dialectic that may appear to work backwards from conventional discussions on the topic. Usually, one will find a 'review' 
close to the beginning. In this paper, if you are interested in just a review of indicators, please turn to our penultimate chapter: Part 8 . All of the previous chapters set the stage for this; we find it necessary to present an understanding of some of the 'economic issues' before we can even begin to discuss or critique the individual C\&I sets. Parts 2 and 3 therefore commence with an historical discussion of economic efficiency, equity and sustainability (we call these 'goals'), and an elaboration of a framework that involves the potential role of the forest stand, economic policies, and institutions (we call these 'intervention points'). Parts 4 to 6 investigate more specific issues in efficiency, equity and sustainability, and Part 7 provides a forum for exploring some of the more eclectic issues associated with precautionary management. Finally, we develop some measurable or monitorable C\&I in our concluding chapter.

One might, however, justifiably ask, "Why measure anything?" The most forthright answer to this question lies in the complex world of the international timber trade. Earnings from forest product trade are a major share of export revenues for many developing countries: ITTO producer exports of tropical timber products were worth $\$ 11.5$ billion in 1995, 79\% originating in Asia. Opponents of the trade have blamed it for deforestation, for neo-colonial exploitation of developing countries, for disenfranchising the poor and landless, for loss of sovereignty to stateless transnational corporations, and for lining the pockets of bureaucrats, politicians, and entrepreneurs through institutionalized corruption or incompetence. Proponents of the trade see it as a powerful engine of economic growth and development: one that creates jobs, improves international competitiveness, and enhances the lifestyle of those consuming the wide range of products we enjoy today.

The debate is at times engaged along very moralistic and emotional grounds, while at times it becomes a very pedantic exercise in accounting. In an effort to cut through both the rhetoric and the pedantry, and to bring objectivity to the debate, timber certification is held up as one practical mechanism that will help inform all stakeholders. Development of C\&I plays a key role in certification.

Before we discuss economic C\&I, therefore, we find that it is fair to make some comments on some of the economic implications of certification itself. The implementation of a certification scheme for tropical timber from sustainable forest management will have implications for the international supply and demand of tropical timber products.
Some consumers boycott tropical timber because of increased awareness of unsustainable forest management practices. In light of the substitutes that have emerged, will these consumers buy tropical timber again if certification and labeling can assure them that tropical forests are being managed sustainably? If so, what price will they be willing to pay for certification, given that it will undoubtedly carry a supply premium (at least in the short run). What will be the net effect on tropical timber demand? Will consumers, through demand for certified products, be able to promote sustainable forest management effectively? Currently, we have few complete answers to these important economic questions.

Also, there is a danger that a certification scheme will become a non-tariff trade barrier and undermine efforts to liberalize and economize global trade. The scheme is currently voluntary, but it could become, in effect, a compulsory trade requirement. The scheme could also favor industrialized countries where forest management practices are perhaps closer to being certifiably sustainable. The scheme would likely also favor government-owned and large private forests, at the expense of small-scale forests. The unit costs of certification are smaller for larger operations; and given their market share, the large-scale forest operation also stands to benefit most from certification. Certification, itself, may generate new inefficiencies and inequities that are different, but perhaps not an improvement on current conditions.

Finally, for a certification scheme to have any impact on trade, it must be credible. The process of certification must be transparent with enough checks and balances to keep it from being abused, discredited, or the subject of ongoing corruption. International cooperation will be required to develop, harmonize, and implement a credible certification scheme. A key issue in the development stage of the certification system is reaching agreement on the sustainability $\mathrm{C} \& \mathrm{I}$ which comprise the system.

Demand impacts, supply costs, production and trade patterns are all economic issues pertaining to the implementation of a certification system for tropical timber products. Resolving such issues will not be easy. Certification should not be regarded as the panacea that will address the ills of the tropical timber trade. Similarly, developing a good set of criteria and indicators should not be seen as the panacea for establishing an implementable certification system. Nonetheless, these do seem like sensible places to start. 


\section{PART 2}

\section{Of Economists and Economics: A Brief History}

"IF ECONOMISTS COULD MANAGE to get themselves thought of as humble, competent people on a level with dentists, that would be splendid."

- John Maynard Keynes, British economist, 1931

"IF ECONOMISTS WERE DOCTORS, they would today be mired in malpractice suits."

- John Ralston Saul, Canadian author, 1995

Se ELF-INTEREST IS A POWERFUL incentive. To the noneconomist, it may seem that economists have applied that lesson with vigor to the role they have in decisionmaking. Economists' opinions are arguably the most sought after, most despised, most heeded, most ignored, or most blamed in the corridors of corporate and public decision-making. Any review of the literature will show that, on almost any topic, some economist somewhere will have had something to say about it. Economists may well gain or lose respect with each turn of the tide, but they seldom seem to lose their jobs.

From an economist's perspective, however, 'selfinterest' has an entirely different connotation: selfinterest is the basis of rationality, and rationality is the basis of economic behavior. Economic thought and analysis through the ages has focused on different interpretations of rationality. Understanding this progression can give us some useful insights into how economic issues (including indicator design) can be viewed.
Table 2 summarizes, in a somewhat stylized fashion, this progress of thought and attention. First-year university students are taught that economic science deals with the study of 'scarce' resources and, more normatively, the allocation of such resources to various uses. Food is scarce. Housing is scarce. Energy is scarce. Labor is scarce. All are economic goods or services, whether priced or not. Efficient use of these goods is the first stage of behaving rationally. Economic models showed how to allocate these goods and services to their best use. Measures of economic efficiency became gauges of whether this allocation was being done successfully. Profits or costs per unit became measures of profitability or cost-effectiveness. As risk management became part of rational economic behavior, various methods and measures of risk analysis also developed.

But as economic and social systems became more complex, economists extended the concept of rationality into new realms. By the mid-20th century, taxation

\begin{tabular}{|c|c|c|c|}
\hline & Objective & Types of Concerns & Methods \& Measures \\
\hline $\begin{array}{l}\text { Economic Efficiency } \\
\text { (19th \& 20th century) }\end{array}$ & $\begin{array}{r}\text { To allocate scarce } \\
\text { resources to their best } \\
\text { use }\end{array}$ & $\begin{array}{r}\text { Profitability } \\
\text { Cost Minimization } \\
\text { Risk Management } \\
\text { Waste Reduction }\end{array}$ & $\begin{array}{r}\text { Cost - Benefit Analysis } \\
\text { Rates of Return } \\
\text { Monte Carlo Risk Analysis }\end{array}$ \\
\hline $\begin{array}{l}\text { Economic Equity } \\
\text { (1950s - present) }\end{array}$ & $\begin{array}{r}\text { To permit fair } \\
\text { participation in economic } \\
\text { production and } \\
\text { consumption }\end{array}$ & $\begin{array}{r}\text { Jobs } \\
\text { Taxation } \\
\text { Poverty } \\
\text { Gender }\end{array}$ & $\begin{array}{r}\text { Economic Impact Analysis } \\
\text { Rent Share Analysis } \\
\text { Gini Coefficients } \\
\text { Women's Income Assessments }\end{array}$ \\
\hline $\begin{array}{l}\text { Economic Sustainability } \\
\text { (1970s - present) }\end{array}$ & $\begin{array}{r}\text { To respect the economic } \\
\text { needs of future } \\
\text { generations through } \\
\text { maintaining production } \\
\text { and consumption options }\end{array}$ & $\begin{array}{r}\text { Global \& Local Environment } \\
\text { Uncertainty } \\
\text { Irreversibility } \\
\text { External Impacts }\end{array}$ & $\begin{array}{r}\text { Environmental Economic Analysis } \\
\text { Discount Rate Adjustments } \\
\text { Precautionary Measures } \\
\text { Valuation of Externalities }\end{array}$ \\
\hline
\end{tabular}


(which was originally developed to fund the war effort) and job creation (which was a key aspect of recovering from the Great Depression) became key components of economic policy. Distribution of entitlements, whether to work or to money, was an active part of economic inquiry. Liberalization soon expanded the 'equity' dimension further to consider the fate of the economically disenfranchised: most notably of the poor and of women.

Economic analysis again offered up a host of indicators to address such equity issues. Employment impacts, taxation rates, income distribution indices such as the 'Gini' coefficient, or simple income shares, became standard measures of 'fairness'. All of these issues, however, were primarily concerned with the distribution and allocation of goods and services within the society of the day; we call this 'intragenerational' equity. In this context, a 'rational' society had to pay attention to who got what; doing otherwise might foment social unrest or undermine society's altruistic ideals.

Increased awareness of local and global environmental degradation spawned the more recent focus on 'economic sustainability.' The field of environmental economics blossomed during the early 1970s, primarily because a number of American regulatory authorities required such assessments while reviewing the 'public interest' of everything from pipeline projects to forestry policies. In addition, however, the inquiry surrounding economic sustainability expanded to address issues such as uncertainty (as opposed to risk), irreversibility, and 'externalities.' Externalities arise when someone's decision to produce or consume something has impacts on an unrelated party. Pollution is the classic example of a negative externality. While sustainability encompasses many issues, the one element that most of these issues have in common is that of a concern for 'future generations'. In this context, a rational society pays attention to the needs of its children and of its children's children.

Within this progression from efficiency to equity to sustainability, a few observations are relevant.

First, many economic policy instruments have coevolved along this same route. The institution of property rights is such an example. One of the earlier reasons for reforming property rights was to improve efficiency: private ownership reforms replaced the open-access 'rule of capture' that existed historically. Subsequently, property right reforms addressed equity and distributional issues, especially in developing countries where a key role of such reforms was to improve the economic fortune of the poor. More recently, economists are looking at ways of using property rights to managed previously untraded goods, including pollution. This all implies that it may not be necessary to reinvent the wheel when it comes to economic sustainability indicators: many may be adapted based on previous measures.

Second, the long history of economic analysis has generated a fair amount of debate, among economists and others, over the interpretation of certain measures. We may all agree that employment or GNP statistics are important, but we may not agree why they are important, or whether increases or decreases in these measures are 'good' or 'bad.' Many people are puzzled, for example, that stock markets go up when the economic reports show increases in unemployment. This seems counterintuitive: why should economic stagnation (unemployment) be seen as a positive signal to investors? The answer, in this case, lies in a market consensus that higher unemployment means fewer wage demands, which means less inflation, which means lower interest rates, which means improved company profitability, which warrants higher stock prices. Whether one regards this sequence of logic as 'rational' is immaterial; the point is that a single economic indicator is generally regarded as meaningless unless it is taken within a context of other information. In short, one will be hard-pressed to find single measures that unambiguously diagnose a condition.

Finally, in economics, as in many things, history repeats itself. To address equity issues, many major economic reforms were originally rooted in some form of 'efficiency' analysis. Economists could show, for example, that it cost more to feed and house a slave and his family than the slave in fact produced in the field. These were classic cost-benefit analyses where the benefits fell short of the costs. In response to high injury rates and fatalities, economists writing during the industrial revolution frequently drew up accounts demonstrating that it was cheaper for factories to install railings and safety features than it was to hire and train new workers. These were classic cost-effectiveness analyses, aimed at cost minimization. Until relatively recently, the World Bank conducted cost-benefit analyses of its education investments to convince local governments that education was a sound economic investment. In each of these cases, the practice of the day was shown to be 'inefficient.'

As with these equity issues, so with the sustainability issues. Economists engaged in the 'clearcutting debate' find themselves attacking the problem differently. A few are saying that clearcutting is "not right." Some are saying that it is "not fair to future generations." But most, through a preponderance of valuation and similar studies, still argue simply that it is "economically inefficient." But all of these goals - efficiency, equity, and sustainability - are part and parcel of the same broad 'rationality' picture. 


\section{PART 3}

\section{From Stand to State: A Framework}

“Government has no other End but the preservation of Property."

- John Locke, English philosopher, 1681

"THE WHOLE HISTORY OF CIVILISATION is strewn with creeds and institutions which were invaluable at first, and deadly afterwards."

$\mathrm{I}$ MAGINE YOURSELF IN A CONFERENCE room in the tropics. All of the windows are open, but there are few cooling breezes. The air conditioner is laboring excessively on a 'Low' setting. The air is humid and oppressively hot. What would you do? A: Turn the air conditioner to 'High', B: Call a mechanic, C: Close the windows, or D: All of the above.

Worded thus, the answer seems obvious. One should attack this particular problem from all fronts: improve the efficiency of the air conditioner, get help to look after the air conditioner, and close the windows so that efforts are not wasted.

But now imagine the air conditioner to be the forest stand, the mechanic to be the institutions that govern the use and management of the stand, and each window in the room to be a different economic policy that is somehow distorting the effectiveness of the stand. The environment is hot and clearly unsustainable. What would you do?

Historically, in this forestry example, countries have tended to focus on the forest stand, ignoring the institutions and policies that surrounded it. And, not surprisingly, even with some of the best forestry expertise brought to bear on looking after the stand, unsustainable forestry persisted. Two decades of economic analysis have demonstrated that ignoring economic policies will inevitably undermine the forest. More recent findings relating to institutional capacity draw similar conclusions. Examples to support these assertions abound, and numerous lessons can be drawn from these examples.

\section{Institutional Lessons}

- Revenue generating institutions can undermine stand management. In Cambodia, the export of logs is banned. As a result, and given the regional demand for
Cambodian wood (from Thailand and Vietnam), there is considerable illegal logging. Seizures of illegally cut logs account for about one-third of all illegal felling, and an Inter-Agency Commission is responsible for the disposal of the impounded logs. When seizures are close to domestic markets, logs are auctioned domestically; when seizures occur in remote areas, the logs are simply exported. In any case, the sale of illegal logs has become a valuable source of government revenue, thereby eroding incentive for the elimination of illegal logging.

- Centralized institutions require monitoring capacity. Over-centralized control can lead to administrative irregularities. A Honduran study found that when the authority for forest management became the exclusive prerogative of one office, the management plans for smaller forest units were compromised and increases in harvest volumes and industrial capacity were approved.

- Decentralized institutions require broader mandates. Small management units may pursue certain objectives at the expense of others. For example, forest management units in areas dominated by timber interests are likely to narrow their focus to timber extraction. Other forest products and uses are likely to be a secondary consideration. This problem will become especially pronounced if the management unit relies solely on revenue generated from timber rent capture.

- All institutions require accurate information. Most governments have failed to devote the adequate resources needed to manage their forest resource. Research and extension is lacking. Equipment and trained personnel are lacking. Policy analysis is sparse and development objectives are pursued in absence of forestry considerations. In many cases, the flora and fauna inventories are incomplete or nonexistent; the characteristics of the forest soils are unknown; the volume and value of harvested non-timber forest 
products (NTFPs) are unknown. Despite the enormous value of the forest, governments have not developed technical and economic expertise for gathering information about the forest and its varied products.

- Human resource development (HRD) is a recurrent constraint to institutional effectiveness. Natural management of a tropical moist forest requires more trained manpower than is required for artificial systems of regeneration. Junior technical positions often remain vacant because training is unavailable. In many cases, potential employees are not willing to work in the forest, given the harsh conditions and strict working hours. Training is further complicated because the required silviculture knowledge base is considerably large. Forest dwellers have the best field knowledge, but inadequate communication is often a problem. In some countries, basic literacy and numeracy problems are additional constraints to training local forest dwellers.

- Money isn't everything. National indicators of government expenditures on forestry management do not necessarily reflect the effectiveness of those expenditures. For example, many well-trained government foresters can not effectively manage the forest if their pattern of deployment is not consistent with the location of the forest resource. Such has been the case in Indonesia. The forestry service was weakened by lack of cooperation from other departments (agriculture and transmigration). But it was also ineffective because most of the personnel were stationed on Java, where the ratio was 1 forester/1,764 ha of forest; on the outer islands the ratio was 1 forester/471,000 ha.

\section{Policy Lessons}

An extensive review of the 'non-indicator' economic policy literature demonstrates the myriad policy linkages that exist between economic policy and stand management. ${ }^{1}$ Certain factors - such as insecure tenure and ineffective institutional management structures - are so pervasive that they further add to the problems caused by inappropriate policies.

- Non-forestry policies can generate significant distortions that affect the stand. These policies can either be macroeconomic in nature (e.g., exchange rate controls or export promotion policies) or sectoral (e.g, tourism, energy or agriculture policies). Some observers in Indonesia, for example, have noted that the extensive forest area lost to fire in Indonesia in 1997-1998 can be partially attributed to land-use conversion policies intended to increase agricultural output.
- Captured rent can be an indicator of well-designed forestry sector economic policies. In forestry, economic rent is most easily understood as the difference between product values and timber harvesting costs. A large number of schemes (royalties, fees, taxes, auctions, licenses) have been developed by governments to try to capture the rents, while still providing some economic incentives to harvest the forest. Each scheme will have its own peculiar impacts on forest management (see Table 3). For example, license fees are based on concession size and ideally differentiated according to accessibility and distance from markets, and stand quality, composition, and density. Accessible and high quality stands of primary species should entail a "high" license fee; inaccessible, lower quality stands of secondary species would command a "low" license fee. A well-designed, properly differentiated system of license fees would increase resource use efficiency because it could: (i) reduce over-exploitation of accessible stands; (ii) promote harvesting of lower quality, lower density stands; (iii) promote harvesting of secondary species; (iv) discourage the stockpiling of concessions; and, (v) encourage smaller, more manageable concessions. But license fees in most tropical timber producing countries are too low to achieve the above.

Ideally, forest policies as a whole will be established that capture a greater share of rents for the forest owner; correct underpricing; remove inefficiencies in harvesting and processing; and, offset adverse environmental effects of logging. In countries with sufficiently strong administrative capabilities and good forest information, evidence suggests that this can be achieved by moving to the use of timber auctions, heavier and differentiated license fees, and income taxation. They should move away from royalties; if a royalty is used to supplement rent capture, it should be applied to round log inputs. Countries with weak institutions and poor information should at least move to increased use of license fees to capture rent. Such fees can in turn be used to strengthen local management institutions and monitoring efforts.

- Policy distortions are often early warning signs of future management failures. It is much easier to identify evidence of unsustainable forestry than it is to identify

\footnotetext{
${ }^{1}$ Annex A provides a comprehensive review and assessment of policy linkages in the following policy areas: land tenure; forest management institutions; forest pricing; royalty structures and high-grading; royalties on processed wood products; harvesting rules; export taxes, log export bans; import duties; vertical integration; NTFP market failure; forest accessibility; agriculture; information; energy policies; exchange rates; population relocation; and, tourism.
} 


\begin{tabular}{|c|c|c|}
\hline \multicolumn{3}{|c|}{$\begin{array}{l}\text { Table } 3 \\
\text { Attributes of Forest Fee Structures }\end{array}$} \\
\hline Fee Type & Calculation Basis & Implications for Stand \\
\hline $\begin{array}{l}\text { Uniform Specific } \\
\text { Royalties }\end{array}$ & $\begin{array}{l}\text { - volume-based royalty } \\
\text { - levied on every cubic meter harvested } \\
\text { regardless of value; or levied on total costs } \\
\text { of extraction and marketing; or levied on } \\
\text { millsite processed products using a } \\
\text { conversion factor }\end{array}$ & $\begin{array}{l}\text { - simple to administer } \\
\text { - encourages high-grading in stand } \\
\text { - not indexed to inflation therefore wood likely } \\
\text { underpriced } \\
\text { - accessible and low extraction cost stands are } \\
\text { favored }\end{array}$ \\
\hline $\begin{array}{l}\text { Differentiated } \\
\text { Specific } \\
\text { Royalties }\end{array}$ & $\begin{array}{l}\text { - volume-based royalty differentiated by } \\
\text { species or location } \\
\text { - attempts to mimic ad valorem levy }\end{array}$ & $\begin{array}{l}\text { - simplicity of uniform levy lost } \\
\text { - substantial information requirements } \\
\text { - usually insufficient differentiation to prevent } \\
\text { high grading }\end{array}$ \\
\hline $\begin{array}{l}\text { Ad Valorem } \\
\text { Royalties }\end{array}$ & $\begin{array}{l}\text { - value-based royalty } \\
\text { - percentage levied on value is usually a flat- } \\
\text { rate across all species although it can be } \\
\text { differentiated to reflect different species } \\
\text { values and extraction costs }\end{array}$ & $\begin{array}{l}\text { - high-grading behavior is reduced } \\
\text { good potential to capture rent as it can be } \\
\text { easily adjusted to account for inflation and } \\
\text { extraction costs }\end{array}$ \\
\hline $\begin{array}{l}\text { Per-tree } \\
\text { Royalties } \\
\text { on Stems Taken }\end{array}$ & $\begin{array}{l}\text { - } \text { volume-based royalty } \\
\text { - levied on number of stems cut, verified by } \\
\text { counting stems taken or stumps remaining }\end{array}$ & $\begin{array}{l}\text { - simple to administer } \\
\text { if royalty is high enough and assessed on all } \\
\text { stems killed, it encourages: removal of large } \\
\text { stems; sparing of smaller stems; and efficient } \\
\text { use of cut stems }\end{array}$ \\
\hline $\begin{array}{l}\text { Per-Tree } \\
\text { Royalties on } \\
\text { Stand Volume }\end{array}$ & $\begin{array}{l}\text { - volume-based royalty } \\
\text { - assessed on the estimated volume of timber } \\
\text { in the stand } \\
\text { - royalty is paid on salable trees, whether or } \\
\text { not taken }\end{array}$ & $\begin{array}{l}\text { - good potential to capture stand rent and } \\
\text { discourage high-grading } \\
\text { - its success depends critically on quality of the } \\
\text { stand inventory }\end{array}$ \\
\hline $\begin{array}{l}\text { Royalties on } \\
\text { Processed } \\
\text { Timber }\end{array}$ & $\begin{array}{l}\text { value-based royalty on timber products } \\
\text { rate is based on presumed average } \\
\text { conversion rates from roundwood to sawn } \\
\text { timber or plywood output }\end{array}$ & $\begin{array}{l}\text { - administratively attractive because: there are } \\
\text { fewer processing plants than log dumps; it } \\
\text { captures illegal logs; it removes grading } \\
\text { problems } \\
\text { - discourages efficiency improvements } \\
\text { - benefits vertically integrated firms }\end{array}$ \\
\hline License Fees & $\begin{array}{l}\text { - generally, based on total concession area } \\
\text { and adjusted for accessibility } \\
\text { - fees may be imposed initially, annually or } \\
\text { both }\end{array}$ & $\begin{array}{l}\text { usually too low to capture rent or encourage } \\
\text { sustainable management } \\
\text { - if high enough and differentiated according to } \\
\text { stand density and accessibility, can: } \\
\text { discourage over exploitation; promote } \\
\text { harvesting of secondary and lower-grade } \\
\text { primary species; reduce concession } \\
\text { stockpiling; and encourage efficiency. }\end{array}$ \\
\hline $\begin{array}{l}\text { Reforestation } \\
\text { Fees }\end{array}$ & $\begin{array}{l}\text { fees are typically of three types: volume- } \\
\text { based or flat-rate ad valorem fees levied on } \\
\text { extracted timber; fees levied on processed } \\
\text { timber; or fees based on concession area }\end{array}$ & $\begin{array}{l}\text { differ little from royalty fees unless: fees are } \\
\text { refundable deposits conditional upon } \\
\text { reforestation effort; or, fees are used by } \\
\text { government to undertake reforestation; or } \\
\text { fees are high enough to induce reforestation } \\
\text { by concessionaires. }\end{array}$ \\
\hline
\end{tabular}


sustainable forestry. Quite often, by the time we identify unsustainable forestry, it is too late to do anything about it. Policy distortions can, therefore, serve as early warning indicators that future forestry operations may be unsustainable. In such cases, early detection provides opportunities either to correct the policy distortion, or to put in place targeted remedial measures at the stand level.

\section{Summary}

The forest stand, economic policies, and management institutions are all key intervention points in achieving sustainable forestry. Criteria and indicators should, where possible, identify which of these areas is being evaluated. A comprehensive set of criteria and indicators will address aspects of all three of these intervention points. 


\section{Of Production and Profits: Issues in Efficiency}

"The SOciety BASEd ON PROduction is only productive, not creative."

- Albert Camus, French-Algerian philosopher, author, 1951

“There is A Gigantic Difference between earning a great deal of money and being rich."

- Marlene Dietrich, German-born US film actor, 1962

$\mathrm{C}$ OST BENEFIT ANALYSIS WAS first used by a French engineer in the mid-nineteenth century to determine whether it made sense to build a bridge over a river in the town in which he lived. Many of his neighbors had been commuting daily to use a bridge some distance downstream to tend to their daily activities. He reasoned that the savings in time spent traveling might outweigh the costs involved in hiring the labor and buying the materials to build this bridge. He performed the mathematics and, to his presumed surprise, the project made sense. He published the results, built the bridge, and received the eternal gratitude of his neighbors.

The rest is history. Cost benefit analysis - and its variants such as financial feasibility analysis, rate of return analysis, and private or social profitability analysis - has become one of the most used (and mis-used) methods of economic analysis available. Companies assess project viability using it. Regulatory boards accept or reject investment applications with it. International aid agencies appraise projects with it. If peasant farmers paid attention to their extension workers, they would abandon their traditions and sow their crops based on it. The fates of hydro-electric projects, timber concessions, and resettlement schemes are influenced by it. Profitability has, it would seem, become synonymous with efficiency.

But there is more to efficiency assessment than costbenefit analysis and the reckoning of profitability. In this section, we look at some common measures of efficiency and inefficiency.

\section{Profitability Indices}

If we could design the ideal measure of profitability, one that exactly assesses the true robustness and economic prospects of projects, companies or economies, we would not be writing this paper. We would long ago have retired, basking in the riches gained from unimaginably successful investing.
But the quest for such a measure is incessant, and everybody seems to have their favorite indicator. In assessing corporate viability, we might refer to profit margin, debt-equity ratios, or cost to sales ratios. In considering economic robustness, we may be more interested in cost-minimization issues, or strategic issues related to market diversification. All of these give insights into how productive and profitable a given venture is. But in analyses of economic efficiency, most reports present either an 'internal rate of return' (IRR), a benefitcost ratio (BCR), or a project 'net present value' (NPV).

All of these economic indicators weigh the income and cost streams, over time, from a given activity. Of the three, the literature is clear that NPV is the only appropriate means for assessing project viability, although it took many years of debate before major organizations (e.g., the World Bank) finally dropped the others from their assessment criteria. Even so, use of NPV for project and viability analysis has come under some fire. Primarily it is because the methods to obtain such a measure are difficult to apply, and are thus often done improperly.

For a project analysis to be meaningful, it must implicitly or explicitly reflect what would happen in the absence of a given activity. It is relatively meaningless to conclude, for example, that a forestry project will generate a net income of $\$ 1$ million a year, if by doing something slightly different one could generate a net income of $\$ 10$ million a year. Proper analyses of NPV (and even of IRR and BCR) should reflect such a 'counterfactual' case; but identifying this case, and assessing its consequences, is one of the most difficult and mishandled parts of project evaluation and profitability analysis. Proceeding with the project that generates the $\$ 1$ million may appear profitable, but it is in fact grossly inefficient given the alternatives.

A second issue with such profitability analyses, and the indicators that arise from them, is that they typically focus only on income and cost streams. This is valid if 
we are mainly interested in efficiency, but many economic issues also deal with 'asset values'. Although it is common to find measures that show a return on invested capital, the capital so valued typically excludes the most significant asset of the entire operation: the standing forest itself. This aspect - which economists call 'natural capital' - is given little attention in most profitability measures.

\section{Rent}

In many countries, ownership of natural resources minerals, petroleum products, forests, fish - is vested in the State. The State, as owner, must see to the management of these resources. If it does a good job looking after them, then the resource generates 'rents'. These rents represent values above the cost of harvesting and looking after the resources. If it does a poor job, by destroying the asset, by mismanaging the asset, or by spending more than the required amount of money and effort, then these rents can diminish. Most of the effort in maximizing the rents lies in proper technical management of the resource and in using the lowest cost methods to do so. The extent to which a given property, region, or country generates economic rents is therefore a potentially powerful indicator of economic efficiency.

But measuring this rent can be complicated. It is typically divided among four key players: the owner, the manager, the consumer, and, occasionally, local forest dwellers. The actual level of rent realized, and the division of rent among these players, depends on a large array of institutional, policy, legal and technical circumstances. As we saw earlier, the royalty, fee or tax regime can have a significant effect on how much resource value is generated, and how much of it accrues to the State as owner. The manager, who may be responsible for any or all of logging, replanting, processing or marketing of the products, will typically enjoy a share of the rent. In some countries (e.g., Vietnam), the State itself is the manager in the form of a state-owned company, and captures rent via company profits. Domestic consumers may also share in the rents through consumption subsidies. Rent shares to consumers are typically low, except in instances where entire forest stands have been turned over to communities to manage. In India, for example, over 300 community cooperatives have been established to manage, harvest and use timber and products from state-owned lands. Finally, local forest dwellers - often having traditional use rights - may be compensated through direct payments.

Measures of rent can take different forms: dollars per ha; dollars per cubic meter sold; dollars per cubic meter logged; or, simply, \% of export value. All will provide an indication of economic efficiency: they all reflect, to some degree, both the economic efficiency of harvesting as well as the influences of the institutional and policy context. Another advantage is that, in monitoring rents, one also obtains some idea of distributional issues; one can readily assess the share of the rent collected by each of the major players. As with the profitability indices, these measures do not, however, necessarily say anything about the value or condition of the forest as an asset.

\section{Waste and Losses}

Both profitability and rent require that we pay attention to prices, costs, or other money values. The problem with such measures is that they can change quite quickly in response to external factors. Currency devaluations, changes in international prices, or sudden inflation may all apparently shift such measures. More significantly, inefficiencies may be masked by such 'external' factors so that it appears that operations remain efficient.

For this reason, many efficiency assessments concentrate entirely on parameters that are not affected by price fluctuations. The most common measures are, quite simply, physical measures of waste or loss. Residual stand damage, volume killed but not removed from the forest, or average stump height are all legitimate measures of waste or loss. In addition to assessing current 'efficiency', they provide some insights into the condition of the forest stand: the asset that will inevitably be responsible for generating any future income streams or economic value.

\section{Lessons}

Rational decision-making dictates that we pay attention to economic efficiency. Measuring such efficiency, however, is not always a simple task. Commonly used measures of profitability, such as IRR or BCR, can be misleading. Measures of rent seem to provide a clearer picture of overall efficiency, as they show the collective impacts of stand management efforts, industrial structure, institutional effectiveness, and economic policy neutrality. The flaw in many of these approaches, however, is that they fail to reflect asset damage: measures of 'economic wealth' effects in forestry management are often ignored in the entire reporting framework.

At a purely practical level, therefore, measures of 'physical inefficiencies' may in fact be the easiest to use. Increased waste typically leads to near-term economic losses, and such measures also reflect asset damage that is not otherwise captured by most income measures. In short, just as it is easier to detect 'unsustainable' forest use than it is to define and detect 'sustainable forest use', we propose that it is easier to measure and detect economic inefficiency, than it is to detect efficiency. 


\section{PART 5}

\section{Of Privilege and Poverty: Issues in Equity}

"WORK IS LIFE, You KNOW, and without it, there's nothing but fear and insecurity."

- John Lennon, British rock musician, 1969

"IF I WERE A Brazilian WITHOUt LAND or money or the means to feed my children, I would be burning the rainforest too."

- Sting [Gordon Matthew Sumner], British rock musician, 1989

A RTISTS, MUSICIANS, AND COMMUNITY elders probably have a keener sense of what is fundamentally 'right' or 'wrong' about a given forest management system, than do your average economists, politicians, or planners. To obtain a 'first-best' indicator, it may make most sense simply to spend a few hours with the local scribe, bard, or juju chief, asking them if they think current practices are fair. If one cannot locate such a person, however, then one will need to turn elsewhere for insights into equity issues such as employment, taxation, and income distribution, all of which are extensively addressed in the annals of economic inquiry. ${ }^{2}$

\section{Employment}

'Job' indicators play an integral part in the rhetoric of politicians, environmentalists, and industry spokespersons alike. Employment generation is often regarded as one of the most critical dimensions and indicators of economic equity: it provides a key measure of local participation in forest management, and points to local income generation. Some argue that, if one employs more local labor, then it is more likely that forest management will be sustainable as local dwellers have a long-term interest in the land-base. But obtaining and interpreting employment information is not without difficulty.

For temperate forests, we can readily find the job creation potential of almost any type of management system in any type of forest area. In Western Canada, for example, interior 'conventional logging' can generate 0.1 jobs per cubic meter of timber of production, while 'labor intensive ecoforestry' would generate 0.5 jobs per cubic meter. Ecoforestry may seem like a good deal, job-wise, until one realises that the production from ecoforestry would only be about $4.4 \%$ of conventional timber production over a four year period. Even though the ecoforestry cut can be sustained indefinitely while conventional methods would eventually create conditions where even fewer jobs would be generated, total job creation within the four year period is less for ecoforestry than it is for conventional methods.

The four year analysis period in this example may seem arbitrary but it is not: it is the average period of tenure for local politicians. Given this, it is perhaps not surprising that very little ecoforestry is promoted, and that current policies discourage it.

Obtaining such comparative employment indicators for developing countries is, however, no simple task. Interpreting such employment indicators is, however, problematic. And even if one can obtain such information, the above example illustrates that the same numbers can be interpreted in two different ways. On the one hand, employment measures stated in efficiency terms (jobs per unit) may appear to favor one method, while a slightly different use of the same information (deriving total jobs) may appear to favor a different policy direction.

Finally, as with many employment indicators, simple employment numbers paint only a partial picture. People now speak, for example, of 'good jobs' and 'bad jobs': good jobs are those that provide sustainable income and a workers' voice in management decisions, while building the character of the worker. Bad jobs may provide income, but they degrade the worker. Some will argue, for example, that the proliferation of fast-food outlets we see in industrialized and developing nations generate mainly 'bad jobs.'

\footnotetext{
${ }^{2}$ Employment and ecoforestry figures in this section are based on analyses conducted by Hammond et al. (1994), Drengson and Taylor (1997) and Green (1998). Further reading on income distribution issues can be found in Tognetti et al. (1995), who provide a comprehensive review of poverty and environmental linkages within an economic framework. Examples of material dealing with indicators on distributional issues can be found in Sen (1992, 1993) and Ruitenbeek (1996); a review of the literature relating to the policy uses of income distribution indicators is given by Blackwood and Leach (1994).
} 
So which is more equitable? A high paying job in an unsustainably managed industry? Or a low paying job in a sustainably managed forest? No clear answer can be given to this query. Perhaps all one can say is that both of these situations are preferable to no jobs at all, which is why many criteria simply look to improve local employment opportunities and local participation rates.

\section{Taxation}

Benjamin Franklin once remarked that, "nothing is certain, except death and taxes." Neither of these two realities seem very equitable. But the issue of taxation, in fact, has two important equity dimensions to it that are relevant to forest stand management: rent distribution; and, progressivity.

As described earlier, rent is a measure of the net value of the harvested resource, in pure efficiency terms. An absence of economic rent certainly indicates inefficient and unsustainable management. How positive economic rent is distributed, however, is both an efficiency and an equity matter. If inadequate incentives - through participation in rents - are given to operators and managers, then conditions in the forest stand are inevitably neglected. On the other hand, if the owner (e.g., the State) extracts inadequate rent, then key monitoring, research, or regulatory institutions may be underfunded and ineffective. Taxation is therefore a key means to capture some level of rent that is both efficient and equitable; such taxes, after all, belong to society as a whole.

Progressivity is somewhat more nuanced. Robin Hood - who took from the rich and gave to the poor was likely one of the first progressive tax authorities around, although the legal (if not the moral) basis for his interventions may be in dispute. Incidence of taxes in forestry is similar: there is some evidence that shows that taxation and fee systems in many developing countries often favor larger, wealthier, vertically integrated, corporations and discriminate against smaller operators. Identifying and correcting such situations would, for a rational taxation authority concerned with equity, be of key concern.

\section{Income Distribution}

Poverty has many faces. We can see it in the faces of the ill and the illiterate. We can see it in the faces of women or ethnic minorities living lives of oppression. We can see it in the faces of children, forced into labor or prostitution. We can see it in the humility people experience when there are no sanitation facilities available. And we can see it in their weariness from walking for hours, every day, to gather cooking fuelwood.

Economic inquiry has, with other disciplines, spent considerable effort analyzing some of the linkages between poverty, environmental degradation (including deforestation), and economic conditions. Typically, the economic approach to the problem focuses on income or assets held by otherwise disadvantaged groups. Within the indicator field, formal measures have been derived, relating generally to what one might call 'distributional' measures and 'incidence' measures.

Traditional economic models of inequality have focused on measures of income distribution. One such commonly understood measure is the Gini Index, which falls within a range of zero (for perfect equality) to unity (for perfect inequality). Similar indices, such as the 'Pa', 'Sen', or 'Atkinson' Indices, all attempt to capture some form of income inequality. All of these inequality measures have a common weakness, however: they typically measure only the marketable income or, in rare circumstances, impute some value to non-market transactions of bartered goods. They also must be applied to relatively large samples of the population.

In many cases, simple 'incidence' measures will be adequate to demonstrate whether particular groups are adversely affected. Participation (or, more usually, lack thereof) is a common impact measure when it comes to looking at reliance of local people on forest resources. Reviews in the NTFP literature, for example, often illustrate that large proportions of those living in, or close to, forests, rely to some degree on NTFPs for subsistence or cash income.

\section{Lessons}

Justice and fairness are generally regarded as desirable and noble traits. Defining and measuring these traits, however, has been a past-time of philosophers for millennia, and debate is far from settled: we have only to look at the dynamic nature of modern legal systems to realize this. The 'ideal' democratic system, or 'ideal' system of justice, or 'ideal' understanding of fairness, has yet to be entrenched in any modern society. Yet most people are quite capable, in their own minds, of calling a given system 'undemocratic', 'unjust', or 'unfair.'

In terms of looking for measures of equity, this suggests a similar stance. Most of our measures try to identify situations where someone - government, workers, the poor - is being treated inequitably. From a theoretical view, rationality means that we promote equity. From a practical view, however, rationality means that we seek out and destroy inequity. 


\section{Of Plans and Paradise: Issues in Sustainability}

"IN PREPARING FOR BATTLE I have always found that plans are useless, but planning is indispensable."

- Dwight D. Eisenhower, US general, Republican politician, president, 1962

"FLOWERS ... ARE A PROUd ASSERTION that a ray of beauty outvalues all the utilities of the world."

- Ralph Waldo Emerson, US essayist, poet, philosopher, 1844

$\mathrm{I}^{\mathrm{n}}$ N 1972, BARBARA WARD OF THE IIED first used the phrase "Sustainable Development" and it seems to have stuck. Part of its appeal is no doubt that it is open to such broad interpretation. David Pearce counted almost 300 definitions in 1989, many of them mutually exclusive. Since then, most analysts have stopped counting, and it is certainly not our intent to review the definitions or to select a preferred one. Suffice it to say that economists have probably contributed more than their fair share of definitions.

Within all of these definitions, however, a number of themes emerge that do seem consistently to play a part in achieving sustainability. Sustainability generally teaches us to pay more attention to the needs of future generations, and to the longer-term social and environmental ramifications of current production and consumption decisions. These themes apply as much to individual stands as they do to entire national forest estates. Within this context, the major economic topics we deal with here are environmental externalities and natural capital. ${ }^{3}$

\section{Planning}

We note that both of these economic issues are, in different ways, linked to the concept of promoting intergenerational equity. While the previous chapter considered distribution of income and entitlements within an immediate timeframe, economic sustainability focuses on future generations. Within this construct, the actual methods and roles of economic planning have been slowly changing, as well. Traditionally, planning has resulted in a plan, which one then follows and monitors progress against. This is also a common model for many forest management planning exercises. But economic sustainability demands something more.

The "future" is a moving target. The main idea of economic planning in an intergenerational sense is that we must think continuously about what might happen to this target. Through engaging in a planning process, we consider the consequences of our actions, we think of objectives we might have, and we think of what might go wrong or right as we follow a given path. The end point of this process - The Plan - may be of less consequence than the process that generated it. This describes a scenario of 'adaptive planning', which involves a continuous and active planning process before and during project execution.

In tropical moist forest, for example, management considerations may have to change with time. Certainly in the first felling cycle, concerns will likely be dominated by timber production, in spite of the fact that there are many other NTFPs. Some observers note, however, that it is possible that NTFPs may become increasingly important during the second and subsequent felling cycles; management planning will need to accommodate such possibilities and adapt accordingly when and if this does occur.

Incorporating such adaptive management requires substantial institutional reforms. Many forestry institutions are still geared to 'sustainable yield' management. With sustained yield, the planning focus is on a narrow physical aspect of forest management, rather than on economic sustainability criteria. Reforestation and silviculture for maintenance of annual allowable cuts (AAC) implies the sustained yield paradigm, rather than enhancement of the forest estate for future generations. While institutions traditionally looked at the 'constraint' of sustained yield, and then monitored progress

\footnotetext{
${ }^{3}$ An example of the adaptive management planning models discussed in this section is provided by Faucheux and Froger (1995), who advocate a decision-making process of 'procedural rationality' as an appropriate means to address many long-range environmental problems that involve uncertainty or irreversibility. The valuation figures in this section are based on ecological economic studies conducted by Costanza et al. (1997), which appeared in Nature, and on unpublished background working documents made available to interested parties. The methods used are termed 'Benefit Transfer' approaches, as they assume that valuation methods conducted in detail in one part of the world can be translated with some adjustments to similar ecosystems elsewhere.
} 
accordingly, an adaptive planning process would address - on a continuous basis - the 'goal' of sustainability.

\section{Externalities and Valuation}

Entire volumes have been written about the economic valuation of environmental externalities. Methods are well-developed, and when reading the environmental pages in the local papers, we are now more regularly treated to a diet of dollars where in the past we would read only of disaster.

But what does it mean when accounts, such as those appearing in Nature in mid-1997, tell us that world ecosystems have a value of about three times the world's GNP? Or that the ecological services from tropical forests are about seven times as large as the services from temperate forests? Or that the genetic biodiversity resources in tropical forests have an annual value of US\$41 million, while the annual value of climate regulation of these same forests is US\$223 million? In all of these cases, analysts have placed a 'price' on a good or service that currently has no market. That price may, for example, represent what it would cost to replace the service through man-made means, or it may represent the damage that would be inflicted if we were to lose that service. This, in a nutshell, is 'valuing externalities.'

Valuation methods have their opponents and proponents. Opponents may cite the cost and complexity of undertaking such studies properly, the wide range of methodologies available for undertaking analyses, or simply that some things on this planet are sacred and should not endure this type of treatment. Proponents typically argue that such analyses are useful in helping people rank or set priorities, in improving our understanding of how the economic and ecological systems are linked or, more practically, in getting the attention of policy-makers.

In applying such methods to the FMU, a few practical considerations should be kept in mind. First, the methods can indeed be quite expensive and might not be costeffective for goods and services other than readily identified material flows (such as NTFPs). Use of such methods for more complex ecosystem functions is a misapplication of the technique at the FMU level. Second, physical indicators are often available that provide adequate substitutes for measuring economically important functions.

\section{Natural Capital}

The idea of 'GNP' is now so common that most people take it for granted as an economic production indicator. But few realize that the measure underwent decades of testing by different countries before it became the indicator that it is today. Its calculation, entrenched by the United Nations Statistics Office (UNSO), is now part of what we refer to as the System of National Accounts (SNA).

A similar process is now underway in a field known as Natural Resource and Environmental Accounting (NREA). For some time, analysts have realized a number of shortcomings to the GNP measure. Notably, it measures only income flows, without capturing the impacts that such income flows would have on capital stocks. A country that clearcuts and sells all of its forests over a five year period would, using the GNP measure, show more rapid growth than if it were to cut that same resource over a longer time horizon. Also, costs incurred to restore environmental damage are regarded as positive income flows in a GNP calculation.

But intuition tells us that such actions, within a 'sustainable' economy, should not necessarily be counted as 'growth.' Therefore, after considerable consultation and theoretical development, the UNSO issued, in 1990, draft guidelines for implementing NREA methods. Experimental methods are being used in many industrialized and developing countries to assist in strategic planning and priority-setting. Because no single methodology could be identified that was superior to any other, the experimental accounts permit countries to pursue this task along any lines that they wish. In its NREA efforts, for example, Indonesia focused on oil and gas, and forestry. The forestry accounts stressed damage estimates, and adjustments for capital depletion. The experimentation phase for this process will continue well into the next century, at which time some harmonization of methods may occur.

Although the actual accounting task is of interest, the main point of this activity is that it represents a shift in economic paradigm. It reflects the idea that "natural capital' is indeed important, and that we should somehow account for it. We can no longer simply 'eat' our limited stocks of capital, without thinking of the implications on future generations.

Within the framework of natural capital, apart from the accounting exercise noted above, economists have also engaged in debate and research as to the substitutability of such natural capital with other capital. "Do forests have substitutes?," one might ask. There is, perhaps not surprisingly, as yet no resolution of this issue.

\section{Lessons}

Sustainability is quite elusive. The obverse unsustainability - once again seems to be easier to detect, and current efforts are likely to focus on stamping out unsustainable activity. To accomplish this specifically, in C\&I design, we pay closer attention to the stock and quality of remaining forest and to the flow of non-timber goods and services from the forest. 


\title{
Good Forests, Good Policies, Good Institutions \& Good Luck: A Recipe for Sustainability
}

\author{
"WE ABUSE LAND BECAUSE we regard it as a commodity belonging to us. When we see land as a community to which we belong, \\ we may begin to use it with love and respect." \\ - Aldo Leopold, US forester, ca. 1945 \\ "IN SHORT, Luck's always to blame."
}

- Jean de La Fontaine, French poet, fabulist, 1678

$\mathrm{W}$ HEN YOU BAKE A CAKE, leaving out even one key ingredient will bring failure. Sustainability seems to be a similar enterprise. We have seen that good stand management, good economic policies, and good institutions are all key ingredients in sustainable management. What we often fail to appreciate, however, is that we also need a certain measure of good luck.

Scientists have a term for incidents that others might construe as good luck or bad luck: they call these 'stochastic exogenous non-linear events.' These events are random, are out of our control, and are inherently unpredictable. Under the rubric of 'uncertainty', economists and others have started paying closer attention to such events. A major lesson is that, as systems become larger and more complex, random events seem to escalate. Economies, especially those undergoing rapid change such as those in developing countries, seem to get more than their fair share of such shocks. Anticipating and planning for these eventualities has therefore started to attract the attention of policy-makers.

One can point to numerous instances where system complexity leads to surprises. A mixture of droughts, poor policies, and El Niño conspired to create the unprecedented forest fires experienced in Indonesia in 1997 and 1998. Any of these events by themselves may not have lead to such calamity, but together they created an environmental shock that exceeded the response capacity of local institutions and management agencies. One attribute of all of these shocks is that the system affected itself tends to reinforce them. We may be able to do very little about the onslaught of a hurricane or earthquake or volcanic eruption, but, if the system itself responds in a negative manner that reinforces the original shock, then matters escalate and worsen. We call this negative feedback. Social scientists also call this selffulfilling prophecy: if everyone believe that things will get worse, then they start to take actions to protect themselves individually; collectively this places unbearable pressures on fragile systems and, indeed, things do get worse.

There are numerous 'systemic' attributes that are likely to cause such negative feedback. Most, in our view, seem to have something to do with complex politicaleconomic interactions or socio-economic reactions. Two such attributes that we consider here are insecure land tenure and political corruption. Both are economic issues, though with strong political and social overtones. Or, some might argue, they are fundamentally political and social issues with strong economic overtones. In either case, their existence seems to magnify the effects of any other shock or action that occurs to the system, whether that shock relates to bad weather, onset of war in a neighboring country, or the sudden outbreak of disease.

\section{Risk and Uncertainty}

Before considering these systemic issues, it is important to distinguish between risk and uncertainty. Generally, from an economic perspective, risk is something quantifiable while uncertainty is not. We are capable of attaching probabilities in situations of risk, while under situations of uncertainty we can not assign such probabilities because of lack of experience or simply because the cause-effect relationships are too complex to predict outcomes. Different approaches and methods have been used to address these inherently different situations.

The approaches can involve: sensitivity analyses, risk analyses based on probability distributions, risk analyses based on adjustments to the discount rate, or explicit calculations of option values. Sensitivity analyses are not generally very instructive in practice, and 
probability-based analyses do not address the problems of unquantifiable uncertainty. Also, discount rate approaches have largely been discredited as an appropriate form of risk analysis for environmental problems. In principle, discount rates are used to give greater or lesser weight to future preferences. But there is no a priori reason for assuming that either an increase or a decrease in discount rates will be more representative of an environmentally sensitive appraisal; lower discount rates may tend to place more weight on future generations' preferences, but use of such lower discount rates also causes more investment to occur in the current period. Such increases in investment could themselves have deleterious environmental impacts. In short, most informed analysts no longer use such approaches to address risk or uncertainty.

'Option value' methods remain as a potentially applicable technique for addressing uncertainty. Essentially, these approaches place a value on 'undisclosed future information'. Actually calculating these values empirically is very complex, and usually not very helpful in and of itself. But the theoretical literature in this field confirms the intuition: where uncertainty exists, it makes sense to keep our options open.

\section{Tenure}

In the next chapter we see that 'tenure' issues seem to insinuate themselves into all aspects of forest management: from stand, to institution, to policy. Governments have risen and been defeated over tenure issues. Fortunes have been won and lost. Forests have been denuded and saved. Security of tenure is cited, perhaps more than any other factor, as a prerequisite for sound forest management by concessionaires.

But tenure security seems to be an elusive concept. There is nothing 'absolute' about it. Well-defined private property rights do not guarantee sustainable stand management, unless they are backed up by secure monitoring and enforcement institutions. Loosely defined communal property rights often seem to enhance sustainable management, largely through social traditions. But apart from such relatively vague generalizations, few unambiguous statements can be made about the equity, efficiency or sustainability impacts of different tenure regimes. All we can say is that 'insecure tenure' often leads to unsustainability.

One part of the tenure security issue relates to the propensity of governments to maintain centralized control over land. Central governments typically overestimate their own ability to manage the forest estate and under-estimate the abilities of those traditionally dependent on the resource. Traditional users are familiar with the broad range of forest functions and sustainably harvestable products. When governments have usurped traditional use rights, forest and forest boundary communities are no longer compelled to protect the resource from over-exploitation or destructive encroachment, and governments are not equipped to do so. Negative feedback results: control becomes further centralized as local populations apparently mismanage the forest; lack of respect for central authorities, coupled with lack of monitoring, results in further encroachment. Eventually, the system breaks down.

Scale seem to further exacerbate effects, as is characteristic of complex systems. In many areas where the government forest estate is very large, rural people simply do not recognize the central government's ownership of the forest because there is no obvious government presence. Once an area of forest has been logged by concessionaires, rural peoples often assume that the government is no longer interested in the land that they still consider to be communal property. As a result, itinerant farmers illegally finish the clearing; economic policies implicitly permit this activity. This entire scenario could be reversed if some of the negative feedbacks were dampened: practically this may mean adjusting economic policies, providing stronger institutional support, or strengthening and recognizing traditional tenure over the forest stand.

\section{Corruption}

'Corruption' is a word one does not use lightly. It takes on many forms, and one often finds disagreement about what does and does not constitute corruption. Most dictionary definitions of corruption make reference to 'bribery.' And a common definition of a bribe is, "A price, reward, gift, favor or something of value bestowed or promised with a view to pervert or corrupt conduct." At this level, corruption has a distinct 'economic' flavor to it. But corruption is a complex topic extending beyond economics. $^{4}$

Some would argue that corruption is defined differently in different cultures, and that certain types of corruption are tolerable, or even desirable. Others see corruption as an 'absolute sin.' A recent OECD convention, signed in December 1997, prohibits certain 'corrupt' activities in dealings with developing countries.

\footnotetext{
${ }^{4}$ Additional information on general effects of corruption is available through Transparency International at http:// www.transparency.de/. Earlier case studies dealing with forestry impacts within the context of economic analyses can be found in Mergen and Vincent (1987), Grut et al. (1990), Winterbottom (1990), Gillis (1992), Schleifer and Vishney (1993), and Manzetti (1994).
} 
In some cases, these corrupt dealings involve payment of relatively small discretionary 'fees' to expedite service; this is a common practice in many countries where civil service salaries are low and where such payments are tolerated locally. In other cases, these corrupt dealings involve substantial payments to the wealthy or to the politically well-connected. The forestry sector is no stranger to such corruption, and many accounts - both formal and informal - document the negative effects it can have on forest sector sustainability. It is, in our view, a systemic feature that contributes to unsustainability through negative feedback.

Administrative discretion has been the most common method of awarding concession rights to eligible forest operators. In the absence of clear and published decisionmaking guidelines, concession allocation by administrative discretion leaves ample opportunity for financial irregularities and collusion. Concession eligibility is usually clear and varies with country policies regarding participation by nationals. However, government criteria for awarding concessions is usually unavailable so the basis for allocation decisions is unknown. There is evidence of favoritism given to particular political groups, and sometimes to military interests.

Similarly, the criteria for renewal in concession agreements are rarely clear and as a result also tend to administrative discretion. Renewal which is based on "favorable performance" - instead of on stipulated criteria - contributes to tenure insecurity. In the absence of any certainty about renewal, concessionaires often "cut and run" because concessions become political prizes that can be expropriated without compensation, at the whim of the political leadership. As concessionaires become less entrenched, it provides even more opportunity for corrupting influences to gain from the residual lands.

But these events have clear impacts on sustainability. Concessionaires that cut and run inflict considerable damage on the residual stand. As they have no long term interest in the concession, they do not incur the cost of extraction damage. Also, they are unlikely to adhere to logging regulations regarding stand re-entry. Fearing the arbitrary revocation of their licenses, concessionaires will re-enter cut-over stands. Evidence shows that premature stand re-entry inflicts substantial damage to the growing stock and the residual stand is twice damaged. Also, if concessionaires do not want to be held to their reforestation obligations, they have been known to ignore and even encourage the activities of shifting cultivators.

\section{Summary}

The rationality of sustainable management has to do with more than just what we know. It also extends to managing for what we do not know. Many systems we deal with are complex, and often seem influenced by arbitrary events. As systems become more complex and larger, our ignorance of what might happen escalates as well. Acknowledging this ignorance is the first step in addressing it. The second step is acting on it: acting in a way that the systems we steward - whether entire economies or single forest stands - are resilient to the shocks that our ignorance prevented us from foreseeing.

At a practical level, this means that we should make increasing use of flexible, precautionary policies and projects. This simple precept - the 'Precautionary Principle' - is all we need to know to address uncertainty, decrease our bad luck, and increase our good luck. 


\title{
PART 8
}

\section{Measure for Measure: A Review}

\author{
"What difference does it make how much you have? What you do not have amounts to much more." \\ - Seneca, Roman writer, philosopher, statesman, ca. 65 AD \\ "Counting is the Religion of this generation: it is its hope and its salvation." \\ - Gertrude Stein, US author, 1937
}

$\mathrm{T}$ HE EFFORT EXPENDED to date in developing criteria and indicators for sustainable resource management has been phenomenal. Testimony to this are the large 'laundry lists' of indicators one finds in documents on the topic. This applies to many areas of sustainable development planning: forests, fisheries, community involvement, democratic freedoms, global climate change, and so on. By contrast, very little effort has been expended internationally trying to decide whether these indicators are, indeed, helpful in decision-making and resource assessment. Remarkably little evaluative work has been done of proposed indicator sets.

The evaluative work that has been done, however, has some poignant lessons to teach us. Many of these lessons boil down to a simple fact that, to be practical, we should be less ambitious in the complexity that we build into individual C\&I, and into the set overall. In this section, we review these lessons, looking eventually at some of the C\&I that CIFOR had previously developed.

\section{Lessons from Elsewhere}

We can commence our comments with reference to the handful of evaluative studies that have been done relating to economic C\&I in sustainable development. Most of this evaluative work comes about after specific empirical studies were conducted to look at the effectiveness of indicators in resource planning. ${ }^{5}$

- A single economic indicator should not be used as a diagnostic tool. This may be the single most fatal assumption we make in the use of economic indicators. A single indicator does not capture system complexity, and lacks the ability to track dynamic changes in the system. Buzz Holling, a respected ecologist, once remarked that, "In my field, you would be laughed out of court if you tried to describe a non-linear system with less than three variables. One measure, by itself, won't describe a non-linear system." Economists, and those using economic indicators, should take similar heed.

- Information constraints severely limit development of indicators. Environment Canada's Indicator Division recently embarked on a 2 -year experiment to look at the availability of information for ecosystem-based economic evaluation. The study commenced with almost 1000 potential indicator series, and eventually audited 130 indicator series that had actually been measured within sub-units of a 23 million ha river basin consisting primarily of forest lands. The indicators were evaluated on the basis of their usefulness in common economic analysis models (econometric, input-output, and complex system models). Of those modeled, $83 \%$ were found to have fundamental statistical flaws (e.g., not independently estimated even though they may have been represented as such) that made them useless in an applied sense. In a practical sense, the work recommended that efforts concentrate on 11 economic indicators that could reasonably well represent all of the aspects of the system. Evaluative work relating to nutrient loading in the Baltic Sea region recently came to similar conclusions: most available measures are unreliable for use in decision-making.

- Good time-series data are critical for economic planning. To the credit of analysts, planners, and decision-makers, creative thinking has often resulted in the design of new and innovative approaches to indicator design. Clever combinations of social, ecological and economic parameters have - in some instances generated composite indicators that would appear to capture a host of sustainability issues. While these

\footnotetext{
${ }^{5}$ In addition to the general literature cited in the References, this section relies specifically on a comprehensive review by Tognetti (1997), on case studies for Canada by Lonergan, Ruitenbeek, and Gustavson (1996), on case studies for Norway by Vatn et al. (1998), and on work on composite indices by Daly and Cobb (1994), Holling in Potvin (1992), and Sen (1993).
} 
indicators have theoretical merit, there is seldom a historical record that permits us to look at their progress over time. Such time series are critical in economic planning. Such new indicators may, therefore, be of some use in 20 years (and monitoring should perhaps commence now in those countries where sustainability issues are not yet that pressing), but they have little value in near-term decision-making. In the case of forestry, they would have absolutely no value in the assessment of certification guidelines.

- Single indices make good communication devices. Much work has been done on deriving composite economic sustainability indices, ranging from 'Green GNPs' to the UN 'Human Development Index'. While such indices may have little value as planning or diagnostic indicators, they have proved to be valuable communication devices to draw attention to other problems such as poverty, malnutrition, or illiteracy.

- Consider human health. The only area in which a composite index seems to have some diagnostic ability relates to indicators of human health: Amartya Sen, a respected economist who has for decades been observing patterns of economic development and has contributed extensively to the literature of valuation, economic development, and poverty alleviation, argues that 'human health indicators' in many instances provide a composite snapshot of economic, social, and environmental factors. An advantage to such indicators is that there are long historical records and good measurement protocols available. Considerable work is therefore now focusing on the use of such indicators as diagnostic tools.

\section{Seven Sets}

Seven sets of C\&I were examined to determine what their developers consider to be of an 'economic' importance, and what economists might consider to be of importance. Representative economic indicators were then described by: (i) their ability to say something about the goals of economic efficiency, equity, and sustainability; (ii) their relevance to different points of intervention (stand management, institutional, and policy levels); and (iii) their administrative applicability (national, regional, local) according to the developer. ${ }^{6}$ For example, "Number of direct and indirect jobs and level of income." tells us something about equity, at the stand, and it is to be gathered at the local (FMU) level.

The indicators so collected reveal a number of features. First, indicators of stand productivity preservation (yield, AAC, extraction damage, silviculture) are not considered 'economic' indicators in spite of their economic efficiency implications.
Second, common 'economic' indicators pertain to production volumes, values and diversity; investment levels and rate of return; and employment opportunities. Third, indicators of efficiency and equity usually point to stand management intervention. Fourth, indicators of economic sustainability usually point to both stand and institutional level intervention. Finally, there are few indicators providing economic information which would point to policy intervention (stumpage rates, market prices).

\section{The CIFOR Set}

Table 4 contains the CIFOR C\&I developed from the 1996 field test of some $500 \mathrm{C} \& \mathrm{I}$. For this paper, the CIFOR set was evaluated in the same way that the above seven C\&I sets were evaluated. For example, "Skidding damage to trees and soil minimized" says something about economic efficiency and points to intervention at the stand management level.

If 'economic' indicators are only of the type commonly called such, as in the above seven sets, then the CIFOR set is nearly void of economic indicators, save for those pertaining to economic equity employment benefits and opportunities, and participation in management. ${ }^{7}$ However, not all indicators of economic importance are labeled as such. Economic efficiency is concerned with the maintenance of the productive capacity of the stand; the CIFOR set contains many indicators regarding its condition and treatment. ("Harvesting systems ... reduce impact."). As with the other sets, CIFOR's indicators of efficiency and equity point primarily to stand management intervention.

CIFOR indicators capturing aspects of economic sustainability usually point to intervention at the local level, which is not surprising given that the set was field tested specifically for application at the FMU. Nonetheless, some potential FMU conditions revealed by the indicators would be most effectively addressed at both the stand and institutional levels.

As in the other sets, indicators pointing to policy intervention are few. The "Policy, Planning and Institutional Framework" principle is concerned with land use planning policies. These are important

\footnotetext{
${ }^{6}$ Annex B contains examples from the C\&I sets of the International Timber Trade Organization; the African Timber Organization; the Amazon Cooperation Treaty countries; Initiative Tropenwald, Germany; The Soil Association, UK; Rainforest Alliance, US; and Lembaga Ekolabel Indonesia.

${ }^{7}$ In addition to the C\&I that resulted from the 1995 field test, CIFOR proposed additional indicators in a more recent report (CIFOR 1997). These additional indicators pertain primarily to biodiversity and economic equity.
} 
indicators with far-reaching implications for economic sustainability; sector specific policies are also very important.

\section{Summary}

If we take away only one lesson from all of this C\&I work it should be this: be brief and keep it simple.

Table 4. Assessment of CIFOR Criteria \& Indicators

\begin{tabular}{|c|c|c|c|c|c|c|}
\hline \multirow[b]{2}{*}{ Principle, Criterion, Indicator } & \multicolumn{3}{|c|}{ Goal } & \multicolumn{3}{|c|}{$\begin{array}{l}\text { Intervention } \\
\text { Point }\end{array}$} \\
\hline & $\frac{\partial}{0}$ & 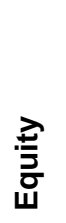 & 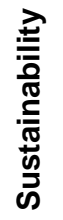 & 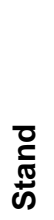 & 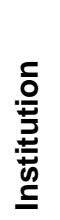 & $\frac{\mathrm{d}}{\overline{0}}$ \\
\hline \multicolumn{7}{|l|}{$\begin{array}{l}\text { Policy, Planning and Institutional Framework are Conducive to Sustainable } \\
\text { Forest Management }\end{array}$} \\
\hline There is sustained and adequate funding for the management of forests. & $\star$ & $\star$ & $\star$ & & $\star$ & \\
\hline Policy and planning are based on recent and accurate information. & & & $\star$ & & $\star$ & \\
\hline $\begin{array}{l}\text { Effective instruments for inter-sectoral co-ordination on land use and land } \\
\text { management exist. }\end{array}$ & $\star$ & & $\star$ & & $\star$ & \\
\hline $\begin{array}{l}\text { There is a permanent forest estate (PFE) adequately protected by law, which is } \\
\text { the basis for sustainable management, including both protection and production } \\
\text { forest. }\end{array}$ & $\star$ & & $\star$ & & $\star$ & $\star$ \\
\hline $\begin{array}{l}\text { There is a regional land use plan or PFE which reflects the different forested land } \\
\text { uses, including attention to such matters as population, agricultural uses, } \\
\text { conservation, environmental, economic and cultural values. }\end{array}$ & $\star$ & $\star$ & $\star$ & & $\star$ & $\star$ \\
\hline \multicolumn{7}{|l|}{ Yield and Quality of Forest Goods and Services Sustainable } \\
\hline $\begin{array}{l}\text { Management obiectives clearly and precisely described, documented, and } \\
\text { realistic. }\end{array}$ & $\star$ & $\star$ & $\star$ & $\star$ & $\star$ & \\
\hline $\begin{array}{l}\text { Objectives are clearly stated in terms of the major functions of the forest, with } \\
\text { due respect to their spatial distribution. }\end{array}$ & $\star$ & & & $\star$ & & \\
\hline A comprehensive forest management plan is available. & $\star$ & $\star$ & $\star$ & $\star$ & $\star$ & \\
\hline Maps of resources, management, ownership and inventories available. & $\star$ & & & $\star$ & & \\
\hline $\begin{array}{l}\text { Silvicultural systems prescribed and appropriate to forest type and produce } \\
\text { grown. }\end{array}$ & $\star$ & & & $\star$ & $\star$ & \\
\hline Yield regulation by area and/or volume prescribed. & $\star$ & & & $\star$ & $\star$ & \\
\hline $\begin{array}{l}\text { Harvesting systems and equipment are prescribed to match forest conditions in } \\
\text { order to reduce impact. }\end{array}$ & $\star$ & & & $\star$ & $\star$ & \\
\hline The management plan is effectively implemented. & $\star$ & & & $\star$ & & \\
\hline Pre-harvest inventory satisfactorily completed. & $\star$ & & & $\star$ & & \\
\hline Infrastructure is laid out prior to harvesting and in accordance with prescription. & $\star$ & & & $\star$ & & \\
\hline Reduced impact felling specified and implemented. & $\star$ & & & $\star$ & & \\
\hline Skidding damage to trees and soil minimized. & $\star$ & & & $\star$ & & \\
\hline $\begin{array}{l}\text { An effective monitoring and control system audits management's } \\
\text { conformity with planning. }\end{array}$ & $\star$ & & $\star$ & $\star$ & $\star$ & \\
\hline Continuous forest inventory (CFI) plots established and measured regularly. & $\star$ & & & $\star$ & $\star$ & \\
\hline $\begin{array}{l}\text { Documentation and records of all forest management activities are kept in a form } \\
\text { that makes it possible for monitoring to occur. }\end{array}$ & $\star$ & & $\star$ & $\star$ & & \\
\hline $\begin{array}{l}\text { Worked coupes are protected (e.g., from fire, encroachment and pre-mature re- } \\
\text { entry). }\end{array}$ & $\star$ & & $\star$ & $\star$ & $\star$ & \\
\hline Tree marking of seed stock and potential crop trees. & $\star$ & & & $\star$ & & \\
\hline
\end{tabular}


Table 4. (con'd) Assessment of CIFOR Criteria \& Indicators

\begin{tabular}{|c|c|c|c|c|c|c|}
\hline \multirow[b]{2}{*}{ Principle, Criterion, Indicator } & \multicolumn{3}{|c|}{ Goal } & \multicolumn{3}{|c|}{$\begin{array}{l}\text { Intervention } \\
\text { Point }\end{array}$} \\
\hline & 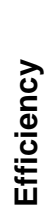 & $\frac{z}{\frac{7}{5}}$ & 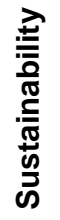 & $\frac{\text { C }}{\frac{\pi}{\pi}}$ & 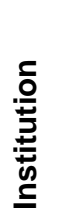 & $\frac{\text { do }}{\overline{0}}$ \\
\hline \multicolumn{7}{|l|}{ Maintenance of Ecosystem Integrity } \\
\hline $\begin{array}{l}\text { Processes which support and maintain biodiversitv of the forest ecosvstem } \\
\text { are protected or enhanced. }\end{array}$ & $\star$ & & $\star$ & $\star$ & $\star$ & \\
\hline Endangered plant and animal species are protected. & & & $\star$ & $\star$ & $\star$ & \\
\hline Interventions are highly specific, selective and are confined to the barest minimum. & $\star$ & & & $\star$ & & \\
\hline Canopy opening is minimized. & $\star$ & & & $\star$ & & \\
\hline $\begin{array}{l}\text { Enrichment planting, if carried out, should be based on indigenous, locally adapted } \\
\text { species. }\end{array}$ & $\star$ & & & $\star$ & & \\
\hline The capacity of the forest to regenerate naturally is ensured. & $\star$ & & $\star$ & $\star$ & $\star$ & \\
\hline $\begin{array}{l}\text { Representative areas, especially sites of ecological importance, are protected or } \\
\text { appropriately managed. }\end{array}$ & & & $\star$ & $\star$ & $\star$ & \\
\hline Corridors of unlogged forests are retained. & & & $\star$ & $\star$ & & \\
\hline No chemical contamination to food chains and ecosystem. & $\star$ & & $\star$ & $\star$ & & \\
\hline $\begin{array}{l}\text { Ecologically sensitive areas, especially buffer zones along water courses are } \\
\text { protected. }\end{array}$ & $\star$ & & $\star$ & $\star$ & $\star$ & \\
\hline No inadvertent ponding or waterlogging as a result of forest management. & $\star$ & & & $\star$ & & \\
\hline Soil erosion is minimized. & $\star$ & & & $\star$ & & \\
\hline \multicolumn{7}{|l|}{$\begin{array}{l}\text { (implied) Forest Management Maintains Fair Intergenerational Access to } \\
\text { Resources and Economic Benefits }\end{array}$} \\
\hline Stakeholders'/forest actors' tenure and use rights are secure. & & $\star$ & $\star$ & $\star$ & $\star$ & $\star$ \\
\hline Tenure/use rights are well defined and upheld. & $\star$ & $\star$ & $\star$ & $\star$ & $\star$ & $\star$ \\
\hline Forest dependent people share in economic benefits of forest utilization. & & $\star$ & $\star$ & $\star$ & $\star$ & \\
\hline $\begin{array}{l}\text { Opportunities exist for local people/forest dependent people to get employment and } \\
\text { training from forest company. }\end{array}$ & & $\star$ & $\star$ & $\star$ & & \\
\hline \multicolumn{7}{|l|}{$\begin{array}{l}\text { (implied) Stakeholders, Including Forest Actors, Have a Voice In Forest } \\
\text { Management. }\end{array}$} \\
\hline Stakeholders/local populations participate in forest management. & & $\star$ & $\star$ & $\star$ & $\star$ & \\
\hline $\begin{array}{l}\text { Effective mechanisms exist for two way communication related to forest } \\
\text { management among stakeholders. }\end{array}$ & & $\star$ & $\star$ & $\star$ & & \\
\hline $\begin{array}{l}\text { Forest dependent people and company officials understand each other's plans and } \\
\text { interests. }\end{array}$ & & $\star$ & $\star$ & $\star$ & & \\
\hline $\begin{array}{l}\text { Forest dependent people/stakeholders have the right to help monitor forest } \\
\text { utilization. }\end{array}$ & & $\star$ & $\star$ & $\star$ & & \\
\hline Conflicts are minimal or settled. & & $\star$ & $\star$ & $\star$ & $\star$ & \\
\hline
\end{tabular}




\section{PART 9}

\section{Criteria and Indicators: A Proposal}

"SIMPLICITY, SIMPLICITY, SIMPLICITY! I SAY, let your affairs be as two or three, and not a hundred or a thousand; instead of a million count half a dozen, and keep your accounts on your thumb-nail."

- Henry David Thoreau, US philosopher, author, naturalist, 1854

"A tree's A tRee. How many more do you need to look at?" - Ronald Reagan, US Republican politician, president, 1965

$\mathrm{S}$ OMETIMES LESS IS MORE. Rational behavior, when it comes to the design of criteria and indicators, dictates that we keep our indicator sets manageable in scale. To be useful as a diagnostic or planning tool, rationality also implies that individual indicators should, where possible, address unambiguous economic goals or intervention points.

\section{A Negative List}

In operationalizing criteria and indicators, some flexibility is required. In general, analysts working at a local level find that it may be desirable to substitute one indicator for another, or one verifier for another, if the 'pro forma' recommended measures do not seem to be available. If a handbook recommends gathering information on 'years of employment', but if the best data that are locally available report 'households dependent on forestry' (which is what Vietnamese statistical agencies report), then little will be lost in substituting one indicator for another.

In general, we acknowledge that such substitution is often necessary or desirable, and we would encourage local managers to find locally appropriate information. There is, however, a danger of writing a carte blanche by encouraging such substitution. We therefore feel compelled to list a few indicators that, for various reasons, should not be used, even though it has in some cases become fashionable to try to measure or otherwise estimate them. We call this our 'negative list', and it is relatively brief.

First, internal rate of return should be abandoned as an indicator of anything. It does not properly account for alternative investments, it is frequently miscalculated, and it is methodologically inferior to any number of other indicators that measure profitability or feasibility. All of the data required to calculate an IRR can equally well be used to calculate, for example, rent margins, which provide a clearer picture of economic efficiency or sustainability of a firm.

Second, one should not attempt economic valuation of global functions such as biodiversity maintenance or carbon sequestration, and of regional ecosystem functions such as soil fertility maintenance, watershed protection, or local climate regulation (windbreaks, shade, etc.) Such valuations are too complex to be applied accurately and regularly at a stand level; other simpler physical measures relating to stand size and integrity can provide equivalent information content that is easier and less costly to monitor. Valuation is not always necessary to understand the economic importance of a given ecological service.

Third, we discourage the use of complex economic distribution indices and coefficients as indicators or verifiers of equity concerns. Measures such as the Gini coefficient or Atkinson Index provide important informational content for national level planning, but their accurate estimation at a stand level is difficult and requires special training to insure that the measures are properly represented. Again, other measures of equity, such as forest rents accruing to local populations, are easier to estimate and provide richer informational content.

\section{A Positive List}

A potential 'positive list' of economic C\&I has been compiled in Table 5. The list reflects the broader needs to address efficiency, equity, sustainability and a precautionary stance in FMU management. What is perhaps notable about this list is that does not necessarily involve a lot of economic calculations relating to pricing and values: many $\mathrm{C} \& \mathrm{I}$ that are of economic relevance can be represented through simply physical measures or verifiers. 
This particular list of $\mathrm{C} \& \mathrm{I}$ was derived by examining many case studies that analyzed the causes of destructive forestry practices in various regions of the world. The cases were drawn from the published economics literature, and from official reports by international development agencies. The studies identify the economic policies - forestry and non-forestry - that have repeatedly created incentives inimical to SFM (see Annex A). The C\&I indicators in Table 5 are those which would signal the existence of such policies, and would suggest the direction and intervention points for remedial actions.

Finally, examinations of unsustainable forestry typically neglect the need for mechanisms to manage the effects of unexpected shocks. The ability to adapt to changing circumstances has been found to be critical in most systems - both natural and man-made. Consequently, we have included 'resilience' indicators in our set.

Adoption of this set, or of any similar set, will still leave open a number of underlying methodological and interpretive questions. To what extent are individual indicators self-standing? To what extent does their interpretation depend on an external context potentially influenced by ideological perspectives? To what extent do they permit unambiguous analysis against given thresholds? Do they require further elaborate interpretation in a complex modeling environment? Can they inform decisions directly or do they need to be interpreted in a multi-criteria framework? Such questions are relevant to all indicator sets, not just economic indicators. It is expected that, as decisionmakers and analysts come to grips with such methodological questions, the role of $\mathrm{C} \& \mathrm{I}$ will become increasingly clear.

In our view, the development of C\&I is itself part of a systemic process of information gathering and analysis, and subsequent trial-and-error decision-making. While C\&I are often regarded as "external" monitors of a forest system, they should more correctly be viewed as an integral "internal" part of the forest system in which adaptive management is informed by existing $C \& I$ while continuously developing new C\&I to meet new management challenges.

\section{Closing Remarks}

In closing, we note that we have often concluded that, from a practical perspective, criteria, indicators, and verifiers are often defined in a negative sense. Efficiency is elusive, so measure inefficiency. Equity is a noble pursuit, but only the inequities will be measurable. Sustainable forest management is still undefined, but we do have some inkling of what might constitute unsustainable management. Absolute order will never exist, so we must use precautionary measures to avoid being caught in the chaos. And we say all of this in the name of rational use of our forest resources.

Therein lies perhaps the greatest irony. It is our eternal curse that, as economists, we must assume rationality. Yet all of our devices allow us only to detect irrationality. 
Table 5. Recommended Criteria \& Indicators

\begin{tabular}{|c|c|c|c|c|c|c|c|c|}
\hline \multirow{2}{*}{\multicolumn{2}{|c|}{ Principle $(\boldsymbol{P})$, Criterion (C), Indicator }} & \multicolumn{3}{|c|}{ Goal } & \multicolumn{3}{|c|}{$\begin{array}{l}\text { Intervention } \\
\text { Point }\end{array}$} & \multirow{3}{*}{ 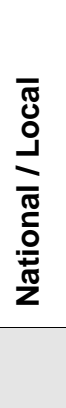 } \\
\hline & & \multirow{2}{*}{ 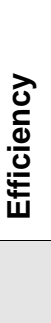 } & \multirow{2}{*}{ 站 } & \multirow{2}{*}{ 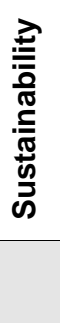 } & \multirow{2}{*}{$\begin{array}{l}\text { D } \\
\text { त } \\
\text { ஸे }\end{array}$} & \multirow{2}{*}{ 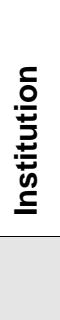 } & \multirow{2}{*}{$\frac{\text { do }}{\frac{7}{0}}$} & \\
\hline$P 1$ & $\begin{array}{l}\text { Precautionary measures promote system resilience to uncertain } \\
\text { shocks. }\end{array}$ & & & & & & & \\
\hline \multirow[t]{2}{*}{ C1.1 } & Precautionary management structures in place. & & & & & & & \\
\hline & Existence of broad-based adaptive management plan & & & $\star$ & $\star$ & & & L \\
\hline \multirow[t]{3}{*}{ C1.2 } & Precautionary economic policies in place. & & & & & & & \\
\hline & Reserve funds available for damage (performance bond) & & & $\star$ & $\star$ & & $\star$ & $\mathrm{N}, \mathrm{L}$ \\
\hline & Anti-corruption provisions in place & $\star$ & $\star$ & $\star$ & $\star$ & $\star$ & $\star$ & $\mathrm{N}, \mathrm{L}$ \\
\hline \multirow[t]{3}{*}{ C1.3 } & Existence of a functioning buffer zone. & & & & & & & \\
\hline & Low levels of conflict at FMU boundary & & & $\star$ & $\star$ & & & $\mathrm{L}$ \\
\hline & Existence of economic development authority in buffer zone & & & $\star$ & & $\star$ & & $\mathrm{N}, \mathrm{L}$ \\
\hline$P 2$ & Forest estate and forest use options are maintained. & & & & & & & \\
\hline \multirow[t]{5}{*}{ C2.1 } & Legal framework protects forest resources $\&$ access. & & & & & & & \\
\hline & $\begin{array}{l}\text { Security of tenure (includes status of length, exclusivity, } \\
\text { enforceability, transferability) }\end{array}$ & $\star$ & $\star$ & $\star$ & $\star$ & $\star$ & $\star$ & $\mathrm{N}, \mathrm{L}$ \\
\hline & Existence of non-confiscatory land use policy & & & $\star$ & & $\star$ & $\star$ & $\mathrm{N}$ \\
\hline & $\begin{array}{l}\text { Existence of property rights for exploited non-timber forest products } \\
\text { (e.g. fuelwood) }\end{array}$ & $\star$ & $\star$ & & & $\star$ & $\star$ & $\mathrm{N}, \mathrm{L}$ \\
\hline & Land tenurial prerequisite policy does not discriminate against forestry & & & $\star$ & & $\star$ & $\star$ & $\mathrm{N}, \mathrm{L}$ \\
\hline \multirow[t]{5}{*}{ C2.2 } & Forest migration pressure is minimized. & & & & & & & \\
\hline & Land use policy recognized by local forest dwellers & & & $\star$ & $\star$ & $\star$ & $\star$ & $\mathrm{L}$ \\
\hline & Road density in forested area does not promote encroachment & & & $\star$ & $\star$ & $\star$ & & $\mathrm{L}$ \\
\hline & Agricultural research and extension stabilizes population & $\star$ & & $\star$ & $\star$ & $\star$ & $\star$ & $\mathrm{N}, \mathrm{L}$ \\
\hline & Forestry research and extension stabilizes population & $\star$ & & $\star$ & $\star$ & $\star$ & $\star$ & $\mathrm{N}, \mathrm{L}$ \\
\hline \multirow[t]{7}{*}{ C2.3 } & Non-forestry policies do not distort forest management. & & & & & & & \\
\hline & Absence of agricultural sector incentives for production expansion & $\star$ & & $\star$ & & & $\star$ & $\mathrm{N}$ \\
\hline & Absence of price controls on domestic food production & $\star$ & & $\star$ & & & $\star$ & $\mathrm{N}$ \\
\hline & Presence of alternative fuel oils in forest boundary areas & & & $\star$ & & $\star$ & $\star$ & $\mathrm{N}$ \\
\hline & Absence of price controls on fuel oils & $\star$ & & $\star$ & & & $\star$ & $\mathrm{N}$ \\
\hline & Absence of distorting resettlement policies & $\star$ & & $\star$ & & & $\star$ & $\mathrm{N}$ \\
\hline & Absence of distorting exchange rate over- or under-valuation & $\star$ & & $\star$ & & & $\star$ & $\mathrm{N}$ \\
\hline \multirow[t]{4}{*}{ C2.4 } & Demonstrated forest management capability. & & & & & & & \\
\hline & Government enforcement of land use policy & & & $\star$ & $\star$ & $\star$ & & $\mathrm{N}, \mathrm{L}$ \\
\hline & Local respect for FMU boundary & & & $\star$ & $\star$ & & & $\mathrm{L}$ \\
\hline & Concessionaire efforts to protect FMU boundaries & & & $\star$ & $\star$ & & & $\mathrm{L}$ \\
\hline \multirow[t]{2}{*}{ C2.5 } & Demonstrated reinvestment in forest-use options. & & & & & & & \\
\hline & Absence of excessive capital mobility (promoting 'cut and run') & $\star$ & & $\star$ & $\star$ & & & L \\
\hline \multirow[t]{2}{*}{ C2.6 } & Externalities of forestry practices are minimized. & & & & & & & \\
\hline & Absence of off-site impacts & & & $\star$ & $\star$ & $\star$ & $\star$ & $\mathrm{L}$ \\
\hline
\end{tabular}


Table 5. (con'd) Recommended Criteria \& Indicators

\begin{tabular}{|c|c|c|c|c|c|c|c|c|}
\hline \multirow{2}{*}{\multicolumn{2}{|c|}{ Principle $(P)$, Criterion $(C)$, Indicator }} & \multicolumn{3}{|c|}{ Goal } & \multicolumn{3}{|c|}{$\begin{array}{l}\text { Intervention } \\
\text { Point }\end{array}$} & \multirow{2}{*}{ 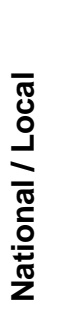 } \\
\hline & & \multirow{2}{*}{ 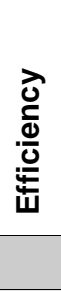 } & \multirow{2}{*}{$\frac{\text { Z) }}{\frac{7}{3}}$} & \multirow{2}{*}{ 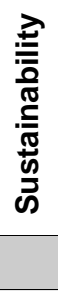 } & & & & \\
\hline P3 & Intragenerational equity is enhanced. & & & & & & & \\
\hline \multirow[t]{5}{*}{ C3.1 } & Equitable access to economic values. & & & & & & & \\
\hline & Transparent system of concession allocation & $\star$ & $\star$ & & $\star$ & $\star$ & $\star$ & $\mathrm{N}$ \\
\hline & Access of small timber operators to timber concessions & $\star$ & $\star$ & & $\star$ & $\star$ & & $\mathrm{N}, \mathrm{L}$ \\
\hline & Access of non-timber users to non-timber forest products & & $\star$ & & $\star$ & $\star$ & $\star$ & L \\
\hline & Employment of local population in forest management & & $\star$ & $\star$ & $\star$ & & & $\mathrm{L}$ \\
\hline \multirow[t]{2}{*}{ C3.2 } & Equitable access to economic decision-making. & & & & & & & \\
\hline & Participation of local interest groups in management planning. & & & $\star$ & $\star$ & $\star$ & & $\mathrm{L}$ \\
\hline \multirow[t]{4}{*}{ C3.3 } & Equitable distribution of economic rent. & & & & & & & \\
\hline & Estimated government rent capture & $\star$ & $\star$ & & $\star$ & $\star$ & $\star$ & $\mathrm{N}, \mathrm{L}$ \\
\hline & Estimated operator (manager) rent capture & $\star$ & $\star$ & & $\star$ & $\star$ & $\star$ & L \\
\hline & Estimated local forest-dweller rent capture & $\star$ & $\star$ & & $\star$ & $\star$ & $\star$ & L \\
\hline \multirow[t]{2}{*}{ C3.4 } & Off-site negative impacts are compensated. & & & & & & & \\
\hline & Number of people affected by off-site impacts, without compensation & $\star$ & $\star$ & & $\star$ & & $\star$ & L \\
\hline P4 & Forest management is socially efficient. & & & & & & & \\
\hline \multirow[t]{2}{*}{ C4.1 } & Presence of economic rent. & & & & & & & \\
\hline & Total harvesting revenues exceed harvesting costs & $\star$ & & & $\star$ & $\star$ & & L \\
\hline \multirow[t]{2}{*}{ C4.2 } & Product mix is optimal and equitable. & & & & & & & \\
\hline & $\begin{array}{l}\text { Diversification of total forest product utilization (products used/known } \\
\text { potential products) }\end{array}$ & $\star$ & $\star$ & $\star$ & $\star$ & $\star$ & $\star$ & $\mathrm{N}, \mathrm{L}$ \\
\hline \multirow[t]{5}{*}{ C4.3 } & Timber extraction is efficient. & & & & & & & \\
\hline & $\begin{array}{l}\text { Diversification of timber product utilization (no. of species cut/potential no. } \\
\text { of species cut) }\end{array}$ & $\star$ & & & $\star$ & $\star$ & $\star$ & $\mathrm{N}, \mathrm{L}$ \\
\hline & Utilization of secondary and lower grade species & $\star$ & & & $\star$ & $\star$ & $\star$ & $\mathrm{N}, \mathrm{L}$ \\
\hline & Annual extraction as \% of estimated annual growth of residual stand & $\star$ & & $\star$ & $\star$ & & & L \\
\hline & Volume extracted/ha (re: logging at extensive margin) & $\star$ & & & $\star$ & & $\star$ & $\mathrm{L}$ \\
\hline \multirow[t]{6}{*}{ C4.4 } & Timber processing is efficient. & & & & & & & \\
\hline & High use rates of local wood processing capacity & $\star$ & & $\star$ & & $\star$ & $\star$ & $\mathrm{N}, \mathrm{L}$ \\
\hline & Obligations made to concessionaires to process their full production & $\star$ & & & & $\star$ & $\star$ & $\mathrm{N}, \mathrm{L}$ \\
\hline & Efficient domestic market for logs and semi-processed wood & $\star$ & & & & $\star$ & $\star$ & $\mathrm{N}, \mathrm{L}$ \\
\hline & Low waste ratios in processing & $\star$ & & & & $\star$ & $\star$ & $\mathrm{N}, \mathrm{L}$ \\
\hline & Efficient equivalence of domestic log price/export log price & $\star$ & & & $\star$ & & $\star$ & $\mathrm{N}, \mathrm{L}$ \\
\hline \multirow[t]{3}{*}{ C4.5 } & Forest productivity is maintained & & & & & & & \\
\hline & Low residual stand damage & $\star$ & & & $\star$ & & & L \\
\hline & No premature stand reentry (re: logging at intensive margin.) & $\star$ & & $\star$ & $\star$ & & $\star$ & $\mathrm{L}$ \\
\hline \multirow[t]{3}{*}{ C4.6 } & Efficient exploitation of NTFPs. & & & & & & & \\
\hline & Commercial development of NTFPs & $\star$ & & $\star$ & $\star$ & $\star$ & $\star$ & $\mathrm{L}$ \\
\hline & Extensive local use of NTFPs & $\star$ & & $\star$ & $\star$ & & & $\mathrm{L}$ \\
\hline
\end{tabular}




\section{Notes}

\section{Acronyms}

$\begin{array}{ll}\text { AAC } & \text { Annual Allowable Cut } \\ \text { ATO } & \text { African Timber Organization } \\ \text { BCR } & \text { Benefit Cost Ratio } \\ \text { C\&I } & \text { Criteria and Indicators } \\ \text { CBA } & \text { Cost Benefit Analysis } \\ \text { CFI } & \text { Continuous Forest Inventory } \\ \text { CIFOR } & \text { Center for International Forestry Research } \\ \text { FMU } & \text { Forest Management Unit } \\ \text { FSC } & \text { Forest Stewardship Council } \\ \text { GNP } & \text { Gross National Product } \\ \text { HRD } & \text { Human Resource Development } \\ \text { IIED } & \text { International Institute for Environment and } \\ & \text { Development } \\ \text { IRR } & \text { Internal Rate of Return } \\ \text { ITTO } & \text { International Tropical Timber Association } \\ \text { ITW } & \text { Initiative Tropenwald (Initiative on Tropical } \\ & \text { Forests) } \\ \text { LEI } & \text { Lembaga Ekolabel Indonesia (Indonesian } \\ & \text { Ecolabeling Institute) } \\ \text { NTFP } & \text { Non Timber Forest Products } \\ \text { NPV } & \text { Net Present Value } \\ \text { NREA } & \text { Natural Resource and Environmental } \\ & \text { Accounting } \\ \text { OECD } & \text { Organisation for Economic Cooperation and } \\ & \text { Development } \\ \text { PFE } & \text { Permanent Forest Estate } \\ \text { SFM } & \text { Sustainable Forest Management } \\ \text { SNA } & \text { System of National Accounts } \\ \text { SW } & \text { SmartWood (Natural Forest Management } \\ & \text { Guidelines) } \\ \text { TP } & \text { Tarapoto Proposal } \\ \text { UNSO } & \text { United Nations Statistical Office } \\ \text { WM } & \text { Woodmark (Responsible Forestry } \\ & \text { Programme of the Soil Association, Bristol, } \\ \text { UK) }\end{array}$

\section{Citations}

Bagehot, Walter (1826-77), English economist, critic. Physics and Politics, ch. 2, sct. 3 (1872).

Camus, Albert (1913-60), French-Algerian philosopher, author. The Rebel, pt. 4, "Creation and Revolution" (1951; tr. 1953).

de La Fontaine, Jean (1621-95), French poet, fabulist. Moral of fable, "La Fortune et le Jeune Enfant," in Fables, bk. 5, no. 11 (1678-79).

Dietrich, Marlene (1904-92), German-born US film actor. Marlene Dietrich's ABC, "Earning” (1962).

Eisenhower, Dwight D. (1890-1969), US general, Republican politician, president. One of Eisenhower's favorite maxims. Quoted by Richard Nixon in: Six Crises, "Krushchev" (1962).

Emerson, Ralph Waldo (1803-82), US essayist, poet, philosopher. Essays, "Gifts" (Second Series, 1844).

Franklin, Benjamin (1706-90), US statesman, writer. Letter, 13 Nov. 1789 (published in Complete Works, vol. 10, ed. by John Bigelow, 1887-88).

Gandhi, Mohandas K. (1869-1948), Indian political, spiritual leader. Young India (14 Oct. 1926).

Hegel, Georg (1770-1831), German philosopher. The Philosophy of History, "Introduction," sct. 3 (1837).

Jevons, W. Stanley (1835-82), British economist, logician. Investigations in Currency and Finance, pt. 2, ch. 4 (1884).

Keynes, John Maynard (1883-1946), British economist. Essays in Persuasion, ch. 5, “The Future,” (1931).

Lennon, John (1940-80), British rock musician. TwentyFour Hours, 15 Dec. 1969, BBC-TV.

Leopold, Aldo (1886-1948), US forester. Quoted in: Stewart L. Udall, The Quiet Crisis, ch. 14 (1963).

Locke, John (1632-1704), English philosopher. Second Treatise on Civil Government, ch. 6 (written 1681; published 1690).

Reagan, Ronald (b. 1911), US Republican politician, president. Speech, 12 Sept. 1965. Quoted in: Sacramento Bee (California, 12 March 1966). Reagan later denied having made this statement.

Saul, John Ralston (b. 1947). The Unconscious Civilization. Anansi Press: Concord, Ontario. p. 4. (1995)

Seneca (c. 5 B.C.-A.D. c. 65), Roman writer, philosopher, statesman. Attributed, in Noctes Atticae, bk. 12, ch. 2, sct. 13, by second-century Roman grammarian Aulus Gellius. 
Stein, Gertrude (1874-1946), US author. Everybody's Autobiography, ch. 3 (1937).

Sting [Gordon Matthew Sumner] (b. 1951), British rock musician. International Herald Tribune (Paris, 14 April 1989).

Thoreau, Henry David (1817-62), US philosopher, author, naturalist. Walden, "Where ILived, and What I Lived For" (1854).

Weil, Simone (1909-43), French philosopher, mystic. "La Rationalisation" (written 1937; published in La Condition Ouvrière, 1951).

Wilde, Oscar (1854-1900), Anglo-Irish playwright, author. Lord Henry Wotton, in The Picture of Dorian Gray, ch. 4 (1891). Original was: "Nowadays people know the price of everything and the value of nothing."

\section{Glossary}

Words in this document are used as defined in most standard English language dictionaries. The precise meaning and local interpretation of certain phrases should be decided in the local context by forest managers. In this document, the words below are understood as follows:

Biological diversity. The variability among living organisms from all sources including, inter alia, terrestrial, marine and other aquatic ecosystems and the ecological complexes of which they are a part; this includes diversity within species, between species and of ecosystems.

Biological diversity values. The intrinsic, ecological, genetic, social, economic, scientific, educational, cultural, recreational and aesthetic values of biological diversity and its components.

Criterion. Used in the definition of C\&I by CIFOR: A principle or standard that a thing is judged by. It can be seen as a 'second order' principle that adds meaning or operationality to a principle without being a direct yardstick of performance.

Ecosystem. A community of all plants and animals and their physical environment, functioning together as an interdependent unit.

Efficiency. In its economic sense, a condition in which benefits less costs are maximized. Social efficiency relates to a situation where benefits and costs are those to society as a whole, in contrast to private efficiency which will reflects benefits and costs accruing only to a single individual or firm.
Endangered species. Any species which is in danger of extinction throughout all or a significant portion of its range.

Exotic species. An introduced species not native or endemic to the area in question.

Forest integrity. The ability of a forest to maintain its composition, dynamics, functions and structural attributes.

Forest management unit (FMU). A clearly demarcated area of land covered predominantly by forests, managed to a set of explicit objectives and according to a long-term management plan. An FMU can usually be expected to cover a few hundred to several hundred thousand hectares. The entire area of the FMU has to be clearly demarcated on the ground and usually also on a map. Under the broad objectives to which the entire management unit is subjected, sub-units may be managed under different and separate management regimes. The management plan will usually be written and may sometimes be published. However, neither are necessary conditions.

Gini coefficient. A measure of concentration or distribution often used to represent a measure of inequality. Originally used to measure industrial concentration; currently more commonly used to measure income inequality. If all individuals in a sample have equal income, then Gini $=0$. If all income is concentrated in one individual, Gini=1.

Indicator. Used in the definition of C\&I by CIFOR: Any variable or component of the forest ecosystem or relevant management systems used to infer sustainability of resource and its utilization.

Indigenous lands and territories. The total environment of the lands, air, water, sea, sea-ice, flora and fauna, and other resources which indigenous peoples have traditionally owned or otherwise occupied or used.

Keystone species. A species that affects the survival and abundance of many other species in an ecosystem.

Landscape. A geographical mosaic composed of interacting ecosystems resulting from the influence of geological, topographical, soil, climatic, biotic and human interactions in a given area.

Native species. A species that occurs naturally in the region.

Natural cycles. Biogeochemical cycling as a result of interactions between soils, water, plants, and animals in forest environments that affect the ecological productivity of a given site.

Natural forest. Forest areas where most of the principal characteristics and key elements of native ecosystems 
such as complexity, structure and diversity are present

Non-timber forest products. All forest products except timber, including other materials obtained from trees such as resins and leaves, as well as any other plant and animal products.

Primary forest. An ecosystem characterized by an abundance of mature trees, relatively undisturbed by human activity. Human impacts in such forest areas have normally been limited to low levels of hunting, fishing and harvesting of forest products, and, in some cases, to low density, shifting agriculture with prolonged fallow periods. Such ecosystems are also referred to as "mature," "old-growth" or "virgin" forests.

Principle. Used in the definition of C\&I by CIFOR: A fundamental truth or law as the basis of reasoning or action. Principles in the context of sustainable forest management are seen as providing the primary framework for managing forests in a sustainable fashion.

Residual Forest. Group of trees remaining after the primary (or secondary) forest is logged. Trees in the residual forest include seed trees (for formation of the next stand), crop trees (for the next production period), overmature trees (those without economic value but possibly with high ecological value), and protected tree species (designated as such by national law or international agreement).

Secondary forest. The ecosystems that regenerate from a substantial disturbance (flood, fire, land clearing or extensive and intensive logging) characterized by a scarcity of mature trees and an abundance of pioneer species and a dense understorey of saplings and herbaceous plants. Although secondary forests frequently peak in terms of biomass accumulation well-within one felling cycle, the transition to primary forests usually requires several rotation lengths, depending upon the severity of the original disturbance. Irreversible transformation of the underlying soil and nutrient cycle brought about by chronic or intense use may render it impossible for the original, primary forest type to return.

Silviculture. The science and art of managing a forest by manipulating its establishment, composition and growth to best fulfill the objectives of the owner. This may, or may not, include timber production.

Succession. Progressive changes in species composition and forest community structure caused by ecological processes over time.

Tenure. Socially defined agreements held by individuals or groups, recognized by legal statutes or customary practice, regarding the "bundle of rights and duties" of ownership, holding, access and/or usage of a particular land unit or the associated resources there within (such as individual trees, plant species, water and minerals).

Use rights. Rights for the use of forest resources that can be defined by local custom, mutual agreements, or prescribed by other entities holding access rights. These rights may restrict the use of particular resources to specific levels of consumption or particular harvesting techniques.

Verifier. Used in the definition of C\&I by CIFOR: Data or information that enhances the specificity or the ease of assessment of an indicator. This can take the form of a tolerance level or performance threshold (relating to some guideline), or the means of verification, which is often linked to a verification procedure.

\section{References}

Amacher, Gregory S. 1997. The Design of Forest Taxation: A Synthesis of New Directions. Silva Fennica 31(1): 101-119.

Andersen, Lykke E. 1997. A Cost-Benefit Analysis of Deforestation in the Brazilian Amazon. Institute for Applied Economic Research. Rio de Janeiro: Brazil.

Andersen, Lykke E. 1997. Modelling the Relationship Between Government Policy, Economic Growth, and Deforestation in the Brazilian Amazon. Working Paper No. 1997-2. University of Aarhus: Denmark.

Andersen, Lykke E., Clive W. J. Granger, Ling-Ling Huang, Eustaquio J. Reis, and Diana Weinhold 1996. Report on Amazon Deforestation. Discussion Paper No. 96-40. University of California: San Diego.

Bennet, C. P. A. and R.N. Byron 1997. Draft. Valuing Resource Valuation: Exploring the Role of Quantitative Valuation of Indonesia's Forest Resources. Paper prepared for Center for International Forestry Research (CIFOR) Workshop: Valuing Resource Valuation. December 1997.

Blackwood, D.L. and Lynch, R.G. 1994. The measurement of inequality and poverty: a policy maker's guide to the literature. World Development 22(4): 811-822.

Boado, Eufresina L. 1988. Incentive policies and forest use in the Philippines. In: Public Policies and the Misuse of Forest Resources. Edited by: Robert Repetto and Malcolm Gillis. World Resources Institute: Washington. 
Bogahawatte, C. 1997. Non Timber Forest Products and Rural Economy in Conservation of Wet Zone Forests in Sri Lanka. Department of Agricultural Economics, University of Peradeniya: Sri Lanka.

Costanza, R., d'Arge, R., de Groot, R., Farber, S., Grasso, M., Hannon, B., Limburg, K., Naeem, S., O’Neill, R.V., Paruelo, J., Raskin, R.G., Sutton, P., van den Belt, M. 1997. The value of the world's ecosystem services and natural capital. Nature 387: 253.

Cruz, Wilfrido, Herminia Francisco, and Gregory Amacher. 1997. Poverty, migration, and deforestation in the Philippines. In: The Greening of Economic Policy Reform, Volume II Case Studies. Edited by: Wilfrido Cruz, Mohan Munasinghe and Jeremy J. Warford. World Bank: Washington.

Daly, H. and J. Cobb Jr. 1994, For the Common Good. Beacon Press: Boston.

Drengson, A. and D. Taylor. Eds. 1997. Ecoforestry: The Art and Science of Sustainable Forest use. New Society Publishers: Gabriola Island, BC and Stony Creek, CT.

Drepper, F.R., and Månsson, B.Å. 1993. Intertemporal valuation in an unpredictable environment. Ecological Economics, 7.

Faucheux, S. and G. Froger. 1995. Decision-making under environmental uncertainty. Ecological Economics 15:29-42.

Gillis, Malcolm. 1988. Indonesia: Public policies, resource management, and the tropical forest. In: Public Policies and the Misuse of Forest Resources. Edited by: Robert Repetto and Malcolm Gillis. World Resources Institute: Washington.

Gillis, Malcolm. 1992. Forest concession management and revenue policies. In Managing the World's Forests. Edited by Narendra P. Sharma. World Bank, Washington.

Goodland, Robert and Herman Daly. 1996. If tropical $\log$ export bans are so perverse, why are there so many? Ecological Economics 18, 189-196.

Green, T.L. 1998. Accounting for Natural Capital in British Columbia: Forestry and Conflict in the Slocan Valley. Master's Thesis, University of Victoria: Victoria.

Grut, Mikael, Nicolas Egli, and John A. Gray. 1990. Forest Revenue Systems and Concession Management Policies for West and Central Africa Moist Forests. Unpublished Working Paper. World Bank: Washington.

Gustavson, K., S. Lonergan and J. Ruitenbeek. 1998. Selection and modeling of sustainability development indicators: A case study of the Fraser River Basin, British Columbia. Ecological Economics [in press].

Haley, David and Martin Luckert. 1995. Policy instruments for sustainable development in the British Columbia forestry sector. In Managing Natural Resources in British Columbia. Edited by Anthony Scott, John Robinson, David Cohen. University of British Columbia Press: Vancouver.

Hamilton, Clive. 1997. The sustainability of logging in Indonesia's tropical forests: A dynamic input-output analysis. Ecological Eonomics 21 (1997) 183-195.

Hammond , H., S. Hammond and T. Bradley. 1994. Ecosystem-based planning to protect biodiversity, domestic watersheds and the economy in the Slocan Valley of British Columbia, Canada. Paper presented to the Thirds International Conferences of Ecological Economics, 24-28 October, San José, Costa Rica.

Hicks, John. 1946. Value and Capital: An Inquiry into Some Fundamental Principles of Economic Theory. Clarendon Press: Oxford.

Huber, Richard, Jack Ruitenbeek and Ronaldo Seroa da Motta. 1996. Market Based Instruments for Environmental Policymaking in Latin America and the Caribbean: Lessons from Eleven Countries. World Bank: Washington.

Kellenberg, John. 1995. Accounting for Natural Resources: Ecuador 1971-1990. Doctoral Dissertation. The John Hopkins University Press: Baltimore, Maryland.

Kellenberg, John. 1997. Draft. Addressing Global Externalities in Forests and Forestry. Global Overlays Program. World Bank: Washington

Lonergan, S., Ruitenbeek, J., and Gustavson, K. 1996. Selection and Modeling of Indicators for the Fraser River Basin. Occasional Paper Series 8, State of the Environment Directorate, Environment Canada/ State of the Environment Reporting, BC Ministry of Environment, Lands and Parks. Ottawa/Victoria.

Lopez, Ramon. 1997. Evaluating economywide policies in the presence of agricultural environmental externalities: The case of Ghana. In The Greening of Economic Policy Reform. Volume II: Case Studies. Edited by Wilfrido Cruz, Mohan Munasinghe and Jeremy Warford. World Bank: Washington.

Manzetti, Luigi. 1994. Economic Reform and Corruption in Latin America. North-South Issues, North-South Center, University of Miami, 3:1-6.

Markandya, A., and Pearce, D. 1988. Environmental Considerations and the Choice of Discount Rates in 
Developing Countries. Environment Department Working Paper No. 3, World Bank: Washington, DC.

Mercer, D. Evan and John Soussan. 1992. Fuelwood problems and solutions. In Managing the World's Forests. Edited by Narendra P. Sharma. International Band for Reconstruction and Development, 1992.

Munasinghe, Mohan and Wilfrido Cruz. 1995. Economywide Policies and the Environment: Lessons from Experience. World Bank Environment Paper Number 10. World Bank: Washington.

Munasinghe, Mohan. 1993. Environmental Economics and Sustainable Development. World Bank Environment Paper Number 3. World Bank: Washington.

Norgaard, R.B., and Howarth, R.B. 1991 Sustainability and discounting the future, in Costanza, R. ed. Ecological Economics: The Science and Management of Sustainability. Columbia University Press: New York.

OECD. 1997. "Convention on Combating Bribery of Foreign Public Officials in International Business Transactions," OECD: Paris, 18 December.

Perrings, C. 1991. Reserved rationality and the precautionary principle: Technological change, time and uncertainty in environmental decision-making, in Costanza, R. ed. Ecological Economics: The Science and Management of Sustainability. Columbia University Press: New York.

Persson, Annika and Mohan Munasinghe. 1997. Natural resource management and economywide policies in Costa Rica: A computable general equilibrium (GE) modeling approach. In The Greening of Economic Policy Reform. Volume II: Case Studies. Edited by Wilfrido Cruz, Mohan Munasinghe and Jeremy Warford. World Bank: Washington.

Potvin, J. 1992. Indicators of Ecologically Sustainable Development: Synthesized Workshop Proceedings. Canadian Environmental Advisory Council: Ottawa.

Prahbu, Ravi, Carol J. P. Colfer and Richard G. Dudley. 1997. Draft. Guidelines for Developing, Testing \& Selecting Criteria and Indicators for Sustainable Forest Management. Center for International Forestry Research (CIFOR).

Repetto, Robert and Malcolm Gillis. Eds. 1988. Public Policies and the Misuse of Forest Resources. World Resources Institute.

Repetto, Robert. 1988. The Forest for the Trees? Government Policies and the Misuse of Forest Resources. World Resources Institute. 1988.

Ruitenbeek, H.J. 1991. Indicators of Ecologically Sustainable Development: Towards New
Fundamentals. Canadian Environmental Advisory Council, Ottawa.

Ruitenbeek, H.J. 1993. Infrastructure and the Environment: Lessons and Directions. World Bank, Washington, D.C.

Ruitenbeek, H.J. 1996. Valuation and distribution of ecological entitlements in the forest zone of Cameroon: Implications for economic and environmental security. Ecological Economics 17: 49-64.

Sadoff, Claudia. 1993. Natural Resource Accounting: A Case Study of Thailand's Forest Management. Doctoral Dissertation. University of California: Berkeley.

Schleifer, A. and Vishney, R.W. 1993. Corruption. Quarterly Journal of Economics 108:599-617.

Sen, A. 1992. Inequality Reexamined. Clarendon Press, Oxford.

Sen, A. 1993. The economics of life and death. Scientific American May, 40-47.

Serrao, Emmanuel A. S., Daniel Nepstad, and Robert Walker. 1996. Upland Agriculture and Forestry Development in the Amazon: Sustainability, Criticality and Resilience. Ecological Economics 18 (1996) 3-13.

Southgate, Douglas. 1992. Policies contributing to agricultural colonization of Latin America's tropical forests. In Managing the World's Forests. Edited by Narendra P. Sharma. World Bank, Washington.

Tacconi, L. 1997. An ecological economic approach to forest and biodiversity conservation: The case of Vanuatu. World Development 25:1995-2008.

Tognetti, Sylvia S., R. Costanza, L. Arizpe, C. Cleveland, H. Daly, A., Gupta, J. Martinez-Alier, P.H. May, M. Ritchie, H.J. Ruitenbeek and O. Segura. 1995. Poverty and the Environment: Reconciling Short-Term Needs with Long-Term Sustainability Goals. United Nations Environment Programme: Nairobi.

Tognetti, Sylvia S. 1997. Integrated Ecological and Economic Models and Indicators for Sustainable Development - A Preliminary Literature Review. Prepared for SCOPE/UNEP Project on Adaptive Ecological Modeling and Assessment.

United Nations. 1990. SNA Handbook on Integrated Environmental and Economic Accounting. Part I: General Concepts. United Nations: New York.

Vatn, A., L. Bakken, P. Botterweg, and E. Romstad. 1998. Eco-Eco Modelling from Theory to Practice, draft. 
Vincent, J. R. and Clark S. Binkley. 1992. Forest based industrialization: A dynamic perspective. In Managing the World's Forests. Edited by Narendra P. Sharma. World Bank, Washington.

Vincent, Jeffrey R. and Francois Mergen. Eds. 1987. Natural Management of Tropical Moist Forests: Silvicultural Management Prospects for Sustained Utilization.

Ward, B. and R. Dubois. 1972. Only one Earth: The Care and Maintenance of a Small Planet. Deutsch: London.

Winterbottom, I. 1990. Taking Stock: The Tropical Forestry Action Plan After Five Years. World Resources Institute: Washington.

World Bank, UNDP and FAO. 1996. Forest Policy Assessment: Cambodia. World Bank: Washington.

World Bank. 1997. Performance Indicators for The Pilot Program to Conserve the Brazilian Rain Forest. Discussion Paper Manaus Participants Meeting. Rain Forest Unit, World Bank: Brasilia.

World Development Report. 1992. Development and the Environment. World Bank: Washington.

\section{C\&I Source Documents}

African Timber Organization. 1996. Principles, Criteria and Indicators for the Sustainable Management of African Tropical Forests. Libreville, Gabon. ATO
Carazo, Victor R. 1997. Analysis and Prospects of the Tarapoto Proposal: Criteria and Indicators for the Sustainability of the Amazonian Forest. Proceedings of the XI World Forestry Congress. Antalya, Turkey, October 1997. Volume 6, Topic 37.3. TP

Hahn-Schilling, B., J. Heuveldop, and J. Palmer. 1993. Criteria for an Evaluation of Sustainable Management of Tropical Forests. In: A Comparative Study of Evaluation Systems for Sustainable Forestry Management. J. Heuveldop. Arbeitsbericht, Bundesforschungsanstalt fur Forst-und Holzwirtschaft: Hamburg. ITW

International Timber Trade Organization. 1997. Report on the ITTO Expert Panel on Criteria and Indicators. Appendix 4: Criteria and Indicators for the Measurement of Sustainable Management of Natural Tropical Forests. September. [Reprinted in Prabhu, et al., 1997]. ITTO

Lembaga Ekolabel Indonesia. No date. Principles and Criteria of Sustainable Forestry Management. Obtained December 1997 from the web-page of LEI at http://www.iscom.com/ ekolabel/buku1.doc. LEI

Rainforest Alliance. No date. SmartWood General Guidelines for Assessing Natural Forest Management. New York. Obtained December 1997 from the web-page of Rainforest Alliance at http:// www.rainforest-alliance.org/swr3.html. SmartWood

Soil Association Marketing Company Ltd. 1994. Woodmark. The Soil Association's Certificate of Responsible Forestry: Bristol. Woodmark 


\section{Annex A:}

\section{Policy Links}

Tables A.1 and A.2 contain examples of forestry sector and non-forestry sector policy distortions which affect economic efficiency, equity, and sustainability, at the forest stand. Specific policies are linked to forest resource users in terms of the incentive structures these policies create, and the consequent economic behavior they prompt. The effects of that behavior at the stand level are described in terms of their implications for economic efficiency, equity, and sustainability.

In most cases, a specific policy distortion occurs in conjunction with others but, for clarity, Tables A.1 and A.2 individually describe the linkages and effects of each specific policy. They also account for the governing policy environment in which sectoral policies operate. "Pervasive" or governing policies determine the legal and administrative framework in which forestry and non-forestry policies play-out. When this framework is distorted - as is the case with insecure tenure and weak forestry management institutions - the perverse incentives created by specific policy distortions - such as under-priced timber - are exacerbated.

A quick glance at Tables A.1 and A.2 reveals that the effects of distorted forestry sector policies pertain primarily to issues of equity and economic efficiency. The effects of non-forestry sector policies, which often affect land use allocation, pertain primarily to issues of equity and economic sustainability.

\section{Pervasive Policy Distortions}

\section{Insecure Land Tenure}

Insecure forest land tenure exacerbates nearly every policy distortion. Forest lands are managed primarily for timber production. Without secure tenure, timber operations are typically economically inefficient due to extraction damage, wastage in both timber harvesting and processing, sub-optimal silviculture, and lack of NTFP development.

Most industrial wood is harvested under concession agreements between private logging companies and central or regional governments. Concession periods range from 5 to 20 years, but are tending to shorter periods of 5 to 10 years. A limited number of countries allow the transfer of concessions rights, or guarantee compensation should tenure rights be expropriated. Typically, the agreement states the rules and regulations associated with the concession, but renewal or revocation is subject to a vague criterion of "satisfactory performance." As a result, concessionaires are faced with short insecure tenures which provide them with no incentive to maintain the long-term productivity of the resource. Silviculture activities are either not undertaken or minimally undertaken to meet regulated requirements. Extraction damage to the residual stand is often severe.

Problems of insecure tenure are often compounded by, or caused by, inadequate attention to other longstanding traditional tenurial arrangements. Such conflicts further weaken tenure systems, while decreasing incentives for local populations to manage other components of the resource base (e.g., NTFPs) sustainably.

\section{Weak Forest Management Institutions}

Weak forest management institutions reinforce the problems associated with insecure land tenure and other specific policy distortions because they fail to mitigate the perverse incentives created by each. Arguably, if management institutions were strong and capable, policy distortions, especially those from the forestry sector, would be fewer in the first place. However, even in the face of distortionary policies, if management is strong, extraction damage could be reduced, silviculture could be improved, NTFP production could be increased, information would be more complete. Perhaps most important in terms of sustainability, forest estate boundaries could be enforced if there were stronger forest management institutions.

\section{Specific Distortions - Forestry Sector Policies}

\section{Forest Pricing}

Economic rent accrues to a resource which has scarcity attributes - its supply is fixed in the short or long-term. Rent is, in general, the difference between the social value of the resource and its social costs of extraction. Ideally, economic rent is captured by society. Using proper mechanisms, the level of resource extraction is socially optimal: the marginal opportunity cost of consumption equals the marginal benefits of consumption. If some of the economic rent is not captured by government mechanisms, then that portion of the rent becomes excess profit available to the logging industry: the market price to the private producer in effect exceeds the average total cost of extraction. Furthermore, the existence of excess profit - in the form of a share of the economic rent - often motivates the 
industry to expand its output past the point which would be socially optimal, unless the combination of policies and institutional interventions prevent such excess harvesting.

When economic rent is not captured by the resource owner, the forestry resource is underpriced. Because it is underpriced, the resource is used inefficiently: residual stands are severely damaged by extraction activities, thereby reducing the productive potential of the stand; and processing methods are inefficient with considerable wood wastage. Potential economic rent is squandered, while realized rent accrues as excess profits to concessionaires and processors.

Royalties, fees, and taxes are levied by governments to capture the economic rent associated with the forestry resource. Unfortunately, in most cases the fees and taxes are too low to fully capture the rent, and rent seeking behavior by concessionaires is unabated while revenue generation is too low to finance proper forestry management. Fees and taxes are typically inadequate for several reasons: they are not adjusted for inflation; collection systems are complicated or suffer from a shortage of forestry officials; or rent-seeking behavior is simply accommodated.

\section{Royalty Structures and High-Grading}

Fee structures that underprice forest resources not only encourage over-extraction, they can also encourage "high-grading" - a forest practice which under-utilizes the timber resources of the forest. High-grading involves the cutting of only the most valuable stems in forest. It also involves extensive cutting because depending on stand density a greater area of forest is needed to secure a given volume of timber, than would be the case if loggers did not high-grade.

Low-intensity cutting, high-grading, implies low yields from harvested stands as many commercial trees are left uncut. This reduces the current productivity of the stand and it also reduces the future productivity of the stand. In Southeast Asia, dipterocarp saplings and other immature trees require canopy openings for optimal growth. High-grading means that lower grade mature trees will be bypassed and the canopy may not be opened, impeding the health and productivity of the growing stock. Extensive cutting for high-grading also means that virgin forests are depleted more rapidly and extraction damage is spread over a larger area.

Commonly imposed royalties fall into three categories: specific royalties, ad valorem royalties, and per-tree royalties. All three are typically based on actual log harvests rather than the potential yield of a stand. Specific royalties are applied to the estimated extracted volume; per-tree royalties are simply applied to the number of stems cut; and ad valorem royalties are applied to value.

Specific royalties fall into two categories: uniform and differentiated. With uniform (i.e., undifferentiated) specific royalties, the same royalty is applied to every cubic meter of extracted timber, regardless of the market value and extraction costs of the individual stems. The royalty causes high-grading at its worst. Secondary species and lower grade stems of primary species will be bypassed because their extraction cost plus the royalty exceeds the final market value of the stem.

Specific royalties differentiated by species and location reduce the incentive to high-grade, depending upon the degree of differentiation. The greater the degree of differentiation by species, grade, and location the lesser will be the incentive to high-grade. However, given the information and administrative requirements of such a system, the degree of differentiation is usually insufficient to stop high-grading or to approximate the outcome of the ad valorem royalty system. The greater the degree of differentiation, the greater the difficulty in administering the royalty; uniform specific royalties have been the most commonly used because of their administrative simplicity.

Ad valorem royalties severely reduce the incentive to high-grade. In some countries the royalty is differentiated by species; rarely is the royalty differentiated to reflect extraction costs or world market conditions. Consequently, high-grading is not totally eliminated because the values of different stems - after tax and extraction costs - will still differ.

Per-tree royalties are used in West Africa. The system is simple to administer because it requires no grading or scaling: either stems or stumps are counted. Per-tree royalty systems tend to be highly differentiated according to species and location. Per-tree royalties do not provide a high-grading incentive. Since it is based on stems cut and not volume extracted, loggers are more likely to harvest the larger trees while leaving the younger ones which are not yet worthwhile to harvest. Providing that the royalty is assessed on all trees killed, whether used or not, the royalty should encourage efficient use of all trees cut.

\section{Royalties on Processed Wood Products}

Royalties on processed wood as a means of rent capture are becoming more widely used because they are argued to be administratively simpler: there are fewer processing plants than log dumps. However, if royalties previously applied to roundwood are transferred to processed wood (sawn wood or plywood) by means of an average 
conversion factor, there is a considerable reduction in the log equivalent of the royalty, and there is no incentive to improve processing efficiency. Firms which are vertically integrated benefit from this royalty system applied to processed wood. Unlike firms solely engaged in logging, integrated firms can postpone the payment of royalties until the wood is processed or sold.

\section{Harvesting Rules}

Research is on-going as to the appropriateness of different harvesting regimes in different parts of the world. Depending on the region, there are advocates for clear felling, selective cutting, and gap creation; with varying degrees of silviculture management. Each regime carries implications for the future productivity of the stand. In all regimes, extraction damage is severe when coupled with insecure land tenure arrangements and weak management institutions. Selective logging as a harvesting regime has been widely used in the face of insecure tenure arrangements and poor management institutions and its negative impacts on the stand are well documented.

A "selective logging" harvesting regime involves high extraction damage. Selective logging means the harvest of only those stems above a designated diameter. It causes the high-grading of stands and the disturbance of a larger number of forest parcels to secure a given volume of wood. Selective logging is particularly damaging to residual stands when concessionaires reenter the stand pre-maturely thereby further damaging the growing stock. Stand productivity is also reduced when low-intensity cutting fails to open the canopy enough for shade intolerant commercial species.

\section{Export Taxes, Log Export Bans, and Import Duties on Wood Products}

All of these trade policies have been used to foster domestic wood processing. All three measures shield domestic production from the pressures of international competition, thereby accommodating domestic inefficiencies in processing. Log export bans and export taxes effectively reduce the cost of raw material inputs (logs) to domestic processing industries. Import duties increase the domestic price of foreign produced wood products which would otherwise compete successfully with the domestic substitutes.

Log export bans, export taxes and import duties on competing products, through their effects on input costs or domestic market prices, increase the domestic valueadded of the processed product. The value-added is the difference between the price of the finished good and its raw material inputs. The value added is then dissipated by wages, rent, interest on capital, and profits. The greater the value added, the greater can be the production costs and profits.

Log export bans and export taxes are the most commonly used projectionist trade policies for wood processing. Log export bans now being the most prevalent. By increasing the domestic supply of logs, log export restrictions depress domestic log prices, and domestic processing sports a high rate of return. In effect, resource rents are not being split between concessionaires and the processing mills. The high rate of return in processing attracts investment and countries which have used projectionist policies to foster domestic production now suffer from excess processing capacity due to over-investment. In some areas, domestic processing capacity now exceeds the estimated sustainable yield of the countries' forest estates (Vincent and Binkley 1992).

When the price of logs is artificially low, the scarcity signaling role of price is disabled, and log supplies appear abundant. At the harvesting end, there is no incentive to protect or invest in forests; extraction damage is severe and the estate is simply liquidated. At the processing end, under-priced log inputs foster inefficiencies from low processing recovery rates and forests are liquidated more rapidly than would be the case were processing efficient.

\section{Vertical Integration}

Firms engaged in capital intensive activities have incentives to gain control over resources in order to avoid price instability and supply uncertainty. Companies holding long term licensing arrangements can limit stumpage and log markets. Vertically integrated firms have narrow management goals determined by the most appropriate timber supply profiles for their processing plants. A smaller scale forest industry with many producers is more likely to harvest a broader spectrum of forest products, and consequently would be more diverse in its management practices.

Low license fees encourage stockpiling or hoarding of concessions to keep valuable timber off market and out of the hands of competitors. It would appear that vertical integration coupled with a system of low license fees is a strong recipe for market inefficiencies.

\section{NTFP - Market Failure}

Most governments in charge of public forests neglect NTFPs (rattan, nuts, resins, fuelwood, fruit, honey, silk, meat, etc.) Most do not collect any information on the type and volume of NTFPs. As a result, there is incomplete information about the economic potential of 
NTFPs. Property rights to NTFP are unclear, rendering those products open access resources. In some cases, NTFP extractors have been forced by timber concessionaires to surrender traditional use rights.

All research and indicator development for SFM calls for diversity in forest production. However, forest exploitation for timber production alone remains the main concern of governments and forest managers. As a result, forest economic efficiency and equity are compromised, as is forest sustainability. Research on using a tenure system for multiple forest product management is on-going.

\section{Specific Distortions - Non - Forestry Sector Policies}

\section{Forest Accessibility: Land Use Policy and Infrastructure}

All analyses of country forestry sector problems include first and foremost land use policy distortions. If a land use policy exists and explicitly protects the forest estate, adequate management capacity is necessary to protect forest boundaries, which are not often recognized as such by migrant populations. More often, existing land use policy is primarily concerned with agricultural use. Governments typically undervalue forestry as a land use and consequently allow the forest estate to accommodate agricultural expansion and thereby ease, for a time, population and poverty pressures.

The lack of an enforced land use policy to protect the forest estate provides institutional accessibility to forests for itinerant farmers and small scale logging operations, both of whom move into the forest once it becomes physically accessible. Various country studies have shown that forest in-migration follows road construction. The consequences of forest accessibility are severe for sustainability because the forest is converted and forestry options are closed.

\section{Agriculture Policies}

Agricultural policies coupled with distorted land use policies have severely compromised the sustainability of forests. Well documented are many cases in South America and Africa where agricultural policies to promote crop or ranch expansion led to conversion of the forest estate. Such policies usually include subsidized inputs, increasing the profitability of agriculture investment. Differential farm land taxes can affect agricultural expansion by prompting farmers to migrate to lower-taxed areas at the forest frontier. Price controls on food crops also prompt expansion as farmers need to bring more land into cultivation in order to survive.
Also well documented are the effects of out-dated land tenurial policies which are frequently remnants of a colonial period. These policies bestow land ownership once a parcel has been "improved". "Improvement" typically involves clearing a certain percentage of it; converting it for agricultural use. In the face of advancing agriculturists, forest dwellers have even been known to clear land in order to obtain official title to it.

\section{Incomplete Information}

In spite of promotional agricultural policies, in many cases, the benefits of forest conversion for agriculture are short-lived because forest soil fertility does not support agricultural use, or appropriate farming practices are unknown. The best use of the land may be forestry, or some combination of forestry, intensive agriculture, and NTFP harvesting. But information is incomplete and the opportunity cost of conversion is unknown. Governments are often unaware of the economic potential of SFM and as a result, land use planning is economically inefficient, and forestry is unsustainable. If governments realize the economic potential of the forest, this information must be communicated to those dwelling on or near forest boundaries. As well, those people need to be capable of benefiting from that information by way of proper property right incentives.

\section{Energy Policies}

Energy policies have been known to affect forest use through a number of avenues. First, fuel is an input into the forestry industry. When it is subsidized, the private cost of deforestation decreases. In Ecuador when fuel prices were subsidized there was an increase in the purchase of chainsaws. Energy policy also affects the forest because wood energy for household use is a substitute for fuel. When fuel is not available to households because of price or infrastructure, the forest will be exploited for fuelwood.

When NTFP property rights are absent, a market failure occurs and fuelwood is often extracted as an open access resource. It does not usually threaten forest sustainability on the forest frontier where it is used for rural households and the forest estate is vast. However, where it is extracted commercially for urban use (regions in Brazil, Somalia and India), it has devastated local woodlots (Mercer and Soussan 1992).

\section{Exchange Rate Policies}

Exchange rate policies affect the domestic currency price of exported products which, in turn, affects production and land use allocation decisions. An undervalued exchange rate means that the price paid for exports - of 
any kind - is high in terms of the domestic currency. The pressure on forestry is two-fold: the availability of greater profits from forest product exports encourages over-cutting; and the greater profitability of export crops prompts forest land conversion for expanded export crop cultivation.

The net effects of an overvalued exchange rate are difficult to gauge. An overvalued exchange rate reduces domestic currency price of exports, which reduces pressure on the exploitation of forests for export production. Generally, production investment shifts from tradables (timber, rattan, etc.) to non-tradables (fuelwood, and locally consumed NTFP). The net effect on the forest depends on the extent to which decreased timber extraction and its associated degradation is replaced by increased NTFP production and its associated environment and equity impacts. However, a currency over-valuation may in fact more severely discourage NTFP production than timber production. Timber production typically realizes substantial excess profit (rents); whereas NTFP production entails large domestic labour costs. The reduced domestic currency price of exported NTFP reduces the margin available to pay for labour. The reduced domestic currency price of exported timber products will reduce an already extraordinarily high rate of return on capital.

Exchange rate overvaluation can also affect the forest by increasing poverty in the agricultural sector. Overvaluation reduces the profitability of agricultural export crops, and as a result may mean that more land is brought under cultivation in order to maintain farm income levels.

\section{Development Policies - Population Relocation}

To relieve population pressures in developed areas, governments have resorted to population resettlement programs which have opened-up undeveloped forest frontier areas. Indonesia's "Transmigration Policy" is a case in point. Primarily due to incomplete information and poor planning, the resettlement policy has had severe consequences for the economic sustainability of the forest estate. In many cases, the settlements were poorly sited: the soils beneath cleared forests were not suitable for agriculture. As a result, fertility declined soon after forest areas were cleared necessitating the clearance of additional forest land to meet agricultural needs. In successful settlements, forests were put under further unplanned pressure because they attracted additional migrants.

\section{Tourism Policy}

Timber harvesting is seldom regarded as a tourist attraction. Domestic and international tourism market opportunities depend upon the ability of the forest estate to support NTFPs such as wildlife for viewing and hunting, and other products for local craft industries. The lack of an enforced tourism/recreation policy forecloses the potential profitability and increased income distribution which would be associated, for example, with the preservation and enhancement of forest amenity value for hiking, or of the management of forest animals for hunting. The result is a sub-optimal mix and use of forest products, the possible exclusion of non-timber product users, and less overall protection for the forest estate. 
Table A.1. Economic Policy Links to Forest Management - Forest Sector Policies

\begin{tabular}{|c|c|c|c|c|c|c|c|c|}
\hline $\begin{array}{l}\text { Specific } \\
\text { Distortion }\end{array}$ & 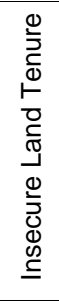 & 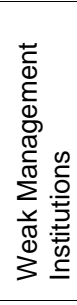 & Linkage & $\begin{array}{l}\text { Effect at Stand } \\
\text { Level }\end{array}$ & 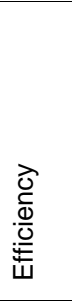 & 昙 & 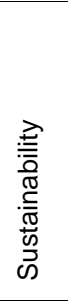 & Examples \\
\hline $\begin{array}{l}\text { Underpriced } \\
\text { Timber }\end{array}$ & $\star$ & $\star$ & $\begin{array}{l}\text { signal of timber } \\
\text { abundance prompts } \\
\text { waste in both } \\
\text { harvesting and } \\
\text { processing practices; } \\
\text { scarcity value (rent) of } \\
\text { the resource captured } \\
\text { by loggers (not forest } \\
\text { owner); excess profits } \\
\text { prompt over-cutting }\end{array}$ & $\begin{array}{l}\text { extraction rate } \\
\text { above social } \\
\text { optimum; extraction } \\
\text { damage in residual } \\
\text { stand; sub-optimal } \\
\text { silviculture; low } \\
\text { recovery rate in } \\
\text { processing }\end{array}$ & $\begin{array}{c}\star \star \\
\star\end{array}$ & $\star \star$ & & $\begin{array}{l}\text { Philippines (Boado } \\
\text { 1988; Cruz et al., } \\
\text { 1997); Indonesia \& } \\
\text { Liberia (Gillis 1988); } \\
\text { Peninsular Malaysia \& } \\
\text { Ghana (Vincent \& } \\
\text { Binkley 1992); Ivory } \\
\text { Coast \& Sarawak } \\
\text { (Repetto 1988); } \\
\text { Cambodia (World Bank } \\
\text { et al. 1996) }\end{array}$ \\
\hline $\begin{array}{l}\text { Insufficient } \\
\text { Price } \\
\text { Differentiation } \\
\text { by Species, } \\
\text { Grade and } \\
\text { Value }\end{array}$ & $\star$ & $\star$ & $\begin{array}{l}\text { stem after-tax values } \\
\text { prompt removal of } \\
\text { only most valuable } \\
\text { stems of primary } \\
\text { species }\end{array}$ & $\begin{array}{l}\text { high-grading; } \\
\text { extensive logging; } \\
\text { extraction damage } \\
\text { and wastage; sub- } \\
\text { optimal silviculture }\end{array}$ & $\begin{array}{c}\star \star \\
\star\end{array}$ & & & $\begin{array}{l}\text { Indonesia \& Liberia } \\
\text { (Gillis 1988); Sabah \& } \\
\text { Ivory Coast (Repetto } \\
\text { 1988); Philippines } \\
\text { (Boado 1988; Cruz et } \\
\text { al., 1997); Ghana } \\
\text { (Vincent \& Binkley } \\
\text { 1992) }\end{array}$ \\
\hline $\begin{array}{l}\text { Harvesting } \\
\text { Rules: } \\
\text { Selective Cut }\end{array}$ & $\star$ & $\star$ & $\begin{array}{l}\text { limited cutting options } \\
\text { prompt removal of } \\
\text { only most valuable } \\
\text { stems and premature } \\
\text { stand reentry for } \\
\text { those stems ineligible } \\
\text { for cutting during first } \\
\text { log over }\end{array}$ & $\begin{array}{l}\text { high-grading; } \\
\text { wastage; severe } \\
\text { extraction damage } \\
\text { due to premature } \\
\text { stand reentry; sub- } \\
\text { optimal silviculture }\end{array}$ & ${ }_{\star}^{\star} \star$ & $\star \star$ & & $\begin{array}{l}\text { Indonesia (Gillis 1988); } \\
\text { Philippines (Boado } \\
\text { 1988); Ghana (Vincent } \\
\text { \& Binkley 1992) }\end{array}$ \\
\hline $\begin{array}{l}\text { Taxation of } \\
\text { Log Exports } \\
\text { (To foster } \\
\text { domestic } \\
\text { processing) }\end{array}$ & $\star$ & $\star$ & $\begin{array}{l}\text { low domestic log input } \\
\text { prices leads to excess } \\
\text { profits prompting } \\
\text { over-investment in } \\
\text { processing; signal of } \\
\text { timber abundance } \\
\text { prompts waste in both } \\
\text { harvesting and } \\
\text { processing }\end{array}$ & $\begin{array}{l}\text { extraction rate } \\
\text { above social } \\
\text { optimum; stand } \\
\text { wastage; excess } \\
\text { processing } \\
\text { capacity and poor } \\
\text { recovery rate in } \\
\text { processing; sub- } \\
\text { optimal silviculture }\end{array}$ & $\begin{array}{c}\star \star \\
\star\end{array}$ & $\star \star$ & & $\begin{array}{l}\text { Indonesia (Gillis 1988); } \\
\text { Peninsular Malaysia } \\
\text { (Vincent \& Binkley } \\
\text { 1992); Ecuador } \\
\text { (Southgate 1992); Ivory } \\
\text { Coast, Ghana \& Brazil } \\
\text { (Repetto 1988) }\end{array}$ \\
\hline $\begin{array}{l}\text { Log Export } \\
\text { Bans (To } \\
\text { foster } \\
\text { domestic } \\
\text { processing) }\end{array}$ & $\star$ & $\star$ & $\begin{array}{l}\text { low domestic log input } \\
\text { prices leads to excess } \\
\text { profits prompting } \\
\text { over-investment in } \\
\text { processing; signal of } \\
\text { timber abundance } \\
\text { prompts waste in both } \\
\text { harvesting and } \\
\text { processing }\end{array}$ & $\begin{array}{l}\text { extraction rate } \\
\text { above social } \\
\text { optimum; stand } \\
\text { wastage; excess } \\
\text { processing } \\
\text { capacity and poor } \\
\text { recovery rate in } \\
\text { processing; sub- } \\
\text { optimal silviculture; } \\
\text { illegal cutting for } \\
\text { export smuggling }\end{array}$ & $\begin{array}{c}\star \star \\
\star\end{array}$ & $\star \star$ & & $\begin{array}{l}\text { Indonesia (Gillis 1988); } \\
\text { Peninsular Malaysia \& } \\
\text { Ghana (Vincent \& } \\
\text { Binkley 1992); Ecuador } \\
\text { (Southgate, 1992); } \\
\text { Philippines \& Ghana } \\
\text { (Repetto 1988); } \\
\text { Cambodia (World Bank } \\
\text { et al. 1996); Thailand } \\
\text { (Sadoff 1993) }\end{array}$ \\
\hline $\begin{array}{l}\text { Vertical } \\
\text { Integration of } \\
\text { Forestry } \\
\text { Industry }\end{array}$ & $\star$ & $\star$ & $\begin{array}{l}\text { excess profits prompt } \\
\text { inefficient processing; } \\
\text { timber supply needs } \\
\text { of industry prompt } \\
\text { narrow management } \\
\text { goals }\end{array}$ & $\begin{array}{l}\text { timber wastage; } \\
\text { sub-optimal } \\
\text { silviculture; sub- } \\
\text { optimal use and } \\
\text { damage to NTFPs }\end{array}$ & $\begin{array}{c}\star \star \\
\star\end{array}$ & $\star$ & $\star \star$ & $\begin{array}{l}\text { Philippines, Brazil \& } \\
\text { Ivory Coast (Repetto } \\
\text { 1988); Ghana, } \\
\text { Indonesia \& Malaysia } \\
\text { (Gillis 1988) }\end{array}$ \\
\hline $\begin{array}{l}\text { Lack of } \\
\text { Property } \\
\text { Rights on } \\
\text { NTFPs - } \\
\text { Market Failure }\end{array}$ & $\star$ & $\star$ & $\begin{array}{l}\text { emphasis on timber } \\
\text { only prompts neglect } \\
\text { and degradation of } \\
\text { non-timber resources }\end{array}$ & $\begin{array}{l}\text { sub-optimal use } \\
\text { and damage to } \\
\text { NTFPs; possible } \\
\text { exclusion of NTFP } \\
\text { users; reduced } \\
\text { forest protection }\end{array}$ & $\star \star$ & $\star \star$ & ${ }_{\star} \star$ & $\begin{array}{l}\text { Sri Lanka } \\
\text { (Bogahawatte 1997); } \\
\text { Costa Rica (Persson \& } \\
\text { Munasinghe 1997); } \\
\text { Indonesia, Sabah \& } \\
\text { Sarawak (Repetto } \\
\text { 1988); Ghana (Gillis } \\
\text { 1988) }\end{array}$ \\
\hline
\end{tabular}


Table A.2. Economic Policy Links to Forest Management - Non-Forest Sector Policies

\begin{tabular}{|c|c|c|c|c|c|c|c|c|}
\hline $\begin{array}{l}\text { Specific } \\
\text { Distortion }\end{array}$ & 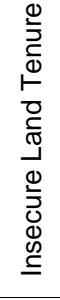 & 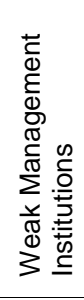 & Linkage & $\begin{array}{l}\text { Effect at Stand } \\
\text { Level }\end{array}$ & 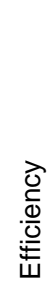 & 壱 & 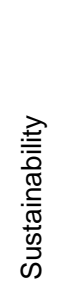 & Examples \\
\hline $\begin{array}{l}\text { Lack of } \\
\text { Enforced } \\
\text { Land Use } \\
\text { Policy }\end{array}$ & $\star$ & $\star$ & $\begin{array}{l}\text { institutional } \\
\text { accessibility prompts } \\
\text { the in-migration of } \\
\text { itinerant farmers and } \\
\text { small-scale timber } \\
\text { operators }\end{array}$ & $\begin{array}{l}\text { forest conversion } \\
\text { due to in-migration; } \\
\text { use of forest } \\
\text { products lost to } \\
\text { traditional users; } \\
\text { stand damage by } \\
\text { premature re- } \\
\text { logging }\end{array}$ & $\star$ & $\star \star$ & ${ }_{\star}^{\star}$ & $\begin{array}{l}\text { Philippines (Cruz et } \\
\text { al. 1997); Brazil \& } \\
\text { Ecuador (Southgate } \\
\text { 1992); Costa Rica } \\
\text { (Persson \& } \\
\text { Munasinghe 1997); } \\
\text { Thailand (Sadoff } \\
\text { 1993) }\end{array}$ \\
\hline $\begin{array}{l}\text { Infrastructure } \\
\text { Development } \\
\text { in Forest } \\
\text { Areas }\end{array}$ & $\star$ & $\star$ & $\begin{array}{l}\text { physical accessibility } \\
\text { prompts in-migration of } \\
\text { itinerant farmers and } \\
\text { small scale timber } \\
\text { operators }\end{array}$ & $\begin{array}{l}\text { forest conversion } \\
\text { due to in-migration; } \\
\text { loss of all forest } \\
\text { products; stand } \\
\text { damage due to } \\
\text { premature logging } \\
\text { re-entry }\end{array}$ & $\star$ & $\star$ & ${ }_{\star}^{\star \star}$ & $\begin{array}{l}\text { Philippines (Cruz et } \\
\text { al. 1997); Brazil \& } \\
\text { Ecuador (Southgate, } \\
\text { 1992); Liberia, Ivory } \\
\text { Coast, Ghana, } \\
\text { Sabah, Sarawak \& } \\
\text { Indonesia (Gillis } \\
\text { 1988); Sri Lanka } \\
\text { (Bogahawatte 1997); } \\
\text { Thailand (Sadoff } \\
\text { 1993); Brazil } \\
\text { (Andersen 1997) }\end{array}$ \\
\hline $\begin{array}{l}\text { Agricultural } \\
\text { Incentives } \\
\text { (For Export } \\
\text { Crop } \\
\text { Promotion or } \\
\text { Domestic } \\
\text { Food Supply) }\end{array}$ & & $\star$ & $\begin{array}{l}\text { profitability of ranching, } \\
\text { tree crops, agricultural } \\
\text { crops, or fish ponds } \\
\text { prompts expanded } \\
\text { production in forest } \\
\text { frontier }\end{array}$ & $\begin{array}{l}\text { forest conversion } \\
\text { due to in-migration; } \\
\text { loss of all forest } \\
\text { products }\end{array}$ & $\star$ & $\star \star$ & ${ }_{\star}^{\star} \star$ & $\begin{array}{l}\text { Brazil (Southgate } \\
\text { 1992); Costa Rica } \\
\text { (Persson \& } \\
\text { Munasinghe 1997); } \\
\text { Liberia, Ghana, Ivory } \\
\text { Coast \& Peninsular } \\
\text { Malaysia (Gillis } \\
\text { 1988) }\end{array}$ \\
\hline $\begin{array}{l}\text { Agriculture } \\
\text { Land Tenurial } \\
\text { Policy }\end{array}$ & & $\star$ & $\begin{array}{l}\text { "improvement" for } \\
\text { formal land tenure } \\
\text { prompts forest } \\
\text { clearance }\end{array}$ & $\begin{array}{l}\text { forest conversion } \\
\text { by migrant farmers } \\
\text { and forest dwellers }\end{array}$ & $\star$ & $\star \star$ & ${ }_{\star}^{\star} \star$ & $\begin{array}{l}\text { Ivory Coast (Gillis } \\
\text { 1988); Brazil \& } \\
\text { Ecuador (Southgate, } \\
\text { 1992); Costa Rica } \\
\text { (Persson \& } \\
\text { Munasinghe, 1997); } \\
\text { Sabah (Repetto } \\
\text { 1988) }\end{array}$ \\
\hline $\begin{array}{l}\text { Agricultural } \\
\text { Price Controls }\end{array}$ & & & $\begin{array}{l}\text { low prices on food } \\
\text { crops prompt } \\
\text { expanded cultivation }\end{array}$ & $\begin{array}{l}\text { forest conversion } \\
\text { by farmers }\end{array}$ & $\star$ & $\star \star$ & ${ }_{\star}^{\star}$ & Ghana (Gillis 1988) \\
\hline $\begin{array}{l}\text { Incomplete } \\
\text { Information }\end{array}$ & $\star$ & $\star$ & $\begin{array}{l}\text { opportunity cost of } \\
\text { forest clearance } \\
\text { unknown to migrant } \\
\text { farmers; or, suitable } \\
\text { cropping patterns } \\
\text { unknown, prompting } \\
\text { further clearance }\end{array}$ & $\begin{array}{l}\text { forest conversion } \\
\text { by migrants }\end{array}$ & $\star$ & $\star \star$ & ${ }_{\star}^{\star \star}$ & $\begin{array}{l}\text { Brazil \& Ecuador } \\
\text { (Southgate 1992); } \\
\text { Brazil (Andersen et } \\
\text { al. 1996) }\end{array}$ \\
\hline $\begin{array}{l}\text { Subsidized } \\
\text { Fuel Oil }\end{array}$ & $\star$ & & $\begin{array}{l}\text { cheap fuel reduces } \\
\text { cost of deforestation } \\
\text { (chainsaws cheaper to } \\
\text { operate) }\end{array}$ & $\begin{array}{l}\text { forest conversion } \\
\text { by farmers; low } \\
\text { recovery rate from } \\
\text { "on-site" } \\
\text { processing }\end{array}$ & $\star$ & & ${ }_{\star}^{\star \star}$ & $\begin{array}{l}\text { Ecuador (Southgate } \\
\text { 1992); Kellenberg } \\
\text { 1995) }\end{array}$ \\
\hline $\begin{array}{l}\text { Unaddressed } \\
\text { Fuelwood } \\
\text { Market Failure }\end{array}$ & $\star$ & $\star$ & $\begin{array}{l}\text { open-access and zero- } \\
\text { priced fuelwood and/or } \\
\text { lack of energy options } \\
\text { prompts deforestation } \\
\text { to meet both urban and } \\
\text { rural energy needs }\end{array}$ & $\begin{array}{l}\text { deforestation for } \\
\text { fuelwood }\end{array}$ & $\star$ & & ${ }_{\star}^{\star}$ & $\begin{array}{l}\text { Ghana \& Indonesia } \\
\text { (Gillis, 1988); } \\
\text { various regions } \\
\text { (Mercer \& Soussan, } \\
\text { 1992); Sri Lanka } \\
\text { (Bogahawatte 1997) }\end{array}$ \\
\hline
\end{tabular}


Table A.2. (con'd) Economic Policy Links to Forest Management - Non-Forest Sector Policies

\begin{tabular}{|c|c|c|c|c|c|c|c|c|}
\hline $\begin{array}{l}\text { Specific } \\
\text { Distortion }\end{array}$ & 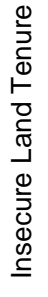 & 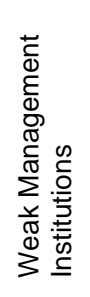 & Linkage & Effect at Stand Level & 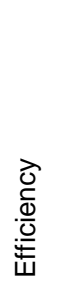 & 壱 & 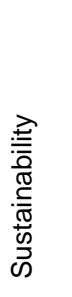 & Examples \\
\hline $\begin{array}{l}\text { Overvalued } \\
\text { Exchange } \\
\text { Rate }\end{array}$ & & $\star$ & $\begin{array}{l}\text { low domestic currency } \\
\text { export prices affect: } 1 \text { ) } \\
\text { the relative profitability } \\
\text { of timber and non- } \\
\text { timber products; and 2) } \\
\text { farmers receive less for } \\
\text { agricultural exports }\end{array}$ & $\begin{array}{l}\text { reduction in } \\
\text { production of non- } \\
\text { wood products } \\
\text { (Indonesia); illegal } \\
\text { cutting for export } \\
\text { (Ghana); forest } \\
\text { conversion for } \\
\text { expanded agriculture } \\
\text { (Philippines) }\end{array}$ & $\star$ & $\star \star$ & $\star \star \star$ & $\begin{array}{l}\text { Ghana (Gillis 1988); } \\
\text { Indonesia (Gillis } \\
\text { 1988); Philippines } \\
\text { (Cruz et al. 1997) }\end{array}$ \\
\hline $\begin{array}{l}\text { Undervalued } \\
\text { Exchange } \\
\text { Rate }\end{array}$ & & $\star$ & $\begin{array}{l}\text { high domestic currency } \\
\text { export prices prompts } \\
\text { overcutting by loggers } \\
\text { and expansion of } \\
\text { export crops }\end{array}$ & $\begin{array}{l}\text { excessive timber } \\
\text { extraction; forest } \\
\text { conversion for export } \\
\text { crops }\end{array}$ & $\star$ & $\star \star$ & 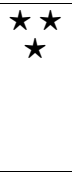 & $\begin{array}{l}\text { Malaysia (Gillis } \\
\text { 1988) }\end{array}$ \\
\hline $\begin{array}{l}\text { Population } \\
\text { Relocation } \\
\text { Policy }\end{array}$ & & $\star$ & $\begin{array}{l}\text { soil fertility quickly } \\
\text { declines in poorly sited } \\
\text { settlements prompting } \\
\text { settlers to clear } \\
\text { additional acreage in } \\
\text { forest frontier }\end{array}$ & $\begin{array}{l}\text { forest conversion by } \\
\text { resettled population } \\
\text { and other migrants to } \\
\text { resettled area }\end{array}$ & $\star$ & $\star \star$ & $\star \star \star$ & $\begin{array}{l}\text { Indonesia (Repetto } \\
\text { 1988) }\end{array}$ \\
\hline $\begin{array}{l}\text { Lack of } \\
\text { Recreation } \\
\text { Policy }\end{array}$ & & $\star$ & $\begin{array}{l}\text { reduced profitability of } \\
\text { NTFP development } \\
\text { prompts forest use for } \\
\text { timber extraction only }\end{array}$ & $\begin{array}{l}\text { sub-optimal use of } \\
\text { and damage to } \\
\text { NTFP; exclusion of } \\
\text { NTFP users; reduced } \\
\text { forest protection }\end{array}$ & 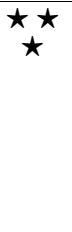 & $\star \star$ & $\star \star$ & $\begin{array}{l}\text { Kenya (1997) } \\
\text { commenced co- } \\
\text { Tourism/ } \\
\text { management of } \\
\text { forestry, wildlife \& } \\
\text { parks estate; Turkey } \\
\text { (Bann 1998) }\end{array}$ \\
\hline
\end{tabular}




\section{Review of Economic Criteria \& Indicators}

\section{Representative Criteria \& Indicators}

Tables B.1 to B.7 provide examples of criteria and indicators used to gauge the economic dimension of SFM. Representative economic indicators were described by: (i) their ability to say something about the goals of economic efficiency, equity, and sustainability; (ii) their relevance to different points of intervention (stand management, institutional, and policy levels); and (iii) their administrative applicability (national, regional, local) according to the developer.

Few of the indicators pertain to the environmental impacts of logging on the stand. Despite the multitude of these indicators, and their implications for economic efficiency (in terms of stand productivity maintenance), they are not usually considered part of the economic dimension of SFM.

The C\&I were drawn from the sets of seven organizations involved in the promotion of sustainable forest management (SFM). Three of the organizations are developers of "general guidelines" for SFM: the International Tropical Timber Organization, the African Timber Organization, and the Amazon Cooperation Treaty signatories. The other four organizations Initiative Tropenwald, the Soil Association (Woodmark), Rainforest Alliance (SmartWood), and Lembaga Ekolabel Indonesia - are certification bodies that currently undertake or intend to undertake evaluation/certification of sustainable forest management.

\section{International Tropical Timber Organization}

ITTO's C\&I form the basis on which most other standards for SFM have been and are being developed; they are not meant to be operationalized. The set includes C\&I for both the national and local (FMU) levels, but most of the indicators are relevant to both levels. Under "Legal Framework", the ITTO set includes only one economic policy indicator which is a yes/no question as to the existence of a forest policy "ensuring a balanced use of the forest resources of the country." The "Economic Framework" indicators are essentially indicators of institutional capacity. The set covers forest security, ecosystem condition and biological diversity, production and environmental impact management, and community participation. The category of "Economic Effects" includes: total investment and employment indicators; timber and NTFP production; and one indicator of "efficiency of utilization".

Most of the indicators would require quantitative answers, some would require yes/no responses, and a few would involve qualitative explanation. Also, in contrast to the indicator sets of the certification bodies (described below), a number of ITTO's indicators require data to be expressed in a time series. "Total investment", for example, is to be expressed in a time series.

\section{African Timber Organization}

The ATO has drafted a set of C\&I in response to its members' declining production levels and international market shares. The C\&I set is not detailed and is composed of (indicator) statements that would be assessed by a yes/no response or an agreement ranking. The economic dimension is addressed only in a requirement that the management plan include an "economic and financial evaluation". Although not individually specified, some of the indicators are clearly national in nature while others apply to the FMU. Interestingly, the first principle of the set states that: "Sustainability of the forest and its multiple functions is a high political priority."

\section{The Tarapoto Proposal}

The Tarapoto Proposal C\&I set is being developed by the members of the Amazon Cooperation Treaty. The set is large, containing both national and local levels, as well as a few for the global level. It is not operational. In contrast to the other sets examined here, this set includes more indicators of the socio-economic dimension, than of the legal and institutional capacity 
dimensions. There is a sizable number of indicators to capture the economic dimension of forestry, at both the national and local levels. For example, the "efficiency and competitiveness" of production and processing systems is a national level indicator; as is the "economic profitability" of the forest use. Investment and rates of return are also national level indicators. Economic policies are mentioned only in terms of zoning.

\section{Initiative Tropenwald}

ITW developed a very detailed set of C\&I. It contains C\&I for three administrative levels: national, regional and local. All C\&I are couched in terms either of the institutional framework of the forestry sector (at the national level); or of the management capability and capacity of the forestry service (at the regional and local levels). The indicators for each criterion are evaluated on a yes/no basis where "yes" implies agreement with the (indicator) statement. A category "other" is allowed for qualifying notes.

At the national level, policy issues are addressed very briefly in terms of whether a land use policy and a forest policy exists. Substantial coverage is given to the legal framework within which forestry operates, and the extent to which forestry research is undertaken. An explicit "economic" dimension is not included at any indicator level, but at the national and regional levels there is a large number of indicators of research into economic issues - product development, processing, profitability evaluation, marketing, etc.

At the regional level, emphasis is on the rights of local people and the legal and administrative capacity of regional authorities to gather basic data, conduct research and control activities affecting the regional forest (boundary control, infrastructure development). The local level criteria revolve around the quality of planning for timber production (availability of data, staff training, recognizable methods); and the management capacity to implement a plan that controls for the environmental impacts of logging.

\section{Woodmark and SmartWood}

The C\&I of Woodmark and SmartWood have both been developed for application at the local level. As such, neither addresses the national policy issues that would affect the forestry environment. Both have criteria to judge local management capabilities but Woodmark is by far the more detailed in its requirements of the "management plan." Woodmark emphasizes the application of the "precautionary principle" in the management approach. Woodmark's certification program is for application to UK forests; SmartWood proposes the adaptation of its set to various forest regions of the world. The Woodmark indicators are to be assessed qualitatively; SmartWood has a ranking system wherein the assessor ranks the (indicator) statement on a scale ranging between "favourable" and "unfavourable".

As with ITW, the Woodmark and SmartWood sets contain criteria to judge environmental impacts, sustainable yield, property rights, community benefits; but, as is not the case with ITW, they also include an explicit "economic" dimension. Criteria exist in both for judging whether the economic potential of the (local) forest is being realized (NTFPs and secondary species). SmartWood also has a category "Economic Viability" with three criteria which judge the ability of stumpage rates and rent to encourage SFM. Regarding equity, both of these sets contain indicators of the right of workers to unionize and to negotiate working conditions. Woodmark also contains a large number of C\&I to judge the efficiency of timber processing.

\section{Lembaga Ekolabel Indonesia}

The LEI C\&I have been developed to evaluate the FMU. Its first criterion captures one of the main difficulties in SFM: the security and certainty of the forest estate from the viewpoint of both the community and the forest manager. LEI directly addresses issues of efficiency. "Efficiency in exploiting the forest" involves efficiency in wood exploitation, the production of NTFP, and the minimization of negative environmental and social impacts. LEI also addresses "Business Profitability" which includes criteria for long-term certainty of investment.

Many of the LEI indicators are quantitative indicators - ratios, frequencies, numbers of this or that. This is in contrast to those from a number of the other C\&I initiatives that rely heavily on "statements" to be verified with a simple yes/no, ranked on a scale of agreement, or answered prosaically. 
Table B.1. Economic Dimensions of C\&I Set - ITTO

\begin{tabular}{|c|c|c|c|c|c|c|c|c|}
\hline \multirow[b]{2}{*}{ Source } & \multirow[b]{2}{*}{ Criterion or Indicator } & \multicolumn{3}{|c|}{ Goal } & \multicolumn{3}{|c|}{$\begin{array}{l}\text { Intervention } \\
\text { Point }\end{array}$} & \multirow{2}{*}{ 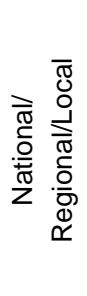 } \\
\hline & & 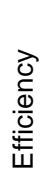 & 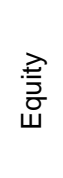 & 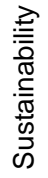 & 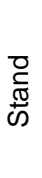 & 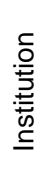 & $\frac{\grave{0}}{\circ}$ & \\
\hline ITTO 1.3 & $\begin{array}{l}\text { Availability of financial resources (budget) for necessary } \\
\text { expenditure, and for investment and reinvestment in forest } \\
\text { management, administration, research and human resource } \\
\text { development from [various sources]. }\end{array}$ & & & $\star$ & $\star$ & $\star$ & & $\mathrm{N}, \mathrm{L}$ \\
\hline ITTO 1.4 & $\begin{array}{l}\text { Adequate institutional structure to support sustainable forest } \\
\text { management. }\end{array}$ & & & $\star$ & $\star$ & $\star$ & & $N, L$ \\
\hline ITTO 1.5 & $\begin{array}{l}\text { Number and adequacy of trained professional and technical } \\
\text { personal at all levels to perform the necessary tasks to ensure } \\
\text { sustainable forest management. }\end{array}$ & & & $\star$ & $\star$ & $\star$ & & $N, L$ \\
\hline ITTO 1.6 & $\begin{array}{l}\text { Number of professional personnel to support the various } \\
\text { aspects of sustainable forest management: research and } \\
\text { extension. }\end{array}$ & & & $\star$ & $\star$ & $\star$ & & $N, L$ \\
\hline ITTO 1.7 & $\begin{array}{l}\text { Existence of adequate technology to practice sustainable } \\
\text { forest management and the efficient conversion of forest } \\
\text { produce }\end{array}$ & & & $\star$ & $\star$ & $\star$ & & $N, L$ \\
\hline ITTO 1.8 & $\begin{array}{l}\text { Existence of internal checking mechanisms and capacity for } \\
\text { periodical monitoring, evaluation and feed-back on progress } \\
\text { towards sustainable forest management. }\end{array}$ & & & $\star$ & $\star$ & $\star$ & & $N, L$ \\
\hline ITTO 1.9 & $\begin{array}{l}\text { Degree of public participation at various levels of forest } \\
\text { management, such as planning, decision making and } \\
\text { monitoring of progress towards sustainable forest } \\
\text { management. }\end{array}$ & & & $\star$ & $\star$ & $\star$ & & $N, L$ \\
\hline ITTO 1.10 & $\begin{array}{l}\text { Adequate and timely information to increase public awareness } \\
\text { about forest policies, legislation an sustainable forest } \\
\text { practices. }\end{array}$ & & & $\star$ & $\star$ & $\star$ & & $\mathrm{N}, \mathrm{L}$ \\
\hline ITTO 2.1 & $\begin{array}{l}\text { Extent and percentage of total area, and expressed as a time } \\
\text { series, under: natural forest, plantation forest, and permanent } \\
\text { forest estate secured by legislation. }\end{array}$ & & & $\star$ & $\star$ & $\star$ & & $\mathrm{N}, \mathrm{L}$ \\
\hline ITTO 2.2 & $\begin{array}{l}\text { Extent and percentage of external boundaries of the } \\
\text { permanent forest estate demarcated or clearly defined. }\end{array}$ & & & $\star$ & $\star$ & $\star$ & & $N, L$ \\
\hline ITTO 2.3 & $\begin{array}{l}\text { The extent and nature of: illegal exploitation, encroachment, } \\
\text { re-entry, slash and burn, illegal hunting, etc. }\end{array}$ & & & $\star$ & $\star$ & $\star$ & & $\mathrm{N}, \mathrm{L}$ \\
\hline ITTO 7.1 & $\begin{array}{l}\text { Total investment in the forestry and related sectors, and } \\
\text { expressed in time series. }\end{array}$ & & & $\star$ & $\star$ & $\star$ & & $N, L$ \\
\hline ITTO 7.2 & $\begin{array}{l}\text { Amount of direct and indirect employment in the forestry and } \\
\text { related sectors as percentages of total employment, and } \\
\text { expressed in a time series. }\end{array}$ & & $\star$ & & $\star$ & & & $\mathrm{N}, \mathrm{L}$ \\
\hline ITTO 7.3 & $\begin{array}{l}\text { Volume and value of wood and non-wood products traded in: } \\
\text { a) domestic markets, and b) international market; expressed } \\
\text { in time series. }\end{array}$ & $\star$ & & & $\star$ & & & $N, L$ \\
\hline ITTO 7.4 & $\begin{array}{l}\text { Volume and value of wood and non-wood forest products, } \\
\text { including fuelwood for subsistence use. }\end{array}$ & $\star$ & & & $\star$ & & & $N, L$ \\
\hline ITTO 7.5 & $\begin{array}{l}\text { Existence of mechanism for the efficient distribution of } \\
\text { incentive and the fair and equitable sharing of costs and } \\
\text { benefits by the parties involved. }\end{array}$ & & $\star$ & & $\star$ & $\star$ & & $N, L$ \\
\hline ITTO 7.7 & $\begin{array}{l}\text { Efficiency of utilization: a) percentage of utilisable volume left } \\
\text { in the forest harvesting, and b) recovery rates of wood } \\
\text { processing mills. }\end{array}$ & $\star$ & & & $\star$ & & $\star$ & $\mathrm{N}, \mathrm{L}$ \\
\hline ITTO 7.9 & $\begin{array}{l}\text { Number of people dependent on forests for traditional and } \\
\text { customary lifestyles. }\end{array}$ & & $\star$ & & $\star$ & & & $\mathrm{N}, \mathrm{L}$ \\
\hline ITTO 7.10 & $\begin{array}{l}\text { Number of forest recreation sites established and available for } \\
\text { use by the general public and the number of visitors to these } \\
\text { sites. }\end{array}$ & $\star$ & & $\star$ & $\star$ & $\star$ & & $\mathrm{N}, \mathrm{L}$ \\
\hline ITTO 7.12 & $\begin{array}{l}\text { Areas of forest fruit trees and other tree species managed for } \\
\text { direct use and benefit of local communities, an expressed in a } \\
\text { time series. }\end{array}$ & & $\star$ & $\star$ & $\star$ & & & $N, L$ \\
\hline
\end{tabular}


Table B.2. Economic Dimensions of C\&I Set - African Timber Organization

\begin{tabular}{|c|c|c|c|c|c|c|c|c|}
\hline \multirow[b]{2}{*}{ Source } & \multirow[b]{2}{*}{ Criterion or Indicator } & \multicolumn{3}{|c|}{ Goal } & \multicolumn{3}{|c|}{$\begin{array}{l}\text { Intervention } \\
\text { Point }\end{array}$} & \multirow{2}{*}{ 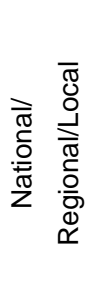 } \\
\hline & & 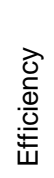 & 蒿 & 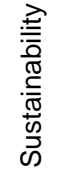 & 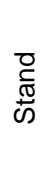 & 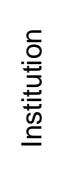 & 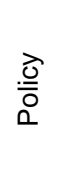 & \\
\hline ATO 0.1 & $\begin{array}{l}\text { The Government has clear forest development objectives and } \\
\text { a realistic plan to meet them. }\end{array}$ & & & $\star$ & & $\star$ & & $N$ \\
\hline ATO 0.2 & $\begin{array}{l}\text { The Government allocates adequate means for sustainable } \\
\text { management of forests. }\end{array}$ & & & $\star$ & & $\star$ & & $\mathrm{N}$ \\
\hline АТО 0.3 & $\begin{array}{l}\text { Actions are taken by the Government to reduce all types of } \\
\text { pressure on the forest. }\end{array}$ & & & $\star$ & $\star$ & $\star$ & & $\mathrm{N}$ \\
\hline ATO I.1 & $\begin{array}{l}\text { Areas devoted to forestry activities or the permanent forest } \\
\text { estate are clearly delimited and their boundaries have been } \\
\text { well established. }\end{array}$ & & & $\star$ & $\star$ & $\star$ & & $\mathrm{N}$ \\
\hline ATO I.2.3 & $\begin{array}{l}\text { There is collaboration between the forestry service, } \\
\text { agricultural service, public order authorities and other public } \\
\text { services concerned in forest management. }\end{array}$ & & & $\star$ & & $\star$ & & $\mathrm{N}$ \\
\hline ATO I.3.1 & $\begin{array}{l}\text { There is a direct, sustainable, efficient system to interest } \\
\text { various stakeholders in protecting the forest against clearing, } \\
\text { fires and poaching. }\end{array}$ & & & $\star$ & $\star$ & $\star$ & & $\mathrm{N}, \mathrm{L}$ \\
\hline ATO II.1 & $\begin{array}{l}\text { A management plan has been established for the sustainable } \\
\text { management of the forest taking into account all its } \\
\text { components and functions such as timber production, other } \\
\text { forest products, contribution to the well-being of the local } \\
\text { people, ecology. }\end{array}$ & & & $\star$ & $\star$ & $\star$ & & L \\
\hline ATO II.1.3 & Management is effectively implemented. & & & $\star$ & $\star$ & $\star$ & & $\mathrm{L}$ \\
\hline ATO II.2 & $\begin{array}{l}\text { Forestry service and other stakeholders of the sector have } \\
\text { enough capacity to properly develop and manage the forest } \\
\text { for all its roles (timber production, other forest products, } \\
\text { ecology, farmer-forest relationship. }\end{array}$ & & & $\star$ & $\star$ & $\star$ & & $\mathrm{N}, \mathrm{L}$ \\
\hline ATO IIA. 1 & $\begin{array}{l}\text { Standards for silvicultural and other activities, adapted to the } \\
\text { specific ecology of the forest and ensuring sustainable } \\
\text { management, have been developed and are operational. }\end{array}$ & $\star$ & & $\star$ & $\star$ & $\star$ & & L \\
\hline ATO IIA.1.3 & $\begin{array}{l}\text { In the area of harvesting, the standards are explicit on (inter } \\
\text { alia) the maximum number of tress to be harvested }\end{array}$ & $\star$ & & & $\star$ & $\star$ & & L \\
\hline ATO IIA.2.3 & $\begin{array}{l}\text { Calculations of allowable cut and rotation period are clearly } \\
\text { detailed in the management plan ... and considered } \\
\text { compatible with sustainable production of the forest. }\end{array}$ & $\star$ & & & $\star$ & $\star$ & & L \\
\hline ATO IIA.2.9 & $\begin{array}{l}\text { The application of provisions of the contract agreement is to } \\
\text { be assessed periodically. Non-compliance is penalized. }\end{array}$ & & & $\star$ & $\star$ & $\star$ & & $\mathrm{N}, \mathrm{L}$ \\
\hline ATO IIB.4 & $\begin{array}{l}\text { Guidelines for harvesting of non-timber forest products are } \\
\text { monitored, evaluated and can be corrected if necessary. }\end{array}$ & $\star$ & & $\star$ & $\star$ & $\star$ & & $\mathrm{N}, \mathrm{L}$ \\
\hline ATO IV.1 & $\begin{array}{l}\text { All stakeholders have their user or property rights well defined } \\
\text { and secure. }\end{array}$ & $\star$ & $\star$ & $\star$ & $\star$ & $\star$ & & $\mathrm{N}, \mathrm{L}$ \\
\hline ATO IV.2 & All stakeholders participate in forest resources & & $\star$ & $\star$ & $\star$ & $\star$ & & $\mathrm{N}, \mathrm{L}$ \\
\hline ATO IV.5.2 & Wages and other benefits conform to national standards. & & $\star$ & & $\star$ & & & $\mathrm{N}, \mathrm{L}$ \\
\hline ATO IV.5.3 & $\begin{array}{l}\text { Forest-dependent people have opportunity to be employed } \\
\text { and trained by forest companies. }\end{array}$ & & $\star$ & & $\star$ & & & L \\
\hline
\end{tabular}


Table B.3. Economic Dimensions of C\&I Set - Tarapoto Proposal

\begin{tabular}{|c|c|c|c|c|c|c|c|c|}
\hline \multirow[b]{2}{*}{ Source } & \multirow[b]{2}{*}{ Criterion or Indicator } & \multicolumn{3}{|c|}{ Goal } & \multicolumn{3}{|c|}{$\begin{array}{l}\text { Intervention } \\
\text { Point }\end{array}$} & \multirow{2}{*}{ 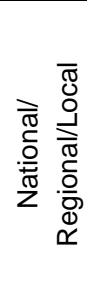 } \\
\hline & & 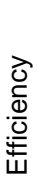 & $\underset{⿱ 亠 䒑}{\stackrel{7}{W}}$ & 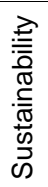 & $\frac{0}{\frac{0}{\pi}}$ & 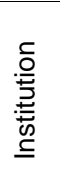 & $\frac{\bar{o}}{\overline{0}}$ & \\
\hline TP 8.c & $\begin{array}{l}\text { Legal framework which guarantees the stability of forest } \\
\text { investments in the long term. }\end{array}$ & & & $\star$ & $\star$ & $\star$ & & $\mathrm{L}$ \\
\hline TP 9.a & $\begin{array}{l}\text { Annual extraction of timber and non-timber forest products } \\
\text { compatible with the sustainable capacity of the resource base. }\end{array}$ & $\star$ & & $\star$ & $\star$ & & & $\mathrm{L}$ \\
\hline TP 9.b & $\begin{array}{l}\text { Area and percentage of forest soils affected by significant } \\
\text { alterations in physical-chemical properties and erosion. }\end{array}$ & $\star$ & & $\star$ & $\star$ & & & $\mathrm{L}$ \\
\hline TP 9.c & Effectiveness of systems of administration and control. & & & $\star$ & & $\star$ & & L \\
\hline TP 9.d & Degree of diversification of production. & $\star$ & & $\star$ & $\star$ & & & $\mathrm{L}$ \\
\hline TP 9.e & Degree of utilization of environmentally friendly technologies. & $\star$ & & & $\star$ & & & $\mathrm{L}$ \\
\hline TP 11.a & Quality of life of local populations. & & $\star$ & $\star$ & $\star$ & & & $\mathrm{L}$ \\
\hline TP 11.b & Profitability and rates of return of forest management. & $\star$ & & & $\star$ & & & $\mathrm{L}$ \\
\hline TP 11.c & $\begin{array}{l}\text { Efficiency of the systems for the production and processing of } \\
\text { forest products. }\end{array}$ & $\star$ & & & $\star$ & & $\star$ & $\mathrm{L}$ \\
\hline TP 11.d & $\begin{array}{l}\text { Impact of the economic exploitation of forests on the } \\
\text { availability of forest resources of importance to local } \\
\text { populations. }\end{array}$ & & $\star$ & & $\star$ & & & $\mathrm{L}$ \\
\hline TP 11.e & Number of direct and indirect jobs and level of income. & & $\star$ & & $\star$ & & & $\mathrm{L}$ \\
\hline TP 11.f & $\begin{array}{l}\text { Nature and quantity of forest benefits derived from forest } \\
\text { management }\end{array}$ & $\star$ & & $\star$ & $\star$ & & & $\mathrm{L}$ \\
\hline TP 11.g & Annual quantity of products extracted per ha. & $\star$ & & $\star$ & $\star$ & & & $\mathrm{L}$ \\
\hline TP 11.h & Aggregate value of production. & $\star$ & & & $\star$ & & & $\mathrm{L}$ \\
\hline TP 11.i & $\begin{array}{l}\text { Mechanisms for the consultation and effective participation of } \\
\text { local communities in the management of forest resources } \\
\text { depending on the scale of management. }\end{array}$ & & $\star$ & $\star$ & $\star$ & $\star$ & & $\mathrm{L}$ \\
\hline
\end{tabular}


Table B.4. Economic Dimensions of C\&I Set - Iniative Tropenwald

\begin{tabular}{|c|c|c|c|c|c|c|c|c|}
\hline \multirow[b]{2}{*}{ Source } & \multirow[b]{2}{*}{ Criterion or Indicator } & \multicolumn{3}{|c|}{ Goal } & \multicolumn{3}{|c|}{$\begin{array}{l}\text { Intervention } \\
\text { Point }\end{array}$} & \multirow{2}{*}{ 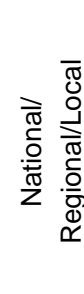 } \\
\hline & & 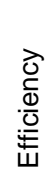 & 売 & 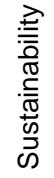 & 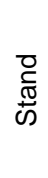 & 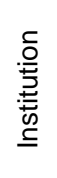 & $\frac{\grave{O}}{0}$ & \\
\hline ITW A.1.1 & $\begin{array}{l}\text { A legally enforceable land use plan exits which includes } \\
\text { decisions about the size and location of the permanent } \\
\text { forest estate, divided into permanent protection and } \\
\text { production areas, and other forest areas. }\end{array}$ & & & $\star$ & $\star$ & $\star$ & $\star$ & $\mathrm{N}$ \\
\hline ITW A.1.2 & $\begin{array}{l}\text { A legally gazetted forest policy defines the nationally } \\
\text { accepted values of the forest and their functions within } \\
\text { the framework of national development policy. }\end{array}$ & & & $\star$ & $\star$ & $\star$ & $\star$ & $\mathrm{N}$ \\
\hline ITW A.1.3 & $\begin{array}{l}\text { A forest law exists which is in harmony with the goal of } \\
\text { sustainable forest management. }\end{array}$ & & & $\star$ & $\star$ & $\star$ & & $\mathrm{N}$ \\
\hline ITW A.3.1.1 & $\begin{array}{l}\text { Laws directly linked to forest management [include]: } \\
2.1 \text { definition of different kinds of statutory forest } \\
\text { ownership. }\end{array}$ & $\star$ & $\star$ & $\star$ & $\star$ & $\star$ & & $\mathrm{N}$ \\
\hline ITW A.3.1.1 & $\begin{array}{l}\text { Laws directly linked to forest management [include]: } \\
2.5 \text { allocation of rights to use the forest. }\end{array}$ & $\star$ & $\star$ & $\star$ & $\star$ & $\star$ & & $\mathrm{N}$ \\
\hline ITW A.3.1.2 & $\begin{array}{l}\text { Laws indirectly linked to forest management [include]: } \\
1.1 \text { accident compensation; } 1.3 \text { provision of health care; } \\
1.5 \text { rights to organize labour }\end{array}$ & & $\star$ & $\star$ & $\star$ & $\star$ & & $\mathrm{N}$ \\
\hline ITW A.3.2 & $\begin{array}{l}\text { Forest authority [includes]: } 4 \text {. Authority exists to } \\
\text { implement and control forest management at all levels } \\
\text { with powers and responsibilities legally defined at the } \\
\text { national level. }\end{array}$ & & & $\star$ & $\star$ & $\star$ & & $\mathrm{N}$ \\
\hline ITW A.4.1 & $\begin{array}{l}\text { Forest administration [includes]: } 1 \text {. Forest management } \\
\text { planning is an integral part of the general land use } \\
\text { planning. }\end{array}$ & & & $\star$ & $\star$ & $\star$ & & $\mathrm{N}$ \\
\hline $\begin{array}{l}\text { ITW } \\
\text { A.4.2.3.1 }\end{array}$ & $\begin{array}{l}\text { Research priorities [include]: } 4 \text {. Management of buffer } \\
\text { zones at the interface of agriculture and forestry. }\end{array}$ & & & $\star$ & $\star$ & $\star$ & & $\mathrm{N}$ \\
\hline $\begin{array}{l}\text { ITW } \\
\text { A.4.2.3.2 }\end{array}$ & $\begin{array}{l}\text { Research priorities [include]: } 3 \text {. Research to maximize the } \\
\text { utilization potential of forest products. } 4 \text {. Research into } \\
\text { utilization of currently non-commercial tree species. }\end{array}$ & $\star$ & & & $\star$ & & & $\mathrm{N}$ \\
\hline $\begin{array}{l}\text { ITW } \\
\text { A.4.2.3.5 }\end{array}$ & $\begin{array}{l}\text { Research priorities [include]: } 1 \text {. Methodologies to } \\
\text { evaluate the profitability of different forest management } \\
\text { systems. 2. Rationalization of management processes at } \\
\text { the local level with regard to harvesting, processing, and } \\
\text { pricing of forest products. }\end{array}$ & $\star$ & & & $\star$ & & & $\mathrm{N}, \mathrm{L}$ \\
\hline $\begin{array}{l}\text { ITW } \\
\text { A.4.2.3.5 }\end{array}$ & $\begin{array}{l}\text { Research priorities [include]: 3. Improvement of marketing } \\
\text { strategies for forest products (especially timber). } \\
\text { 6. Cradle to grave environmental evaluation of the } \\
\text { processing of forest products, including energy consumed } \\
\text { in processing. }\end{array}$ & $\star$ & & $\star$ & $\star$ & & & $\mathrm{N}$ \\
\hline ITW B.3.1 & Legally documented rights of settlement. & $\star$ & & $\star$ & $\star$ & $\star$ & & $\mathrm{R}$ \\
\hline ITW B.3.1 & $\begin{array}{l}\text { Legally documented rights of access to and harvesting of } \\
\text { forest products. }\end{array}$ & $\star$ & $\star$ & $\star$ & $\star$ & $\star$ & & $\mathrm{R}$ \\
\hline ITW B.3.1 & Participation in forest management through employment. & & $\star$ & $\star$ & $\star$ & & & $\mathrm{R}$ \\
\hline ITW B.3.10 & $\begin{array}{l}\text { Regional forest administration capability exits for } \\
\text { (1.1) boundary enforcement. }\end{array}$ & & & $\star$ & $\star$ & $\star$ & & $\mathrm{R}$ \\
\hline ITW B.3.11 & $\begin{array}{l}\text { Incentives for sustainable forest management include: } \\
\text { 1. Penalties apply in case of breach of contract. }\end{array}$ & & & $\star$ & $\star$ & $\star$ & & $\mathrm{R}$ \\
\hline ITW C.1.2 & $\begin{array}{l}\text { The contract period is long enough to justify commercial } \\
\text { investment in SFM. }\end{array}$ & $\star$ & & $\star$ & $\star$ & & $\star$ & $\mathrm{L}$ \\
\hline ITW C.1.9 & $\begin{array}{l}\text { Data are available for the whole management unit on } \\
\text { timber growing stock and timber harvest volume. }\end{array}$ & $\star$ & & & $\star$ & $\star$ & & $\mathrm{L}$ \\
\hline ITW C.2.3 & $\begin{array}{l}\text { Data about volume increment in harvested areas by: } \\
\text { compartment, species, diameter class. }\end{array}$ & $\star$ & & $\star$ & $\star$ & $\star$ & & $\mathrm{L}$ \\
\hline ITW C.2.4 & $\begin{array}{l}\text { Planning of AAC. The calculation of AAC is correct and } \\
\text { easily verifiable. }\end{array}$ & $\star$ & & $\star$ & $\star$ & $\star$ & & $\mathrm{L}$ \\
\hline
\end{tabular}


Table B.4. (con'd) Economic Dimensions of C\&I Set - Iniative Tropenwald

\begin{tabular}{|c|c|c|c|c|c|c|c|c|}
\hline \multirow[b]{2}{*}{ Source } & \multirow[b]{2}{*}{ Criterion or Indicator } & \multicolumn{3}{|c|}{ Goal } & \multicolumn{3}{|c|}{$\begin{array}{l}\text { Intervention } \\
\text { Point }\end{array}$} & \multirow{2}{*}{ 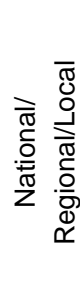 } \\
\hline & & 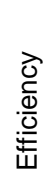 & 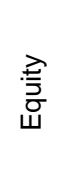 & 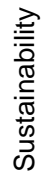 & $\begin{array}{l}\text { O } \\
\frac{\pi}{\pi} \\
\text { c }\end{array}$ & 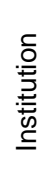 & $\frac{\bar{o}}{\mathrm{O}}$ & \\
\hline ITW C.3.3 & $\begin{array}{l}\text { The guidelines for logging and log transport aim at } \\
\text { minimization of environmental damage and residues, and } \\
\text { at leaving a productive residual stand. }\end{array}$ & $\star$ & & & $\star$ & $\star$ & & $\mathrm{L}$ \\
\hline ITW C.4.1 & $\begin{array}{l}\text { Control measures. 3. Existence of effective protection } \\
\text { measures to prevent illegal encroachment upon the } \\
\text { management unit against: re-entry; illegal logging, fire, } \\
\text { grazing, clearing for farming and settlement. }\end{array}$ & & & $\star$ & $\star$ & $\star$ & & $\mathrm{L}$ \\
\hline ITW C.4.2 & $\begin{array}{l}\text { Control measures. 2. Periodic correction of AAC in case } \\
\text { of over- or under-cutting. }\end{array}$ & $\star$ & & $\star$ & $\star$ & $\star$ & & $\mathrm{L}$ \\
\hline ITW C.4.5 & $\begin{array}{l}\text { Violations of the management company's contractual } \\
\text { obligations are punished. } 4 \text {. Existence of performance } \\
\text { bond/security deposit/advance tax payment or similar } \\
\text { guarantee of good management. }\end{array}$ & & & $\star$ & $\star$ & $\star$ & & $\mathrm{L}$ \\
\hline
\end{tabular}


Table B.5. Economic Dimensions of C\&I Set - Woodmark

\begin{tabular}{|c|c|c|c|c|c|c|c|c|}
\hline \multirow[b]{2}{*}{ Source } & \multirow[b]{2}{*}{ Criterion or Indicator } & \multicolumn{3}{|c|}{ Goal } & \multicolumn{3}{|c|}{$\begin{array}{l}\text { Intervention } \\
\text { Point }\end{array}$} & \multirow{2}{*}{ 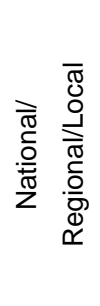 } \\
\hline & & 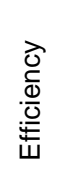 & 胥 & 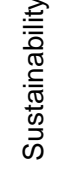 & $\frac{\bar{c}}{\frac{\pi}{\omega}}$ & 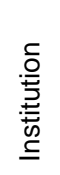 & $\frac{.0}{0}$ & \\
\hline WM 6.101 & $\begin{array}{l}\text { All harvesting must be in accordance with a long term } \\
\text { harvesting plan ... The harvesting plan must ensure that } \\
\text { the ability of the forest to produce a sustained yield is not } \\
\text { impaired. It should aim to diversify the forest ... }\end{array}$ & $\star$ & & & $\star$ & $\star$ & & L \\
\hline WM 6.106 & $\begin{array}{l}\text { The harvesting plan must specify areas, species, tree } \\
\text { sizes, limits, volumes, coupe size, spacing and location. } \\
\text { Where existing data are insufficient these limits should be } \\
\text { conservatively met. }\end{array}$ & $\star$ & & & $\star$ & $\star$ & & L \\
\hline WM 7.103 & $\begin{array}{l}\text { Customary use rights to the forest area - such as rights } \\
\text { of way, use of common land and usufructary rights - must } \\
\text { be respected and upheld. }\end{array}$ & & $\star$ & $\star$ & $\star$ & $\star$ & & L \\
\hline WM 8.301 & $\begin{array}{l}\text { Employees must have the right to organise; i.e.., join } \\
\text { trades unions and undertake collective negotiations } \\
\text { regarding employment terms and conditions. }\end{array}$ & & $\star$ & & $\star$ & $\star$ & & L \\
\hline WM 8.401 & $\begin{array}{l}\text { Forestry operations must be managed in such a way that } \\
\text { they aim to increase the opportunities for economic } \\
\text { activities among local people. }\end{array}$ & & $\star$ & & $\star$ & & & L \\
\hline WM 9.0 & $\begin{array}{l}\text { Forest management encourages an optimal and efficient } \\
\text { use of all forest products and services, in order to ensure } \\
\text { a wide range of environmental, social and economic } \\
\text { benefits. }\end{array}$ & $\star$ & $\star$ & $\star$ & $\star$ & $\star$ & $\star$ & L \\
\hline WM 9.101 & $\begin{array}{l}\text { Information must be available on the range of the forest's } \\
\text { potential products and services, including the role of } \\
\text { forest products in the local, regional, national and } \\
\text { international economies. }\end{array}$ & $\star$ & $\star$ & $\star$ & $\star$ & $\star$ & $\star$ & L \\
\hline WM 9.102 & $\begin{array}{l}\text { Forestry operations must not significantly reduce the } \\
\text { value derived locally from all forest products and services. }\end{array}$ & $\star$ & $\star$ & $\star$ & $\star$ & & & L \\
\hline WM 9.103 & $\begin{array}{l}\text { Forest managers must aim to minimise waste associated } \\
\text { with harvesting and reduce damage to other forest }\end{array}$ & $\star$ & & & $\star$ & & & L \\
\hline WM 9.104 & $\begin{array}{l}\text { Forest management must aim to strengthen and diversify } \\
\text { the local economy, avoiding dependence on a single } \\
\text { forest commodity. }\end{array}$ & $\star$ & & $\star$ & $\star$ & & & L \\
\hline WM 9.105 & $\begin{array}{l}\text { Recommended: a) Cost-benefit evaluations of particular } \\
\text { production activities, should be undertaken where } \\
\text { sufficient information is available. }\end{array}$ & $\star$ & & & $\star$ & & & L \\
\hline WM 9.105 & $\begin{array}{l}\text { Recommended: b) Where appropriate, efficient } \\
\text { processing operations should be established to increase } \\
\text { added-value as locally as possible. Such processing } \\
\text { operations should eventually be financially self- } \\
\text { sustaining. }\end{array}$ & $\star$ & & & $\star$ & & $\star$ & L \\
\hline
\end{tabular}


Table B.6. Economic Dimensions of C\&I Set - SmartWood

\begin{tabular}{|c|c|c|c|c|c|c|c|c|}
\hline \multirow[b]{2}{*}{ Source } & \multirow[b]{2}{*}{ Criterion or Indicator } & \multicolumn{3}{|c|}{ Goal } & \multicolumn{3}{|c|}{$\begin{array}{l}\text { Intervention } \\
\text { Point }\end{array}$} & \multirow{2}{*}{ 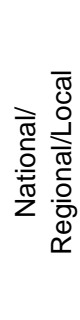 } \\
\hline & & 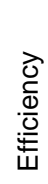 & 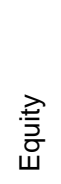 & 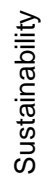 & 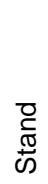 & 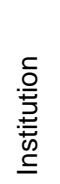 & $\frac{\grave{0}}{\overline{0}}$ & \\
\hline SW 2.1 & Land tenure is clear and legally secure. & & & $\star$ & $\star$ & $\star$ & $\star$ & L \\
\hline SW 2.2 & Land is dedicated by owners to long-term management. & $\star$ & & $\star$ & $\star$ & & & L \\
\hline SW 4.2 & $\begin{array}{l}\text { Annual allowable cut (AAC), by area or volume, has been } \\
\text { set based on conservative and well-documented } \\
\text { estimates of growth and yield. }\end{array}$ & $\star$ & & $\star$ & $\star$ & & & $\mathrm{L}$ \\
\hline SW 4.3 & AAC is being followed in the forest. & $\star$ & & $\star$ & $\star$ & & & $\mathrm{L}$ \\
\hline SW 4.4 & $\begin{array}{l}\text { Silviculture prescriptions (pre-, during, and post-harvest) } \\
\text { are being adhered to. }\end{array}$ & $\star$ & & $\star$ & $\star$ & & & L \\
\hline SW 4.5 & $\begin{array}{l}\text { Growth rates, stocking, and regeneration are being } \\
\text { monitored by a suitable continuous forest inventory } \\
\text { system. }\end{array}$ & $\star$ & & $\star$ & $\star$ & $\star$ & & $\mathrm{L}$ \\
\hline SW 4.6 & $\begin{array}{l}\text { Actions to ensure quantity and quality of future crop, } \\
\text { through either natural or planted regeneration, are being } \\
\text { implemented. }\end{array}$ & $\star$ & & $\star$ & $\star$ & $\star$ & & $\mathrm{L}$ \\
\hline SW 4.7 & $\begin{array}{l}\text { Post-logging assessments take place to assess the } \\
\text { impact of harvesting on future crop trees and the forest, } \\
\text { preferably within } 12 \text { months after harvesting. }\end{array}$ & $\star$ & & $\star$ & $\star$ & $\star$ & & $\mathrm{L}$ \\
\hline SW 5.21 & $\begin{array}{l}\text { In-migration, settlement, hunting, and timber extraction } \\
\text { along logging roads is controlled. }\end{array}$ & & & $\star$ & $\star$ & $\star$ & & L \\
\hline SW 7.1 & $\begin{array}{l}\text { Wages and other benefits (health, retirement, worker's } \\
\text { compensation, housing, food) are fair and consistent with } \\
\text { (not lower than) prevailing local standards. }\end{array}$ & & $\star$ & & $\star$ & & & L \\
\hline SW 7.2 & $\begin{array}{l}\text { Worker safety is considered and conditions are fair and } \\
\text { consistent with local norms (not a higher than normal } \\
\text { accident rate.) }\end{array}$ & & $\star$ & & $\star$ & & & L \\
\hline SW 8.1 & $\begin{array}{l}\text { Stumpage rates or other rents being paid to landholders } \\
\text { are at or above the norm (i.e., average), and are } \\
\text { perceived by landowners to be a positive incentive for } \\
\text { encouraging long term forest management. }\end{array}$ & $\star$ & & $\star$ & $\star$ & & $\star$ & L \\
\hline SW 8.2 & $\begin{array}{l}\text { Stumpage paid is sufficient to cover costs of maintaining } \\
\text { land as forest. }\end{array}$ & $\star$ & & $\star$ & $\star$ & & $\star$ & L \\
\hline SW 8.3 & $\begin{array}{l}\text { Revenue received is sufficient to financially support post- } \\
\text { harvest management activities such as road } \\
\text { maintenance, silviculture treatments, and long-term forest } \\
\text { health and growth and yield monitoring. }\end{array}$ & $\star$ & & $\star$ & $\star$ & & $\star$ & $\mathrm{L}$ \\
\hline
\end{tabular}


Table B.7. Economic Dimensions of C\&I Set - Lembaga Ekolabel Indonesia

\begin{tabular}{|c|c|c|c|c|c|c|c|c|}
\hline \multirow[b]{2}{*}{ Source } & \multirow[b]{2}{*}{ Criterion or Indicator } & \multicolumn{3}{|c|}{ Goal } & \multicolumn{3}{|c|}{$\begin{array}{l}\text { Intervention } \\
\text { Point }\end{array}$} & \multirow{2}{*}{ 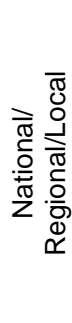 } \\
\hline & & 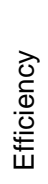 & 禀 & 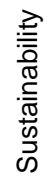 & $\begin{array}{l}\text { O } \\
\frac{\pi}{\infty} \\
\frac{\pi}{\omega}\end{array}$ & 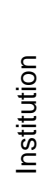 & $\frac{. \bar{े}}{\circ}$ & \\
\hline LEI 34 & $\begin{array}{l}\text { Exploitation factor to measure intensity of logging } \\
\text { (depends on the physical condition of the land and the } \\
\text { types of wood exploited). }\end{array}$ & $\star$ & & $\star$ & $\star$ & & & L \\
\hline LEI 35 & $\begin{array}{l}\text { Ratio between the main and side roads to the size of the } \\
\text { forest (to judge "efficiency rate of logging transport"). }\end{array}$ & $\star$ & & & $\star$ & & & $\mathrm{L}$ \\
\hline LEI 36 & $\begin{array}{l}\text { Whether the quality of the road is proportional to the } \\
\text { potential of the forest (to get knowledge of logging-related } \\
\text { transport activities). }\end{array}$ & $\star$ & & & $\star$ & & & L \\
\hline LEI 37 & $\begin{array}{l}\text { Frequency of extraction of non-wood resources, classified } \\
\text { by types and groups of people who extract them. }\end{array}$ & $\star$ & $\star$ & & $\star$ & & & $\mathrm{L}$ \\
\hline LEI 38 & $\begin{array}{l}\text { Volume of non-wood resources, classified by types and } \\
\text { groups of people who extract them. }\end{array}$ & $\star$ & $\star$ & & $\star$ & & & L \\
\hline LEI 39 & $\begin{array}{l}\text { Volume of non-wood resources extracted by the } \\
\text { concessionaire. }\end{array}$ & $\star$ & & & $\star$ & & & L \\
\hline LEI 40 & $\begin{array}{l}\text { Frequency of the concessionaire's extraction of the non- } \\
\text { wood resources. }\end{array}$ & $\star$ & & & $\star$ & & & $\mathrm{L}$ \\
\hline LEI 60 & $\begin{array}{l}\text { System of production - self or contract (to judge "certainty } \\
\text { of monitoring and control of work"). }\end{array}$ & $\star$ & & & $\star$ & & & L \\
\hline LEI 62 & $\begin{array}{l}\text { The ratio of the number and percentage of employees, } \\
\text { classified by educational levels, seniority and functions to } \\
\text { the size of the concession area. }\end{array}$ & $\star$ & $\star$ & & $\star$ & & & L \\
\hline LEI 63 & $\begin{array}{l}\text { The proportion of the employees whose jobs are suitable } \\
\text { to their educational background and/or experience }\end{array}$ & $\star$ & & & $\star$ & & & L \\
\hline LEI 64 & $\begin{array}{l}\text { The proportion of employees who receive wages above } \\
\text { the prevailing local minimum wage. }\end{array}$ & & $\star$ & & $\star$ & & & L \\
\hline LEI 65 & $\begin{array}{l}\text { The proportion of employees who are employed through } \\
\text { the informal channels. }\end{array}$ & & $\star$ & & $\star$ & & & $\mathrm{L}$ \\
\hline LEI 77 & $\begin{array}{l}\text { The percentage of actual to planned amount of } \\
\text { investment and reinvestment costs of forest rehabilitation } \\
\text { efforts. }\end{array}$ & $\star$ & & $\star$ & $\star$ & & & L \\
\hline LEI 78 & $\begin{array}{l}\text { The distribution of actual investments and reinvestments } \\
\text { in the interests of income, conservation of the ecosystem } \\
\text { and socio-cultural aspects. }\end{array}$ & & $\star$ & $\star$ & $\star$ & & & L \\
\hline LEI 79 & $\begin{array}{l}\text { The percentage of actual costs for direct participation in } \\
\text { regional development. }\end{array}$ & & & $\star$ & $\star$ & $\star$ & & $\mathrm{L}$ \\
\hline LEI 80 & $\begin{array}{l}\text { The proportion of actual annual costs allocated to } \\
\text { development of the local community, classified by } \\
\text { activities and targeted groups. }\end{array}$ & & $\star$ & $\star$ & $\star$ & $\star$ & & L \\
\hline LEI 81 & $\begin{array}{l}\text { The proportion of the unit's employees who have the task } \\
\text { of developing the local community, classified by } \\
\text { educational levels, experience and managerial levels. }\end{array}$ & & & $\star$ & $\star$ & $\star$ & & L \\
\hline
\end{tabular}




\section{Acknowledgement}

The authors acknowledge the cooperation of CIFOR, the Forest Stewardship Council, Mexico, and the British Columbia Ministry of Environment, Lands and Parks, Canada, in assisting with information retrieval and research. The authors also gratefully acknowledge comments received from Martine Antona, Neil Byron, Carol Colfer, Chimère Diaw, Alain Karsenty, and Ravi Prabhu on an earlier version of this paper. Any opinions or conclusions expressed herein, however, are those of the authors and do not necessarily reflect the position of these agencies or individuals.

\section{About the Authors}

H.J. Ruttenbeek Resource Consulting Limited (HJRRCL) is a Canadian firm specializing in the economic analysis of natural resource, environmental and human security issues. Its work over the past two decades has spanned projects in North America, Eastern Europe, Asia, Africa, and Latin America \& the Caribbean, for clients that include national governments, international aid and lending agencies, the private sector, and international environmental NGOs.

JACK RUITENBEEK, president of HJRRCL, holds degrees in physics and natural resource economics, as well as a $\mathrm{PhD}$ in development economics from the London School of Economics. His published work deals with environmental economic analysis, and with the modeling of social, ecological and economic indicators. He is a founding member of the Canadian Chapter of the International Society for Ecological Economics, and has served as expert witness to various regulatory commissions and tribunals.

Cynthia CARTIER, economist with HJRRCL, holds a MA degree in development economics from Simon Fraser University, Canada, and has specialized in the economic analysis of energy, forestry and environmental issues. Her work in Canada has focused on issues relating to environmental economic analyses and to environmental institutions, while her international work has focused on valuations and analyses of linkages between the economy, environment and social sectors in developing countries.

The authors may be contacted at: H.J. Ruitenbeek Resource Consulting Limited RR\#2 - Site 52 - C21, Gabriola Island, BC, CANADA V0R 1X0; E-mail: hjruiten@web.net 
